\title{
Assessment of the Red Rock River Subbasin and Wetlands of the Centennial Valley
}

Prepared for:

Bureau of Land Management, Montana / Dakotas State Offices

By:

Linda K. Vance, Karen Newlon, Jessica Clarke and David M. Stagliano

Montana Natural Heritage Program

Natural Resource Information System

Montana State Library

June 2009

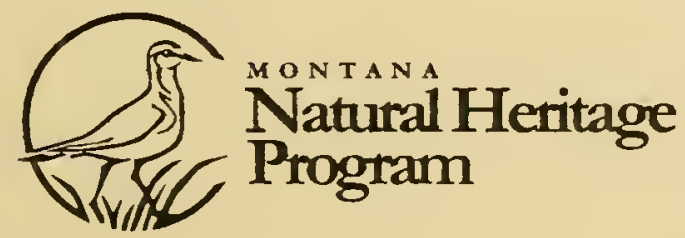




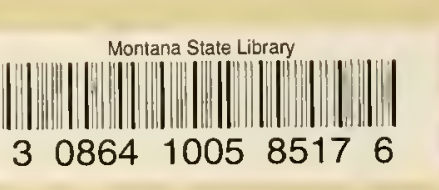




\section{Assessment of the Red Rock River Subbasin and Wetlands of the Centennial Valley}

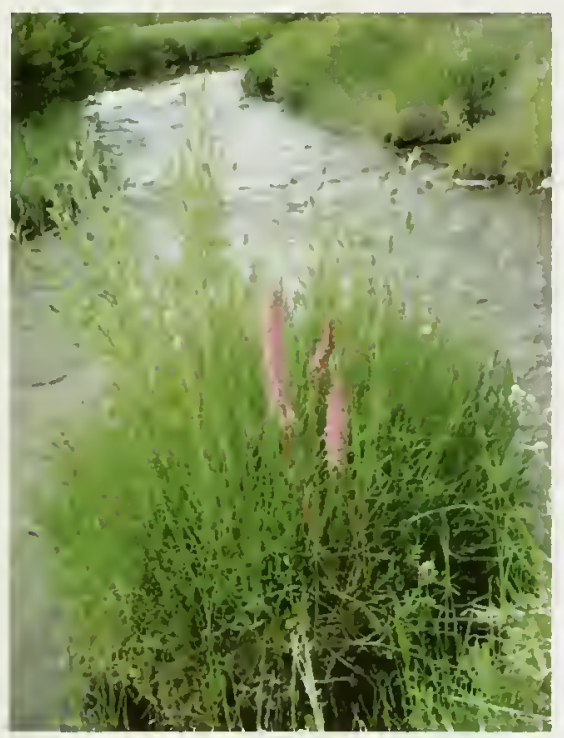

Prepared for:

Bureau of Land Management. Montana / Dakotas State Offices

Agreement Number:

L08AC 14562

By:

Linda K. Vance, Karen Newlon, Jessica Clarke and David M. Stagliano
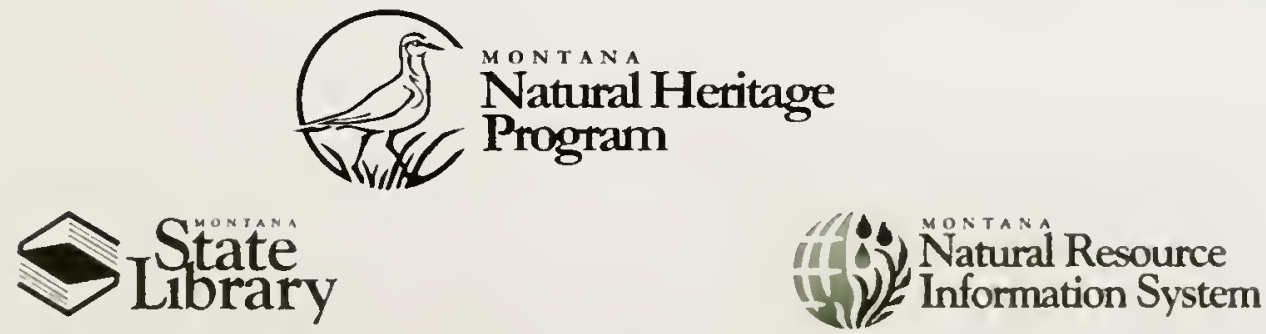

(c) 2009 Montana Natural Heritage Program

P.O. Box 201800 • 1515 East Sixth Avenue • Helena. MT 59620-1800 • 406-444-5354 
This document should be cited as follows:

Vance. Linda K., Karen Newlon, Jessica Clarke and David M. Stagliano. 2009. Assessment of the Red Rock River Subbasin and Wetlands of the Centennial Valley. Report to the Bureau of Land Management, Montana / Dakotas State Offices. Montana Natural Heritage Program. Helena, Montana 43 pp. plus appendices. 


\section{Executive Summary}

This report summarizes results from a multi-scale ecological assessment of fourteen watersheds in the Red Rock River subbasin in southwestern Montana. and an in-depth assessment of wetlands on BLM-managed lands in the Red Rock Creek and Lima Reservoir watersheds of the Centennial Valley. The goal of the project was to provide landscape-level assessments of watershed health and integrity, as well as site-specific evaluations of wetland and aquatic condition, using a probabilistic survey approach. This was accomplished using both broad-scale GIS analysis and field sampling.

The value of watershed-level assessments lies in identifying areas where impacts are currently occurring or may occur, rather than merely documenting effects that have already occurred. By combining both site-level and watershed-level assessments, it is possible to select areas where management can make a substantial difference in future wetland and aquatic health.

Our broad-scale GIS assessment examined underlying biological diversity, measured current conditions, and evaluated potential threats. Several key findings emerged from the GIS data analysis:

- The assessment area lies in a sparselypopulated part of Montana, where most of the land is in public ownership. Across the Red Rock River subbasin area, the BLM Dillon Field Office owns or manages approximately 411,977 acres $(206,497$ hectares). The BLM State Office owns an additional 21.328 acres $(8,631$ hectares) in the Centennial Mountains Wilderness Study Area. Altogether, the BLM has responsibility for 433,305 acres (175,352 hectares) in the Red Rock River subbasin, almost $29 \%$ of the area. The Forest Service is the next largest public land owner, managing 391.924 acres (158.606 hectares). In the two watersheds containing the Centennial Valley (Lima Reservoir and Red Rock Lakes), the BLM owns or manages approximately 106,213 acres (42,983 hectares). The U.S. Fish and Wildlife Service manages almost 100,000 acres $(40,469$ hectares $)$ in these two watersheds, and both the Nature Conservancy and Montana Land Reliance have substantial easements on private lands in the Centennial.

- Across the subbasin as a whole, $45 \%$ of the land cover is grassland, $31 \%$ is shrubland, $17 \%$ is forest, and $4 \%$ is agriculture. Wetlands make up less than $2 \%$ of the land cover. In the Centennial Valley, $35 \%$ of the land cover is grassland. $37 \%$ is shrubland. $16 \%$ is forest. $8 \%$ is wetland and $2.5 \%$ is open water. Throughout the subbasin, both public and private grasslands and shrublands are used primarily for cattle grazing.

- In terms of hydrology, topography, and vegetation communities, the Red Rock Lakes 5th code hydrologic unit has the most complexity of the watersheds we evaluated, while the Muddy Creek 5 th code hydrologic unit has the least.

- Watershed condition, as measured by a broad landscape integrity index and a separate stream corridor integrity index, was relatively high. The Red Rock Lake 5th code hydrologic unit had the highest score on our Composite Watershed Integrity Index, while Lower Horse Prairie Creek had the lowest score. These indices are based on the amount and density of landscape level disturbances (roads, stream diversions, mines, etc.), and do not necessarily reflect site-specific impacts. However, landscape disturbance is often correlated with sitespecific disturbance. For example, in the Lower Horse Prairie Creek watershed, floodplains have been altered by agriculture and associated water extraction.

- The primary human-caused threat to wetland and watershed integrity in the subbasin as a whole is riparian grazing. The highest potential threat is in the Lima Reservoir watershed, where most streams and waterbodies are on land used primarily for grazing. However, this potential threat can be offset by proper grazing management practices. 
Our fine-scale assessments focused on wetlands and streams in the Red Rock Lakes and Lima Reservoir watersheds in the Centennial Valley. We conducted Proper Functioning Condition (PFC) assessments at 103 lentic and lotic sites, and found:

- 74 in Proper Functioning Condition;

- 19 Functional at Risk witl a downward trend;

- 3 Functional at Risk with an undetermined trend:

- 7 Nonfunctional

All lotic sites sampled (8) were in Proper Functioning Condition.

Of 83 sampling sites on or immediately adjacent to BLM-managed lands, we found:

- 56 in Proper Functioning Condition with a stable trend;

- 17 Functional at Risk with a downward trend;

- 3 Functional at Risk with an undetermined trend:

- 7 Nonfunctional.

We also carried out aquatic assessments at 37 sites using macroinvertebrate-based metrics. Because the streams in the Centennial Valley exhibited characteristics of both foothill-valley streams and mountain streams, we used two multimetric indices to interpret our findings. With the Montana DEQ's Foothill-Valley index, 15 of the 16 lotic sites sampled were ranked non-impaired (good to excellent biological integrity) and 1 was slightly impaired. Using the DEQ Mountain index, 6 of 15 were nonimpaired, 5 slightly impaired and 4 moderately to severely impaired. In both cases, the macroinvertebrate index scores showed little correlation with riparian and instream habitat assessments.

The best opportunities for wetland protection in the Centennial Valley involve grazing management. Upland condition in the Centennial Valley indicates that good grazing practices are the norm. We suggest two specific strategies for wetlands: identification of clusters of high-quality or restorable fens and/or carrs where exclusion could be an option. and identification of areas with high concentrations of seasonally flooded wetlands, where seasonality of grazing could be adjusted to prevent damage to wet soils. 


\section{ACKNOWLEDGements}

We would like to thank the Montana State Office of the Bureau of Land Management, especially Mike Philbin, for funding assistance for the overall watershed assessment. Our work benefited from the field assistance of Coburn Currier. Natalie Byars, and Cat McIntyre. Report formatting was provided by Coburn Currier. All photographs were taken by MTNHP personnel unless otherwise noted. 


\section{Table of Contents}

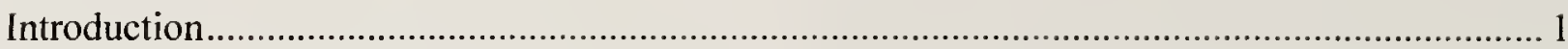

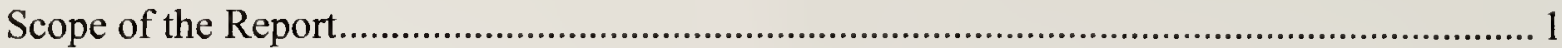

The Ecological Setting: Level III and IV Ecoregions......................................................... 1

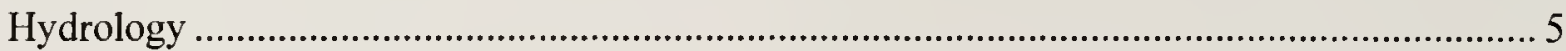

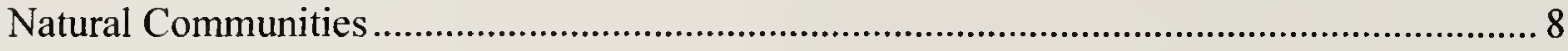

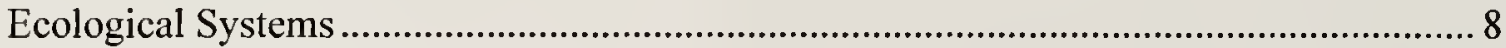

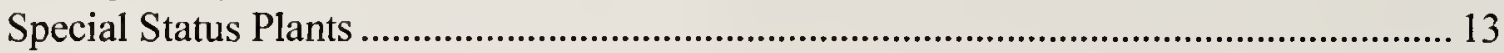

Wildlife and Fish.................................................................................................. 13

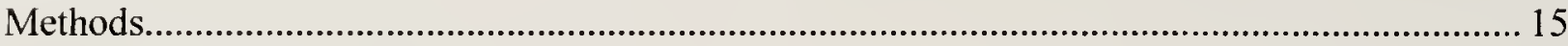

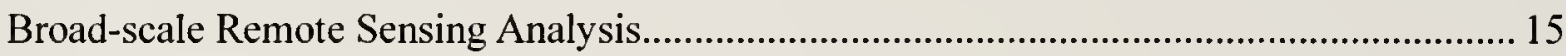

Natural Complexity Index.................................................................................... 15

Composite Wetland Condition Index.......................................................................... 15

Composite Riparian Threat Index ............................................................................. 16

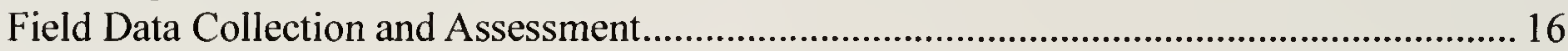

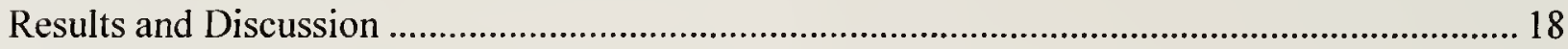

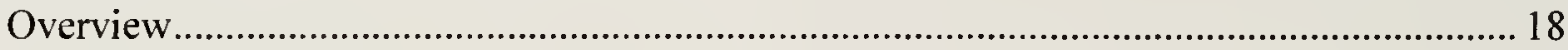

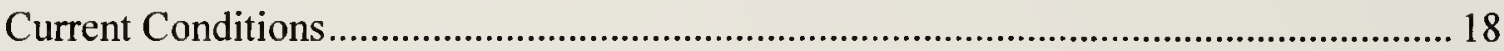

Factors and Magnitude of Change ............................................................................. 18

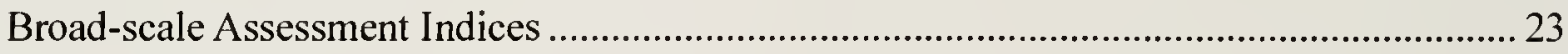

Composite Natural Complexity Index ............................................................................ 23

Composite Watershed Condition Index ………………................................................2 26

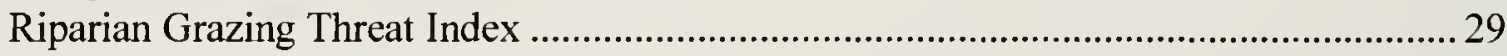

Interpreting the Broad-scale Assessment Composite Indices ................................................ 31

Fine-scale Assessments....................................................................................................... 31

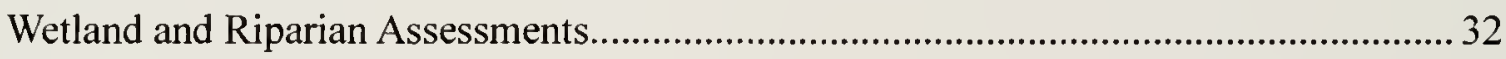

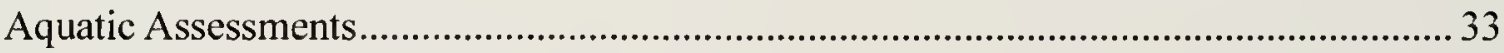

Relationship Between Broad-scale and Fine-scale Assessments ............................................... 36

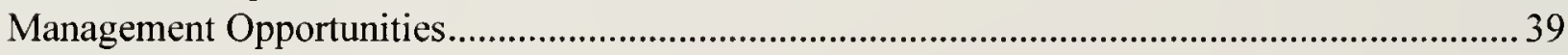

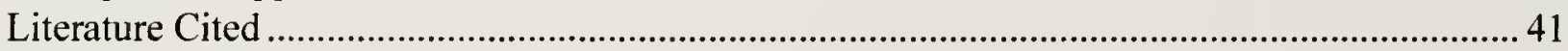

Appendix A. Montana Species of Concern in the Assessment Area

Appendix B. MTNHP Rapid Ecological Integrity Assessment Forms

Appendix C-1. Site Information. Wetland Assessment

Appendix C-2. PFC and EIA Scores

Appendix C-3. Site Comments

Appendix D. Species Richness at BLM Sites

\section{List OF Figures}

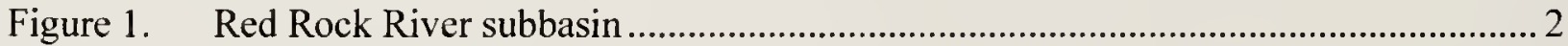

Figure 2. Level IV ecoregions of the Red Rock River subbasin .......................................... 3

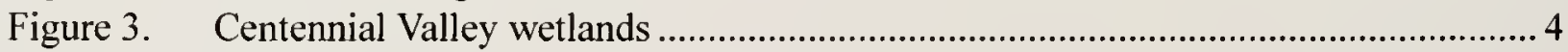

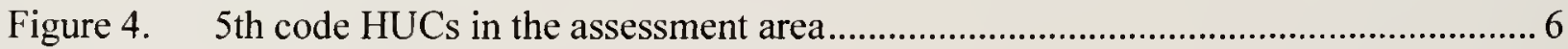




\section{List OF Figures (CON'T)}

Figure 5. Ecological systems in the assessment area....................................................... 10

Figure 6. Centennial Valley sampling locations .............................................................. 17

Figure 7. Land stewardship, Red Rock Subbasin ................................................................. 19

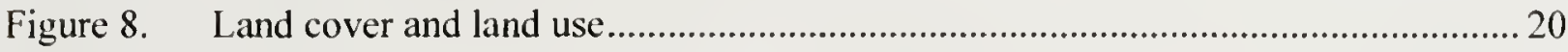

Figure 9. Hydrographs for Red Rock River gauging stations, 2000-2008 ...........................2 21

Figure 10. Pugging and hummocking in a Centennial Valley wetland.................................22-23

Figure 11. Composite Watershed Condition Index score ............................................................. 30

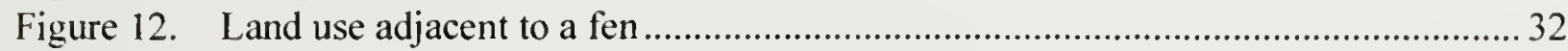

Figure 13. A proper functioning condition riparian site ............................................................. 33

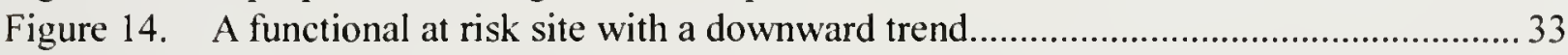

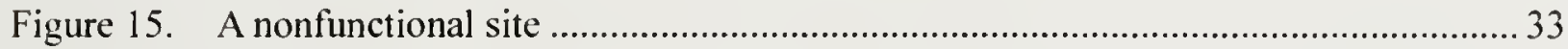

Figure 16. MMI scores vs. BLM habitat scores (functional condition) ………….....................36

Figure 17. Odonata larval species richness by functional condition ........................................... 37

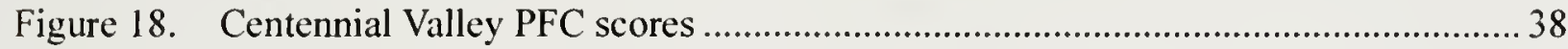

Figure 19. Centennial Valley saturated wetlands..................................................................... 40

\section{LIST OF TABLES}

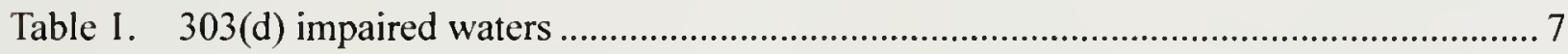

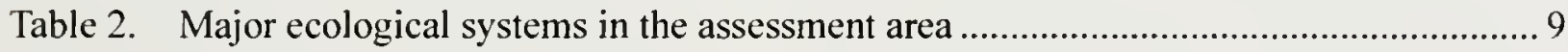

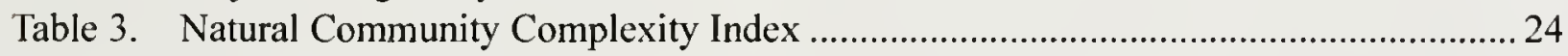

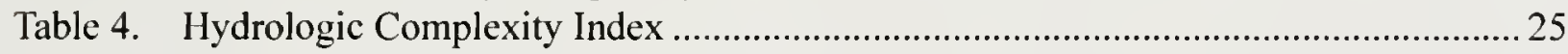

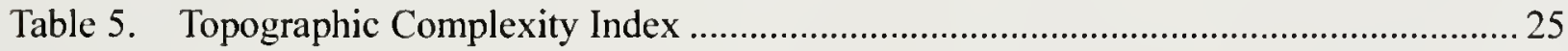

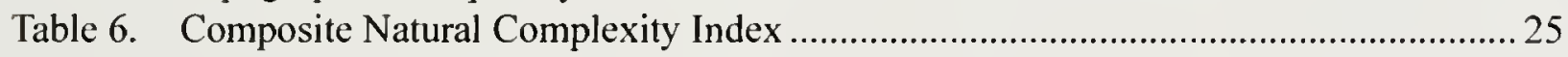

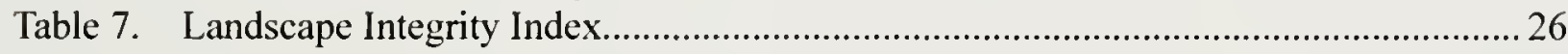

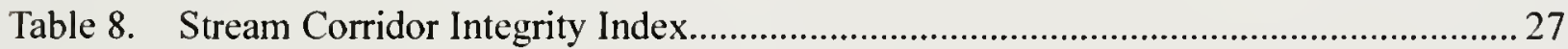

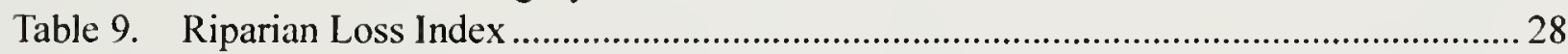

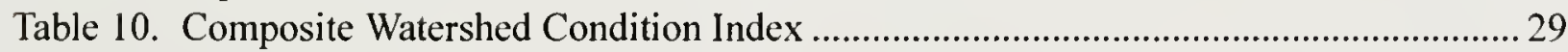

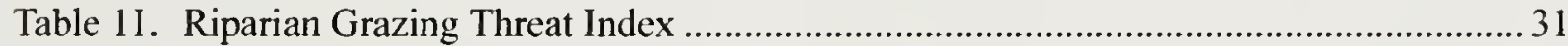

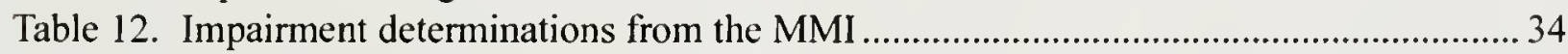

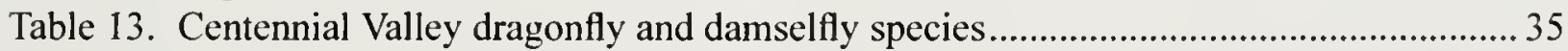




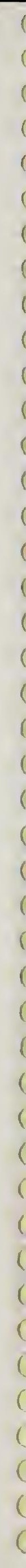




\section{INTRODUCTION}

\section{Scope of the Report}

This assessment covers fourteen 5 th code hydrologic units (HUCs) or watersheds' (Figure I) encompassing roughly 1.5 million acres $(600,000$ hectares) in Beaverhead and Madison counties in southwestern Montana The watersheds are all part of the Red Rock River subbasin (4th code HUC) that drains into the Beaverhead River, a tributary of the Jefferson River, and ultimately, the Missouri.

The goal of this project was to provide site-specific evaluations of riparian areas, wetlands, and aquatic resources under the jurisdiction of the Bureau of Land Management (BLM) in the Centennial Valley, and a broad GIS-based assessment of the Red Rock River subbasin. Field sampling of wetland and aquatic sites provided detailed information on the composition and distribution of plant and invertebrate communities in sites under BLM management. We conducted a broad GIS analysis to evaluate watershed condition across the contributing watersheds. using indices of watershed integrity developed in earlier watershed assessments (Vance and Stagliano 2007, 2008).

\section{The Ecological Setting: Level III and IV Ecoregions}

The assessment area lies within the Middle Rockies Level III ecoregion (Omernik 1987). Five Level IV ecoregions dominate: the Barren Mountains; the Centennial Basin: the Dry-Gneissic-SchistoseVolcanic Hills; the Dry Intermontane Sagebrush Valleys; and the Forested Beaverhead Mountains (Figure 2). Small portions of the Western Beaverhead Mountains, the Eastern Gravelly Mountains, and the Alpine Zone occur near the perimeter of the subbasin.

The Barren Mountains ecoregion consists of dry, partially forested slopes with a sparsely grassy understory and barren outcrops, overlaying carbonate-rich sedimentary rock. Douglas-fir (Pseudotsuga menziesii) is the dominant tree species at lower elevations, while subalpine fir (Abies lasiocarpa) is more common above $\mathbf{8 , 0 0 0}$ feet and on north-facing slopes. The shrub layer is generally not well developed. Pinegrass (Calamagrostis rubescens) is the characteristic grass species. Winters are typically cold and long.

The cold, low-relief Centennial Basin is distinctively subirrigated with extensive grasslands, wet and mesic meadows, lakes, shrub carrs, and herbaceous wetlands. Wetlands within the Basin vary from tree-dominated Engelmann spruce (Picea engelmamii) and quaking aspen (Populus tremuloides) habitats to willow-dominated swamps and carrs to emergent herbaceous types such as sedge-dominated marshes and fens. Additionally, subirrigated areas with sodic soils support black greasewood (Sarcobatus vermiculatus), Nuttall's alkaligrass (Puccinellia muttalliana), and inland saltgrass (Distichlis spicata)-dominated communities. Some of the most extensive wetlands are those dominated by hardstem bulrush (Schoenoplectus acutus), baltic rush (Juncus balticus), Northwest Territories sedge (Carex utriculata) and northern reedgrass (Calamagrostis stricta). On the northern edge of the basin, the Centennial Sandhills form a unique regional environment supporting a number of sensitive plant species and rare natural communities. In addition to the stable vegetation comprised of basin big sagebrush (Artemisia tridentata ssp. tridentata), three-tip sagebrush (Artemisia tripartita) and needle-and-thread (Hesperostipa comata) or Idaho fescue (Festuca idahoensis), the Centennial Sandhills include vegetation that depends on active sand dunes and blowouts, such as green rabbitbrush (Chrysothamnus viscidiflorus) and thickspike wheatgrass / silverleaf phacelia (Elymıs lanceolatus / Phacelia hastata) communities.

The shrubby, semi-arid Dry Gneissic-SchistoseVolcanic Hills ecoregion occurs above 4.800 feet, where average annual precipitation is higher than in the dry sagebrush valleys and the basin. Here

\footnotetext{
${ }^{1}$ HUC nomenclalure correspond to common usage as follows: 4th code HUCs are subbasins; 5 th code HUCs are walersheds. and 6 th code HUCs are subwatersheds
} 


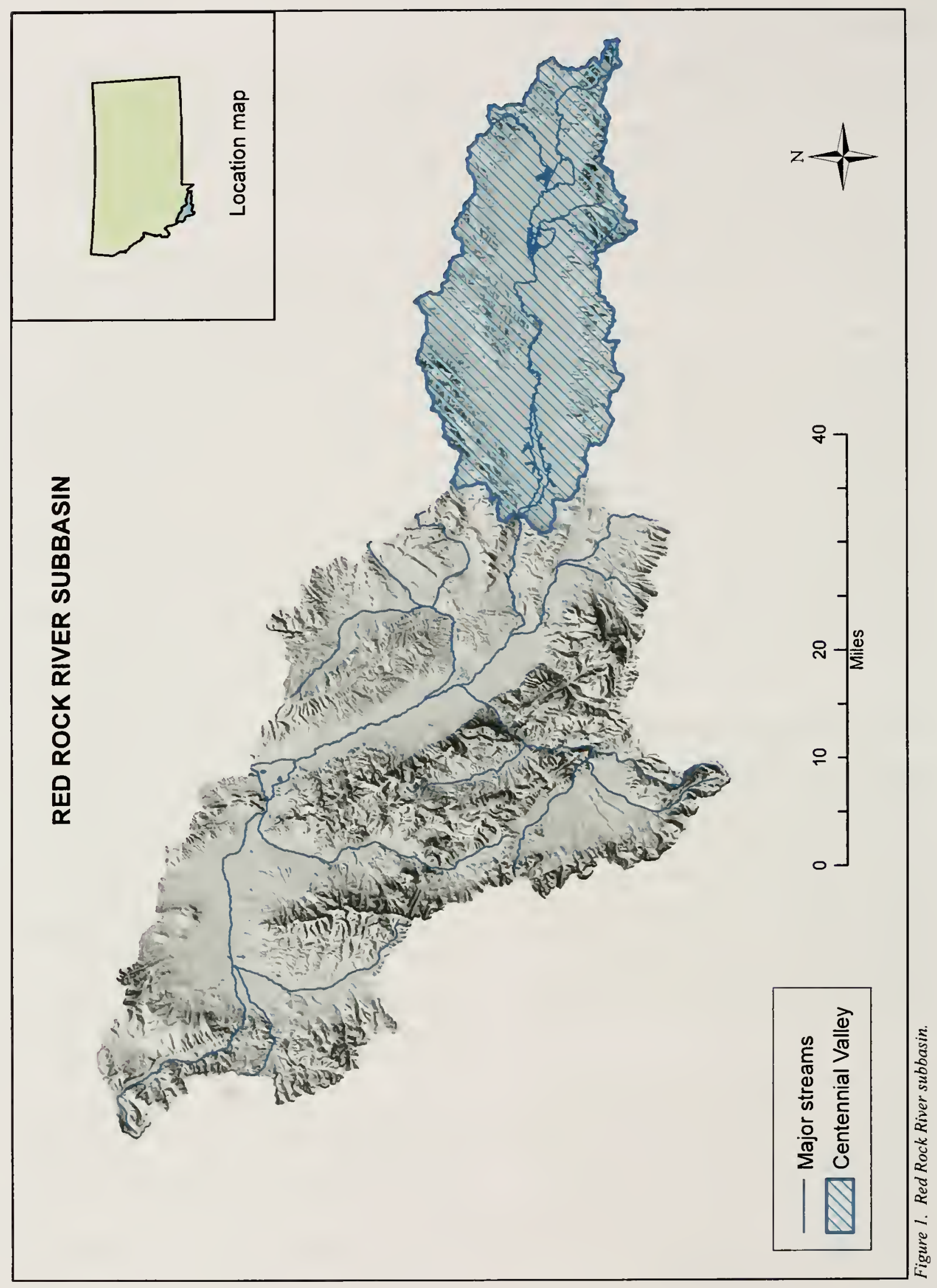




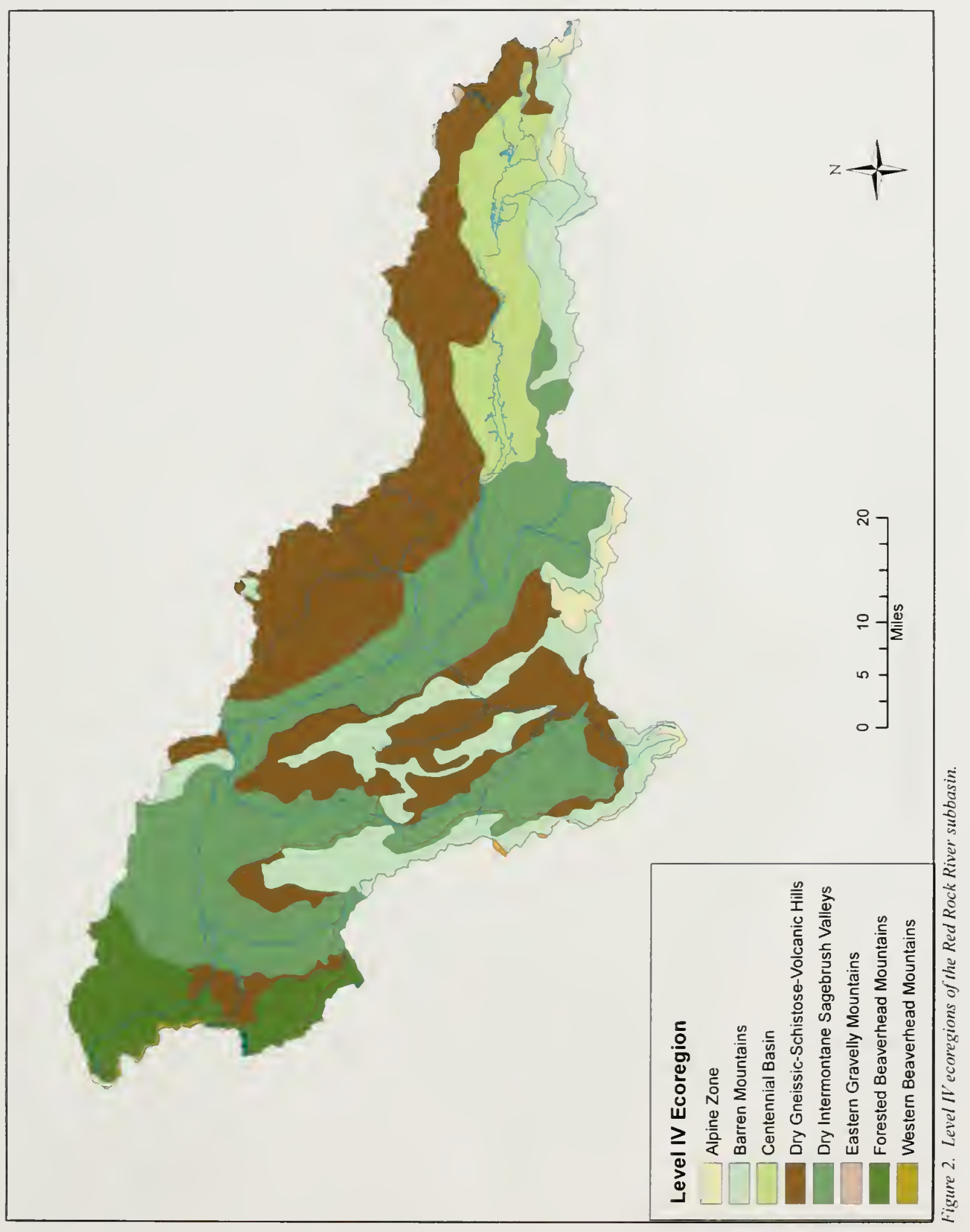




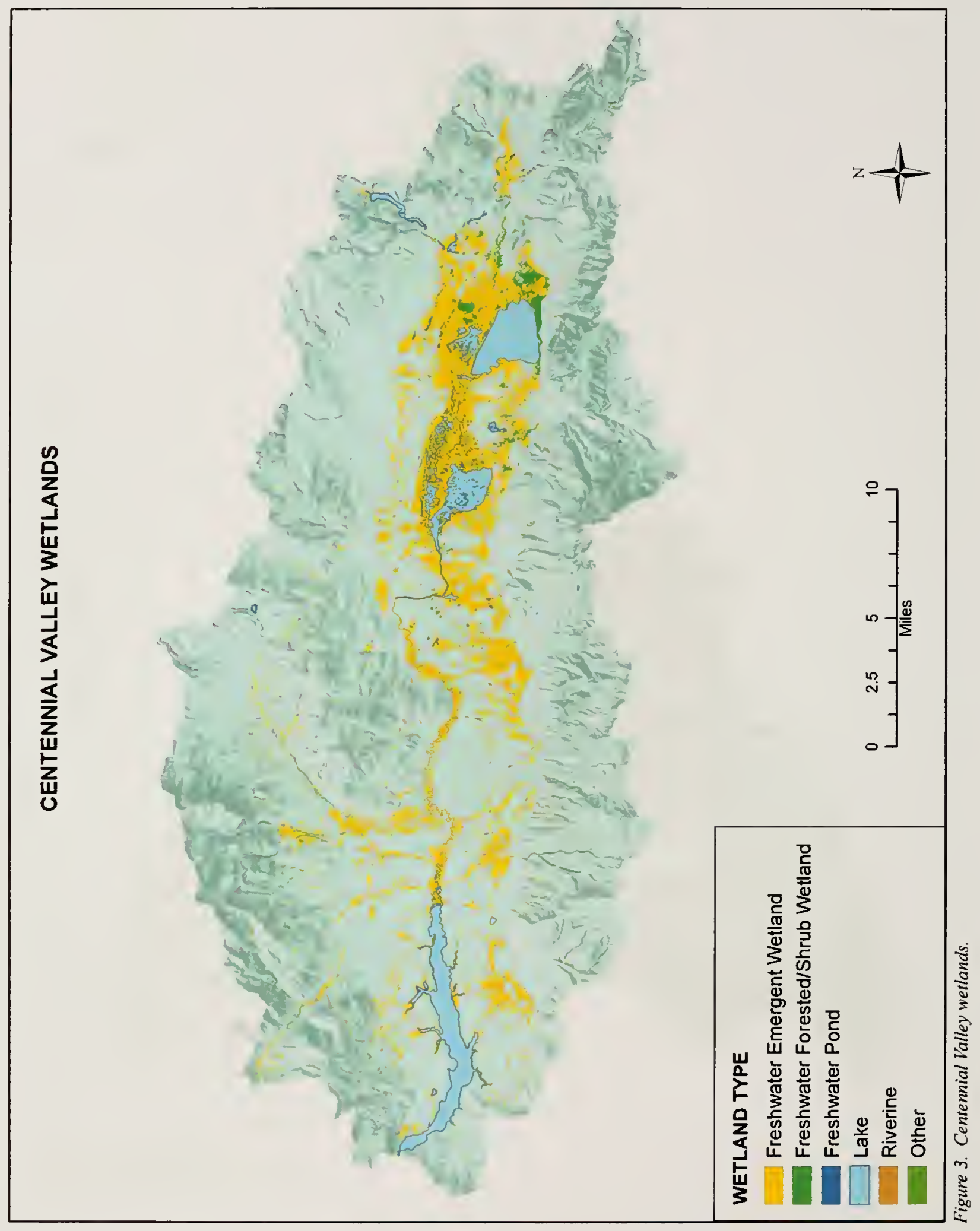


too, vegetation is primarily sagebrush steppe.

Shrub cover can be high for a steppe system due to greater moisture found at mountain elevations: the canopy cover is usually between 20 to 80 percent. The herbaceous layer is usually well represented, but bare ground may be common in particularly arid or disturbed occurrences.

\section{The Dry Intermontane Sagebrush Valley} ecoregion occurs on stream terraces, fans, and floodplains mostly composed of alluvium and valley fill deposits. The vegetation is primarily sagebrush steppe, dominated by mountain big sagebrush (Artemisia tridentata ssp. vaseyana) and ldaho fescue and related taxa such as basin big sagebrush and three tip sagebrush. Antelope bitterbrush (Purshia tridentata) may codominate or even dominate some stands. Most stands have an abundant perennial herbaceous layer (over $25 \%$ cover, in many cases over $50 \%$ cover). The growing season is typically short (70 to 110 days), although it is longer than in the low-lying Centennial Basin.

The glaciated Forested Beaverhead Mountains are characterized by gentle lower slopes, pothole lakes, and marshy areas. Average annual precipitation ranges from 20 to just over 40 inches. Underlying geology is composed of Precambrian argillite, quartzite, carbonates, and shales. At the lower treeline immediately above valley grasslands or sagebrush steppe and shrublands, vegetation includes extensive Douglas-fir forests, occasionally mixed with limber pine (Pimus flexilis) on calcareous substrates, and lodgepole pine (Pinus contorta) at higher elevations. In the upper montane and subalpine zones, Engelmann spruce appears. Subalpine areas are dominated by Engelmann spruce and subalpine fir.

\section{Hydrology}

The Red Rock River subbasin includes fourteen 5 th code HUCs (Figure 4), with streams and rivers that drain into the Beaverhead River. The longest of these is Red Rock River, formed by Odell and Hellroaring Creeks, which originate on the north flank of the Centennial Mountains. Horse Prairie Creek, Sheep Creek, and Medicine Lodge Creek drain the western mountains. The National
Hydrography Dataset (NHD) shows 1,573 miles of perennial streams and rivers in the assessment area. and 4.315 miles of intermittent streams and rivers. The Lima Reservoir and Red Rock Lakes 5th code HUCs have the most perennial stream miles; the Bloody Dick Creck and Red Rock Lakes HUCs have the highest density of perennial streams and creeks per square mile of watershed.

There are 1.579 lakes, pond, and reservoirs in the assessment area. Of these, 1,133 are in the Red Rock Lakes and Lima Reservoir watersheds. Many are shallow, and most lower-elevation water bodies have been created or enhanced by human structures. For example, Upper and Lower Red Rock Lakes are remnants of more extensive ancestral lakes that formed in the pluvial climates of the Pleistocene and early Holocene epochs. Current depth is approximately 8 feet. Although there is a water control structure on Lower Red Rock Lake, it has been open for several years, allowing water to flow through. Downstream from the lakes, the Red Rock River flows into the 4,422 acre Lima Reservoir, one of the major irrigation reservoirs in Montana.

Several streams and reservoirs in the assessment area are on Montana s 2006 list of waters that are impaired within the meaning of section 303(d) of the Clean Water Act. The beneficial uses that are most frequently impaired are aquatic life and coldwater fisheries. Table 1 lists the water bodies on the 2006303 (d) list and the pollutant(s) underlying the impairment.

Wetland mapping is only complete for portions of the Lima Reservoir and Red Rock Lakes watersheds, the part of the study area where wetlands are most abundant. The National Wetlands Inventory shows some 5.675 wetlands in the Centennial Valley and surrounding hills. Of these, 3,467 are herbaceous emergent wetlands (32,567 acres), 1,487 are aquatic bed wetlands associated with lakes and ponds ( 12,185 acres), 565 are forested or scrub-shrub wetlands (2,356 acres). The remaining 156 wetlands are riverine wetlands along the banks of perennial rivers, or seasonally flooded, sparsely vegetated basins. Riparian shrub communities that are not wet enough to be mapped 


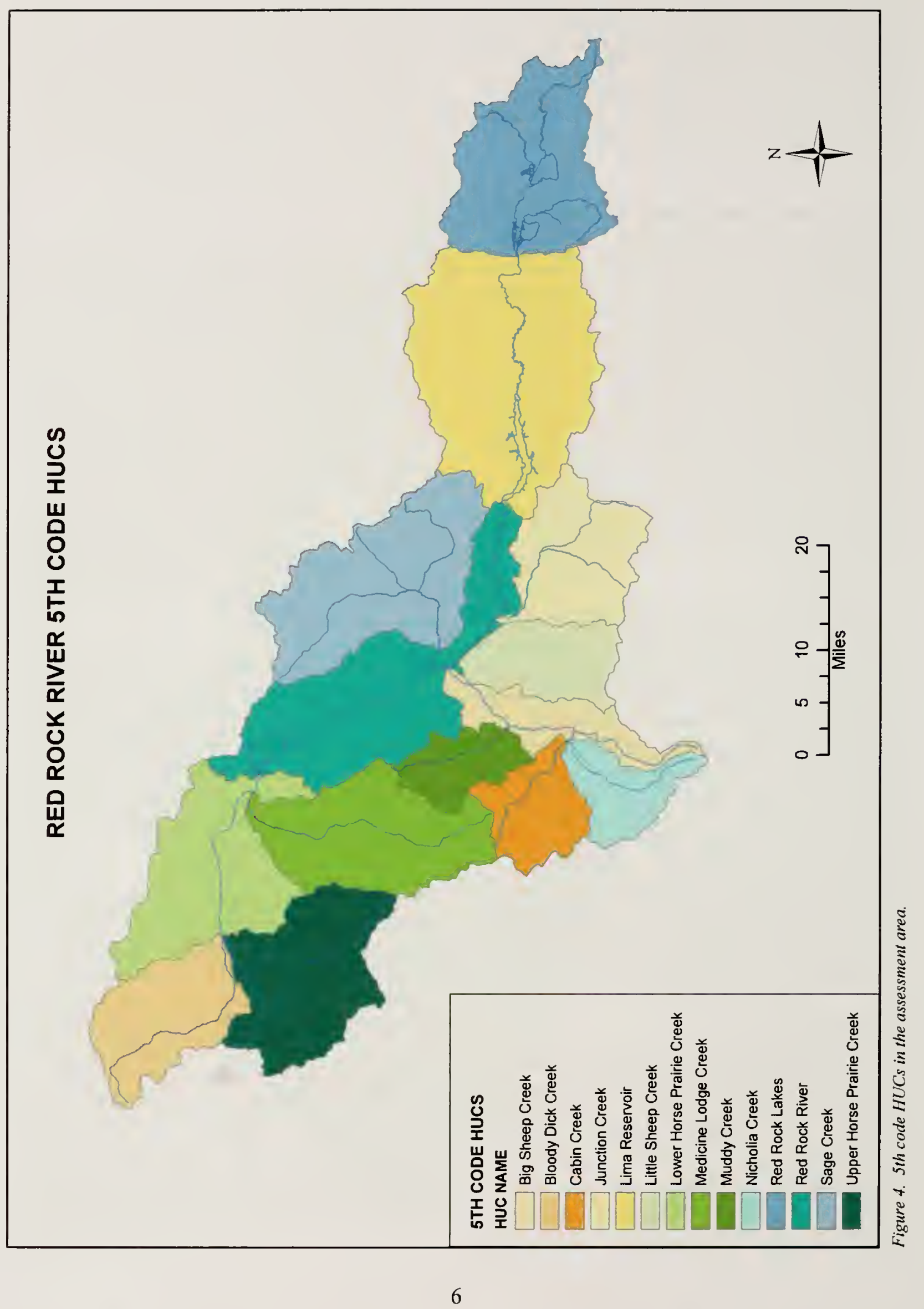




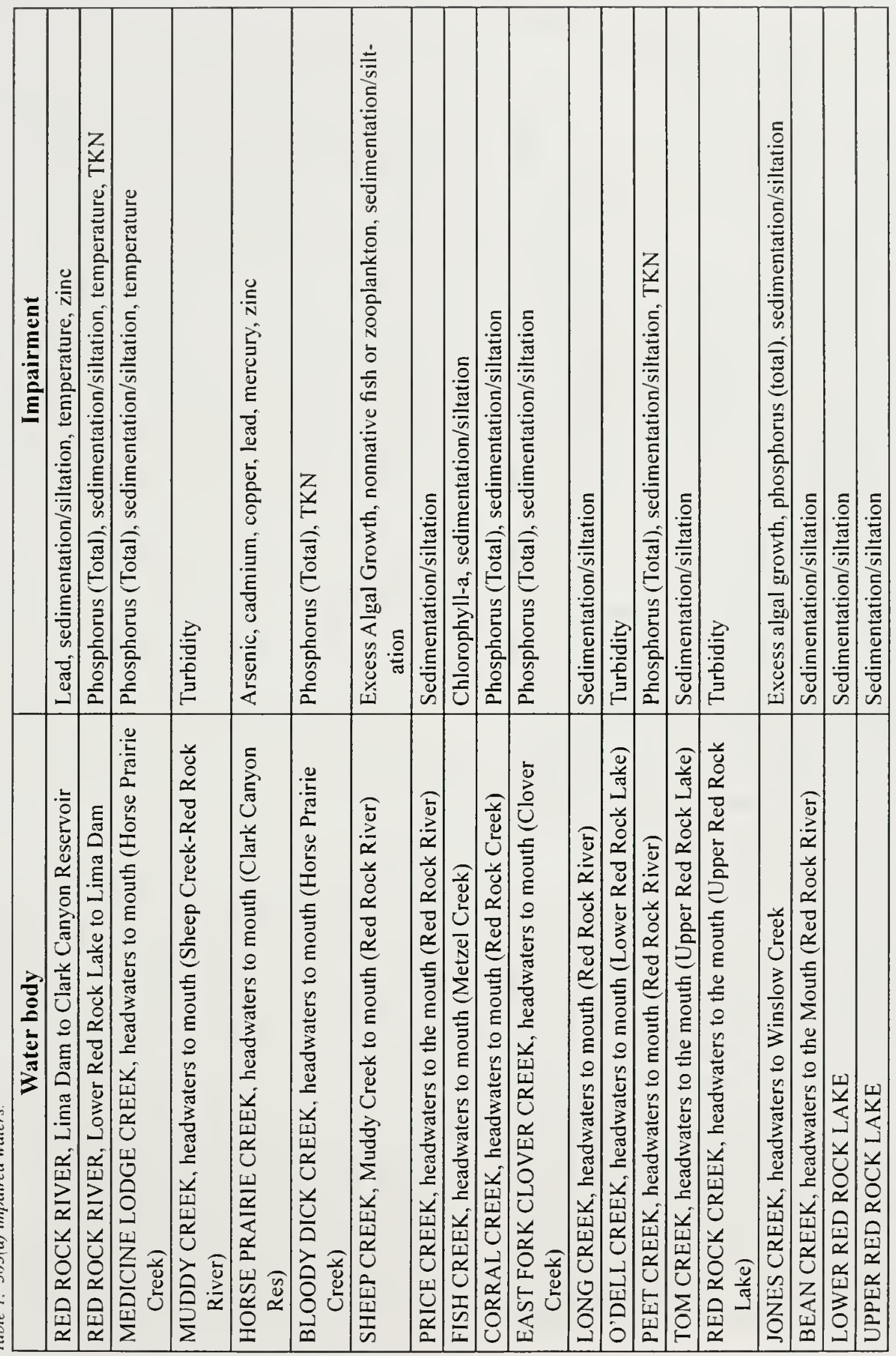


as wetlands are extensive along the upper reaches of Red Rock River and its tributaries.

\section{Natural Communities}

\section{Ecological Systems}

Management of biological diversity rests on our ability to understand how the individual components of that diversity -species, natural communities, ecosystems, and landscapes - are distributed across the landscape, and how they intersect each other. In particular, successful conservation or restoration of individual species depends on the integrity of the biological communities in which they live. Consequently, land managers need to be able to link species to midscale ecological units that can be easily identified, evaluated, and managed. In response to this need, Natural Heritage Programs across the country have put forward the concept of ecological systems (Comer et al. 2003), which represent "recurring groups of biological communities that are found in similar physical environments and are influenced by similar dynamic ecological processes." Ecological systems offer a classification unit that is easily mappable and identifiable in the field and can be crosswalked to other classification systems in use by land management agencies. These ecological communities are the mapping units of the new regional Gap Analysis Program maps (ReGAP), produced under the auspices of the United States Geological Survey.

The ReGAP maps are based on classification of 30-m satellite images, using a massive field data set, and incorporating the input of ecologists and land managers with intimate knowledge of specific landscapes. In Montana, where ReGAP maps have just become available, the Montana Natural Heritage Program has committed itself to further correction and refinement of the classification. Therefore, we consider the current ReGAP layer to be a working draft. However, while the distribution and extent of less common systems need to be verified, the broad characterization of landscapes is reasonably accurate, and we were comfortable relying on it to interpret the ecological systems in the assessment area. Table 2 has a complete list of ecological systems greater than
I,000 acres in size found in the study area; the most prevalent ones are described below.

The most extensive ecological system in the area is Intermountain Basins Montane Sagebrush Steppe, which thrives on cool and semi-arid slopes and ridgetops away from the valley floors (Figure 5). In general, this system is most common in areas of mild topography, fine soils, and more mesic sites where there is subsurface moisture, aboveaverage precipitation, or snow accumulation. It is composed primarily of mountain big sagebrush, silver sagebrush (Artemisia cana ssp. viscidula), and related taxa such as basin big sagebrush and threetip sagebrush. Antelope bitterbrush may codominate or even dominate some stands. Little sagebrush (Artemisia arbuscula ssp. arbuscula) dominated shrublands commonly occur within this system on rocky or windblown sites. In more mesic mountain big sagebrush communities, canopy cover is generally $20-30 \%$, with grassestypically dominated by basin wildrye (Leymus cinereus) and Idaho fescue - making up 60-70\% of the canopy. Forb diversity tends to be low to moderate. On south-facing slopes, mountain big sagebrush cover ranges from $10-40 \%$, with grass canopy in the $40-70 \%$ range. Grass communities are generally dominated by bluebunch wheatgrass (Pseudoroegneria spicata), needle-and-thread and Sandberg bluegrass (Poa secunda).

The next most common ecological system is Middle Rocky Mountain Montane Douglas-fir Forest and Woodland. This Douglas-fir dominated system thrives in a dry to sub-mesic continental climate, typically occurring at the lower treeline immediately above valley grasslands, or sagebrush steppe and shrublands. It includes extensive Douglas-fir forests, occasionally with limber pine on calcareous substrates, and lodgepole pine at higher elevations. Engelmann spruce occurs in some stands within the upper montane zone. Understory shrubs include mallow ninebark (Physocarpus malvaceus), common juniper (Juniperus communis), white spirea (Spiraea betulifolia), snowberry species (Symphoricarpos spp.), buffaloberry (Shepherdia canadensis), and creeping barberry (Mahonia repens). Bilberry (Vaccinium caespitosum) and huckleberry 
Table 2. Major ecological sistems in the assessment area.

\begin{tabular}{|l|l|}
\hline ECOLOGICAL SYSTEM & ACRES \\
\hline & (approx) \\
\hline Inter-Mountain Basins Montane Sagebrush Steppe & 870159 \\
\hline Middle Rocky Mountain Montane Douglas-fir Forest and Woodland & 88314 \\
\hline Rocky Mountain Lodgepole Pine Forest & 59323 \\
\hline Rocky Mountain Subalpine Mesic Spruce-Fir Forest and Woodland & 58668 \\
\hline Rocky Mountain Alpine-Montane Wet Meadow & 55059 \\
\hline Rocky Mountain Subalpine-Montane Mesic Meadow & 50279 \\
\hline Pasture/Hay & 38259 \\
\hline Inter-Mountain Basins Mountain Mahogany Woodland and Shrubland & 34448 \\
\hline Rocky Mountain Subalpine Dry-Mesic Spruce-Fir Forest and Woodland & 32551 \\
\hline Northern Rocky Mountain Lower Montane, Foothill, and Valley Grassland & 28500 \\
\hline Rocky Mountain Subalpine-Montane Riparian Shrubland & 23941 \\
\hline Inter-Mountain Basins Big Sagebrush Steppe & 20916 \\
\hline Rocky Mountain Alpine Turf & 19527 \\
\hline Open Water & 13757 \\
\hline Rocky Mountain Aspen Forest and Woodland & 11396 \\
\hline North American Arid West Emergent Marsh & 11363 \\
\hline Northern Rocky Mountain Subalpine-Upper Montane Grassland & 9748 \\
\hline Cultivated Crops & 9207 \\
\hline Developed, Open Space & 8397 \\
\hline Rocky Mountain Alpine Fell-Field & 6782 \\
\hline Rocky Mountain Subalpine-Montane Riparian Woodland & 5334 \\
\hline Inter-Mountain Basins Active and Stabilized Dune & 3121 \\
\hline Developed, Low Intensity & 2937 \\
\hline Rocky Mountain Alpine Bedrock and Scree & 2853 \\
\hline Harvested forest-grass regeneration & 2688 \\
\hline Introduced Upland Vegetation - Annual and Biennial Forbland & 2144 \\
\hline Wyoming Basins Low Sagebrush Shrubland & 2106 \\
\hline Developed, Medium Intensity & 1239 \\
\hline Rocky Mountain Alpine Dwarf-Shrubland & 1057 \\
\hline
\end{tabular}

(Vaccinium membranaceum) are found on colder, mesic sites. Common grasses include pinegrass, Ross' sedge (Carex rossii), and Geyer's sedge (Carex geyerii). Bluebunch wheatgrass is common on some sites adjacent to upper elevation montane grasslands. Common forbs include yarrow (Achillea millefolium), broadleaf arnica (Arnica latifolia), pussytoes (Antennaria spp.), strawberry (Fragaria virginiana), western rattlesnake plaintain
(Goodyera oblongifolia), twinflower (Linnaea borealis), and beargrass (Xerophyllum tenax). Penstemon (Penstemon spp.) and upland paintbrush species (Castilleja spp.) are found on drier, open sites. Other upland forest ecological systems common to the assessment area include Rocky Mountain Lodgepole Pine Forests and Rocky Mountain Mesic and Dry-Mesic Spruce-Fir Forest and Woodland. 


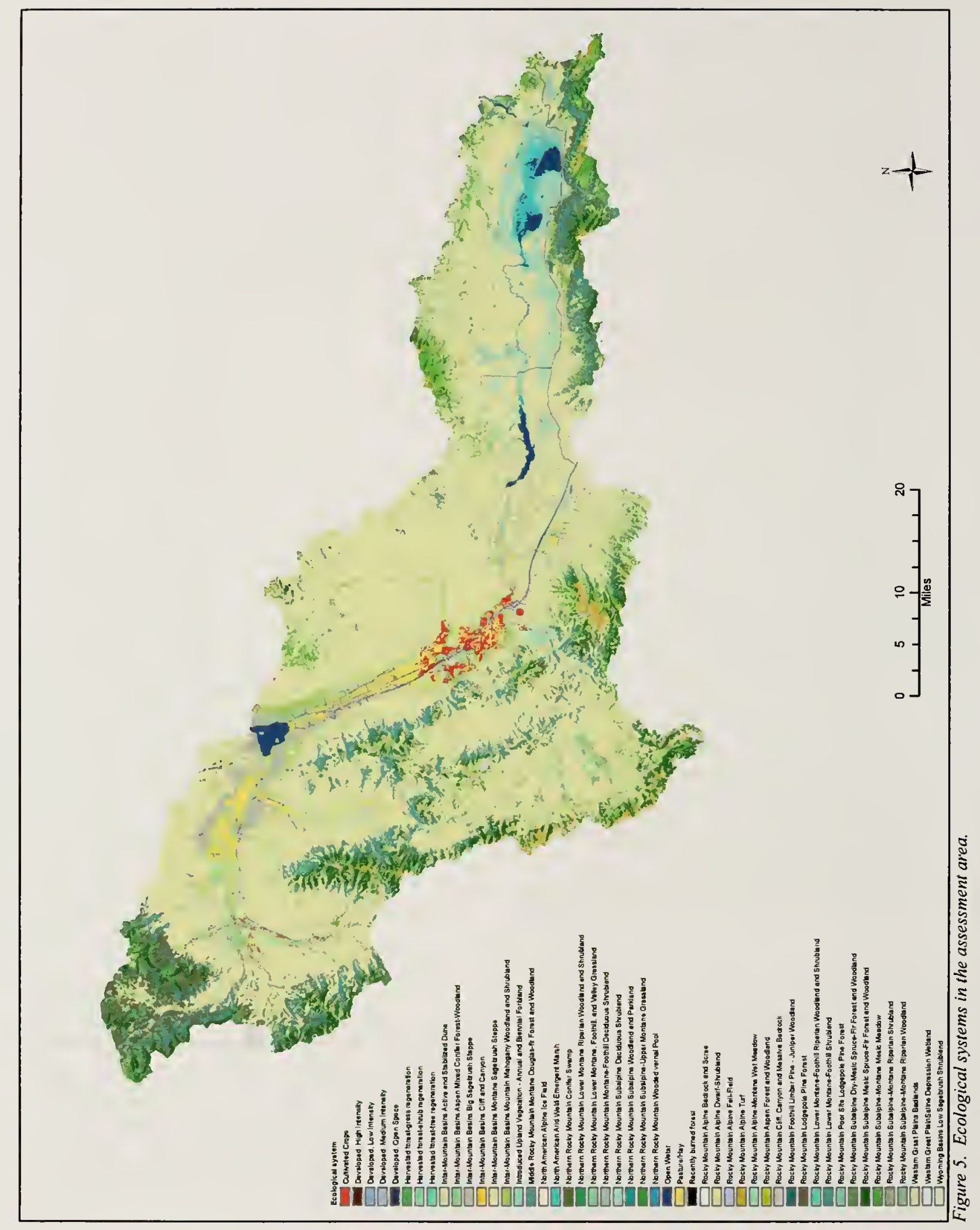


The Rocky Mountain Aspen Forests and Woodlands system occurs in patches throughout the assessment area, usually as small to large patches within wetlands, sagebrush steppe, and Douglas-fir forests. Jean et al. (2002) found the most extensive quaking aspen stands on lower slopes of the northern flank of the Centennial range, particularly on old mass wasting features (earthflows and landslides). In most of the Intermountain west, the distribution of aspen is limited mostly by the soil moisture it needs to meet its heavy evapotranspiration needs (Mueggler 1988); these lower slope locations tend to have more subsurface moisture, allowing the aspen to prosper. Within the assessment area, aspen stands are generally rich in forbs. Tall forbs include Engelmann's aster (Eucephalus engelmamii), western larkspur (Delphinium occidentale), showy stickseed (Hackelia floribunda), cowparsnip (Heracleum maximum), western sweet-cicely (Osmorhiza occidentalis), Fendler's meadowrue (Thalictrum fendleri), or western meadowrue (Thalictrum occidentale), tall ragwort (Senecio serra), and western valerian (Valeriana occidentalis) in the Centennial region. The more common forbs, easily overlooked amongst the luxuriant graminoids, include silvery lupine (Lupinus argenteus), common yarrow (Achillea millefolium), sticky geranium (Geranium viscosissimum), sweet-cicely (Osmorhiza berterois), and woodland strawberry (Fragaria vesca).

Grasslands are also extensive through the assessment area, with the most common upland ecological systems being Rocky Mountain Subalpine-Montane Mesic Meadow, and Northern Rocky Mountain Lower Montane, Foothill, and Valley Grassland.

-Rocky Mountain Subalpine-Montane Mesic Meadows occupy a slightly drier environment and fall into two broad categories: grass-dominated or forb-dominated. Grass-dominated meadows are typically characterized by tufted hairgrass, showy oniongrass (Melica spectabilis), mountain brome (Bromus carinatus), blue wildrye (Elymus glaucus), fowl bluegrass (Poa palustris), and sedges. Forb-dominated meadows are restricted to sites from lower montane to subalpine elevations where finely textured soils, snow deposition, or windswept dry conditions limit tree establishment. Many occurrences are small patch in spatial character and are often found in mosaics with woodlands, more dense shrublands, or just below alpinc communities. Important forbs include common camas (Camassia quamash), aspen daisy (Erigeron speciosus), aster (Eucephalus and Symphyotrichum species), fireweed (Chamerion angustifolium), snall flowered penstemon (Penstemon procerus), harebells (Campamula rotundifolia), Canadian goldenrod (Solidago canadensis), mountain deathcamas (Zigademus elegans), and western meadowrue (Thalictrum occidentale).

- Northern Rocky Mountain Lower Montane, Foothill, and Valley Grasslands occur across the study area. They are found at elevations from 1,000 to 5,000 feet, ranging from small meadows to large open parks surrounded by conifers in the lower montane zone, to extensive foothill and valley grasslands below the lower treeline. Many of these valleys may have been primarily sage-steppe with patches of grassland in the past, but because of land-use history post-settlement (herbicide, grazing, fire suppression, pasturing, etc.), they have been converted to grassland-dominated areas. Soils are relatively deep, fine-textured, often with coarse fragments, and non-saline, and may have a microphytic crust. This system is typified by cool-season perennial bunch grasses and forbs $(>25 \%$ cover $)$, with a sparse $(<10 \%$ cover) shrub cover. Rough fescue (Festuca campestris) and Idaho fescue are usually dominants, and bluebunch wheatgrass occurs as a co-dominant. In the assessment area, these grasslands range from the needle-and-thread / blue grama (Bouteloua gracilis) communities found in valley floors and alluvial fans to bluebunch wheatgrass / Sandberg bluegrass communities on warm aspect, moderate to steep slopes to Idaho fescue / bluebunch wheatgrass grasslands on moderate to steep, predominantly southerly-facing slopes at 6,000-7,500 feet.

Wetlands and riparian areas occur throughout the assessment area, with especially high concentrations in the Centennial Valley. There, the 
most abundant wetland types are Rocky Mountain Alpine-Montane Wet Meadows, Rocky Mountain Subalpine-Montane Fens, and Western North

American Freshwater Marshes.

-Rocky Mountain Alpine-Montane Wet Meadows are moderate-to-high-elevation systems found throughout the Rocky Mountains and Intermountain regions, dominated by herbaceous species found on wetter sites with very low-velocity surface and subsurface flows. Occurrences range in elevation from montane to alpine $(1,000-3,600 \mathrm{~m})$. This system typically occurs in cold, moist basins, seeps, and alluvial terraces of headwater streams or as a narrow strip adjacent to alpine lakes (Hansen et al. 1995). They are typically found on flat areas or gentle slopes, but they may also occur on sub-irrigated sites with slopes up to $10 \%$. In alpine regions, sites typically are small depressions located below late-melting snow patches or on snowbeds. The growing season may only last for one to two months. Soils of this system may be mineral or organic. In either case, soils show typical hydric soil characteristics, including high organic content and/or low chroma and redoximorphic features. This system often occurs as a mosaic of several plant associations, often dominated by graminoids such as tufted hairgrass and a diversity of sedges. Forbs such as groundsels (Senecio spp.) often form high cover in these meadows. Wet meadows are tightly associated with snowmelt and high water tables and are usually not subjected to high disturbance events such as flooding. Salinity and alkalinity are generally low due to the frequent flushing of moisture through the meadow. Depending on the slope, topography, hydrology, soils, and substrate, intermittent, ephemeral, or permanent pools may be present. Standing water may be present during some or all of the growing season, with water tables typically remaining at or near the soil surface. However, fluctuations of the water table throughout the growing season are not uncommon. On drier sites supporting the less mesic types, the late-season water table may be one meter or more below the surface. Soils typically possess a high proportion of organic matter, but this may vary considerably depending on the frequency and magnitude of alluvial deposition. Organic composition of the soil may include a thin layer near the soil surface. Soils may exhibit gleying and/or mottling throughout the profile.

-Rocky Mountain Subalpine-Montane Fens occur infrequently throughout the Rocky Mountains from Colorado north into Canada. They are confined to specific environments defined by groundwater discharge, soil chemistry, and peat accumulation. This system includes poor fens, rich fens, and extremely rich fens. Fens form at low points in the landscape or near slopes where groundwater intercepts the soil surface. Groundwater inflows maintain a fairly constant water level year-round, with water at or near the surface most of the time. Constant high water levels lead to accumulation of organic material. In addition to peat accumulation and perennially saturated soils, the extremely rich and iron fens have distinct soil and water chemistry, with high levels of one or more minerals such as calcium, magnesium, or iron. Fens are among the most floristically diverse of all wetland types, supporting a large number of rare and uncommon bryophytes and vascular plant species, as well as providing habitat for uncommon mammals, mollusks, and insects. Fens also help maintain stream water quality through denitrification and phosphorus absorption. Fens usually occur as a mosaic of several plant associations dominated by sedges (Carex spp.), spikerushes (Eleocharis spp.), and rushes (Juncus spp.). Bryophyte diversity is generally high and includes sphagnum (Sphagnum spp.). In rich and extremely rich fens, forb diversity is equally high. In southern Montana, subalpine and alpine fens potentially occur at higher elevations (Heidel and Rodemaker 2008). These communities typically occur in seeps and wet sub-irrigated meadows in narrow to broad valley bottoms. Soils within this system are organic histosols with $40 \mathrm{~cm}$ or more of organic material if overlying a mineral soil. Organic histosols may be any depth, however, if overlying bedrock, cobbles or gravels. Histosols range in texture from clayey-skeletal to loamy-skeletal and fine-loams.

-Western North American Freshwater Marshes 
occur throughout western North America, typically found in depressions surrounded by an upland matrix of forest, shrub steppe, steppe or mixed prairie vegetation. Within Montana. this system is most common from 671 to $2.256 \mathrm{~m}$ (2,200 to 7,400 fect). Natural marshes occur in and adjacent to ponds and prairie potholes, as fringes around lakes or oxbows, and along slow-flowing streams and rivers as riparian marshes. Wetland marshes are classified as either seasonal, semipermanent, or permanent based on the dominant vegetation found in the deepest portion of the wetland. The type of vegetation that occurs in these marsh systems is representative of their hydroperiod, where some basins dry to bare soil after seasonal flooding while others will have a variety of wetland types in a zoned pattern dependent on seasonal water table depths and salt concentrations. A central shallow marsh zone dominated by graminoids and sedges characterizes seasonal wetlands. Semipermanent and permanent wetlands are continually inundated with water up to $2 \mathrm{~m}$ deep and have a deeper central marsh zone typically dominated by cattails (Typha species) and bulrushes (Schoenoplectus species). In semipermanent systems, the drawdown zone is typically dominated by Northwest Territories sedge and Nebraska sedge (Carex nebrascensis). Water sedge (Carex aquatilis) and/or awned sedge (Carex atherodes) are frequently co-dominant. Inflated sedge (Carex vesicaria) is sometimes intermixed with Northwest Territories sedge or occurs as a co-dominant. especially in riparian marshes associated with beaver activity. Water chemistry may include some alkaline or semi-alkaline situations, but the alkalinity is highly variable even within the same complex of wetlands. Marshes have distinctive soils that are typically mineral, but they can also accumulate organic material. Soils have characteristics that result from long periods of anaerobic conditions in the soils (e.g., gleyed soils, high organic content, redoximorphic features).

\section{Special Status Plants}

The assessment area supports at least 74 vascular plant Species of Concern. These are listed along with vertebrate and invertebrate species in Appendix A.

\section{Wildlife and Fish}

The extensive sagebrush steppe habitat found throughout the assessment area supports several sagebrush obligates, including pygmy rabbit (Brachylagus idahoensis), Sage Thrasher (Oreoscoptes montamus). Brewer`s Sparrow (Spizella breweri), and Greater Sage-Grouse (Centrocercus urophasianus). Greater SageGrouse are found throughout the assessment area, with multiple leks. The abundant small mammal population in sagebrush steppe and grasslands also support concentrated populations of raptors, notably Ferruginous Hawk (Buteo regalis). Prairie Falcon (Falco mexicanus), Swainson's Hawk (Buteo swainsoni). and Golden Eagle (Aquila chrysaetos). Similarly, broadly distributed forests support forest-dependent species like as Hairy Woodpecker (Picoides villosus). Dusky Grouse (Dendragapus obscurus), Ruffed Grouse (Bonasa umbellus). Northern Goshawk (Accipiter gentilis), Red-naped Sapsucker (Splyrapicus nuchalis). and snowshoe hare (Lepus americanus). The Centennial Sandhills, a unique habitat in the Centennial Valley region, support an exceptionally diverse array of invertebrates and vertebrates. A 1999 survey found 18 mammal species, 29 bird species, 3 amphibian and reptile species, 4 tiger beetle species, and 14 butterfly and skipper species (Hendricks and Roedel 2001). Similarly. the extensive wetlands in the Centennial Valley support breeding populations of numerous bird and amphibian Species of Concern. including Trumpeter Swan (Cygmus buccinator), Blackcrowned Night-Heron (Nycticorar nycticorax), White-faced Ibis (Plegadis chihi), Franklin's Gull (Larus pipixcan). Forster's Tern (Sterna forsterii), and boreal toad (Bufo boreas). In addition to the Species of Concern, these wetlands also support breeding populations of western chorus frog (Psendacris triseriata), Columbia spotted frog (Rana luteiventris), and tiger salamander (Ambystoma tigrinum). Beaver are present in low numbers along the Red Rock River, Clark Canyon Creek, and Sheep Creek (BLM 2007). Terrestrial gartersnakes (Thamnophis elegans), common gartersnakes (Thamnophis sirtalis). and western 
rattlesnakes (Crotalus viridis) are common. Gopher snakes (Pituophis catenifer) and rubber boas (Charina bottae) have not been documented but are likely to occur.

Several streams support coldwater fisheries, primarily cutthroat trout (Oncorhynchus clarkii lewisi) and brook trout (Salvelinus fontinalis). Red Rock Lakes and the upper stretches of Red Rock River contain Arctic grayling (Thymallus arcticus), burbot (Lota lota), white sucker (Catostomus contmersoni), longnose sucker (Catostomus catostomus), and mottled sculpin (Cottus bairdi).

The assessment area also has extensive populations of habitat generalists. Both migratory and resident elk (Cervus elephus) are common throughout the region. Pronghorn (Antelocapra americana) inhabit the sagebrush habitats and agricultural fields throughout the area. Mule deer (Odocoileus hemionus) are resident year round. Moose (Alces alces) are plentiful in willow bottoms, especially in and around the willow flats in the eastern Centennial Valley. Black bear (Ursus americanus) use both forested and riparian areas. Mountain lions (Felis concolor), while not common, are seen occasionally. Bighorn sheep (Ovis canadensis) were introduced in the Tendoy Mountains in the late 1980's and early 1990's, and have moved both southward and northward into suitable habitat. Gray wolves (Canis lupus) and grizzly bears (Ursus horribilis) have both been sighted in the assessment area (BLM 2007), and suitable habitat exists for both wolverine (Gulo gulo) and lynx (Lynx canadensis). 


\section{Methods}

\section{Broad-scale Remote Sensing Analysis}

For this analysis, we use a modified version of a broad-scale landscape assessment approach that was developed in prior watershed studies (Vance and Stagliano 2007, Vance and Stagliano 2008) to provide a landscape perspective on the natural diversity, current conditions, and potential threats to wetland and riparian habitats. We began by separating the assessment area into component landscape units so that effective comparisons could be made between units. Based on topography, land cover, and field observations, we decided to analyze the landscape by individual 5 th code hydrologic units. We calculated a number of metrics to allow overall comparisons and provide managers with a basis for planning.

We conducted a GIS analysis using geographic and statistical data to summarize potential and actual watershed condition, and to compare watershed conditions and threats among the landscape units. The analysis was divided into three parts. The first part assessed "background" or natural conditions in the watershed by evaluating ecological diversity and hydrologic and topographic complexity. The second part addressed current conditions and disturbances, including land use, ownership patterns, and alterations and impacts to riparian areas. The third part focused on the primary threat to watershed integrity in the assessment area: riparian grazing.

In each part, indices were created or used to facilitate comparison between watersheds. This index-based approach follows a method initially developed by the Northeast Region of the National Wetland Inventory Program (Tiner et al. 2000), modified and expanded by the Montana Natural Heritage Program (Vance 2005, Vance et al. 2006 ) to address some of the unique conditions in western ecosystems (e.g., grazing impacts, energy development, etc.). This methodology is explained in greater detail in subsequent sections.
National Wetland lnventory photointerpretations dating from the 1980's have only been digitized or turned into hard-copy maps for the USGS quadrangles in the Centennial Valley. The Montana Natural Heritage Program is currently producing wetland and riparian maps for Southwestern Montana. but mapping of this subbasin is incomplete, so no subbasin-wide calculation can be made.

The geographic data used in the assessment and in calculating the sub-indices were derived as follows:

\section{Natural Complexity Index}

a) Hydrologic Complexity Index

- Using the high-resolution National Hydrography Dataset, identify springs. intermittent and perennial streams, and intermittent and perennial lakes, and sum the number and length/area, as appropriate, for each category.

\section{b) Topographic Complexity Index}

- Create a topography polygon layer by reclassifying 10-meter USGS Digital Elevation Maps into 25 elevation classes, and sum acreage in each elevation class.

\section{c) Ecological Diversity Index}

- From ReGAP maps, calculate the diversity of ecological systems in each 5th code HUC.

\section{Composite Wetland Condition Index}

a) Landscape Integrity Index

- Using an inverse weighted distance model that integrates land cover, road density, hydrological modification, and extractive resources such as mining, calculate an integrity score for each pixel in the subbasin, and average the score for each 5 th code HUC.

\section{b) Stream Corridor Integrity Index}

- Buffer stream segments in the 1:100,000 USGS National Hydrography Dataset streams layer; 
- Overlay the buffered stream segments on the 2001 National Land Cover Dataset;

- Sum the acreage of land cover categories within the buffered areas.

\section{Riparian Grazing Threat Index}

- Create a layer of private grazing lands from cadastral records (parcels listed as having grazing as their major land use);

- Create a layer of public grazing lands from cadastral records (parcels listed as having BLM, Forest Service, USFWS, Montana Fish, Wildlife and Parks or the Montana Department of Natural Resources as the owner);

- Overlay the public and private grazing lands layer on the buffered stream layer.

\section{Field Data Collection and Assessment}

During the summer of 2008, MTNHP ecologists carried out Proper Functioning Condition (PFC) assessments at 103 sites in the Centennial
Valley (Figure 6), using the methods described in Pritchard et al. (1999). At 94 of those sites, MTNHP ecologists also conducted ecological integrity assessments, using protocols developed by the MTNHP (See Appendix B). During all phases of data collection, wetlands were classified with the National Wetland Inventory (NWI) system (Cowardin et al. 1979). We also assigned wetlands to broad ecological systems, using the classifications and descriptions developed by NatureServe and the MTNHP. For both wetland and upland plants, our principle floristic references were Dorn (1984) and the Flora of the Great Plains (1977, 1986). All plant nomenclature follows Kartesz (1999).

Riparian habitat assessments, water quality parameter measurements, and macroinvertebrate surveys were performed at thirteen sites. Biological community integrity was calculated at all sites using the Montana Macroinvertebrate Multimetric Index (MT MMI). 


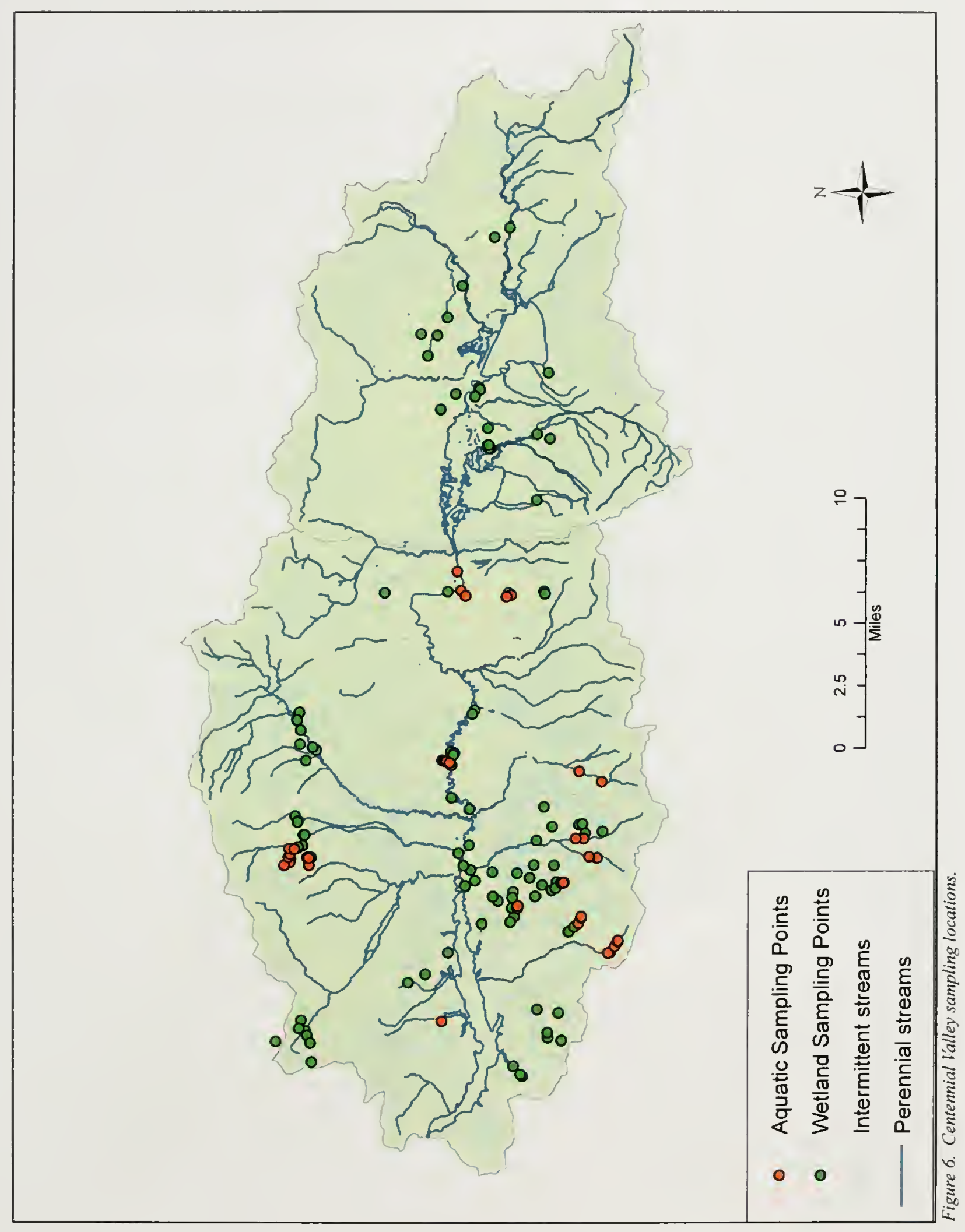




\section{Results AND Discussion}

\section{Overview}

\section{Current Conditions}

The assessment area lies in a sparsely-populated part of Montana, where most of the land is in public ownership. Across the Red Rock River subbasin area, the BLM Dillon Field Office owns or manages approximately 411,977 acres (206,497 hectares). The BLM State Office owns an additional 21,328 acres $(8,631$ hectares $)$ in the Centennial Mountains Wilderness Study Area. Altogether, the BLM has responsibility for 433,305 acres (175,352 hectares) in the Red Rock River subbasin, almost $29 \%$ of the area. The Forest Service is the next largest public land owner, managing 391,924 acres (158,606 hectares). In the two watersheds of the Centennial Valley (Lima Reservoir and Red Rock Lakes), the BLM owns or manages approximately 106,213 acres $(42,983$ hectares). The U.S. Fish and Wildlife Service manages almost 100,000 acres $(40,469$ hectares) in these two watersheds ${ }^{2}$, and both the Nature Conservancy and Montana Land Reliance have substantial easements on private lands.

Across the subbasin as a whole, $45 \%$ of the land cover is grassland, $31 \%$ is shrubland, $17 \%$ is forest, and $4 \%$ is agriculture. Wetlands make up less than $2 \%$ of the landcover. In the Centennial Valley, $35 \%$ of the land cover is grassland, $37 \%$ is shrubland, $16 \%$ is forest, $8 \%$ is wetland, and $2.5 \%$ is open water. Throughout the subbasin, both public and private grasslands and shrublands are used primarily for cattle grazing. Most of the agricultural use is along the valley bottoms adjacent to Red Rock River and Horse Prairie Creek.

The assessment area encompasses 1,481,484 acres (599,535 hectares), of which 44,225 acres $(17,897$ hectares) are lakes, ponds, or manmade reservoirs. There are 1,573 miles (2,531 kilometers) of perennial streams and rivers, and 4,315 miles (6,944 kilometers) of intermittent streams. Some of these intermittent streams are headwater streams that flow only during snowmelt; others, especially in more arid portions of the subbasin, are in fact ephemeral, flowing only in response to heavy rain events.

\section{Factors and Magnitude of Change}

Since Euro-American settlement, three human activities have impacted watershed health and integrity in this part of Montana: extraction, diversion, and impoundment of water; conversion of riparian floodplains to agriculture; and livestock grazing. Associated impacts such as roadbuilding, and secondary impacts, such as lowintensity residential development, have also altered natural conditions.

\section{Extraction, diversion, and impoundment of water}

Flows in Red Rock River are moderated by major upstream and downstream impoundments, and influxes from many tributary streams are reduced by diversion and impoundment. Nonetheless, flows prior to irrigation season are sufficient to maintain a more-or-less natural hydrologic regime, with floods and peak flows occurring at regular intervals. The hydrographs for Red Rock River above Red Rock Lake and below Lima Dam have similar peak discharge intervals, although base flows from the dam are lower during summer months than they would be in the absence of the reservoir (Figures 9a and 9b).

Across the assessment area, small dams, diversions, and impoundments on headwater and mainstem streams tend to minimize temporal variability in stream flows. By eliminating flood peaks, these dams, diversions, and impoundments lead to narrowing and firming of channel beds over time, and to the loss of bare substrate on streambanks that is necessary for successful regeneration of woody vegetation. Some of the streams in the assessment area have also downcut significantly over time, and in many areas, only remnant (and decadent) cottonwoods remain. While our onsite investigations were restricted to streams in and around the Centennial Valley, we noted that the

\footnotetext{
${ }^{2}$ The USFWS lands include the 45,000 acre Red Rocks National Wildlife Refuge in the Centennial Valley.
} 


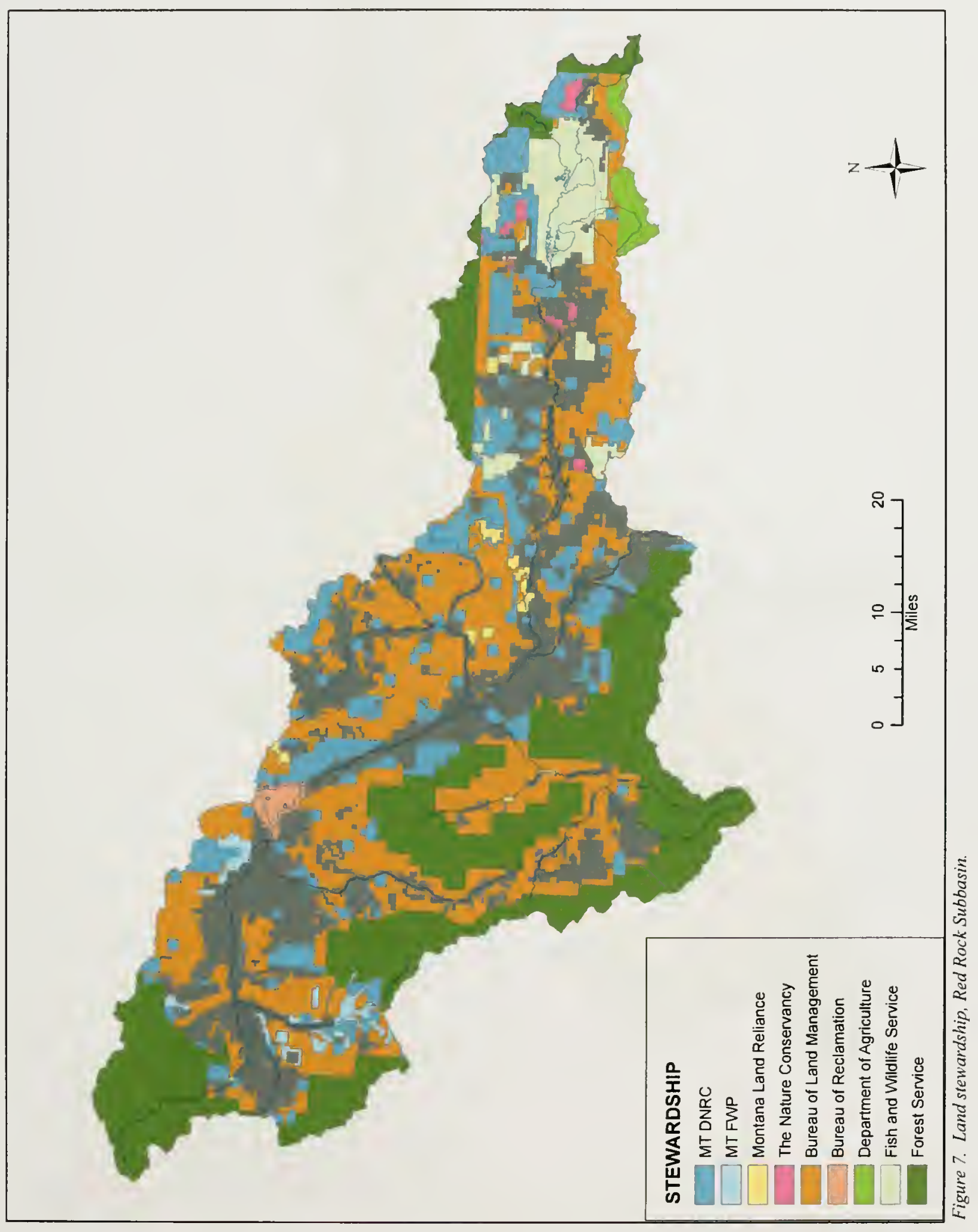




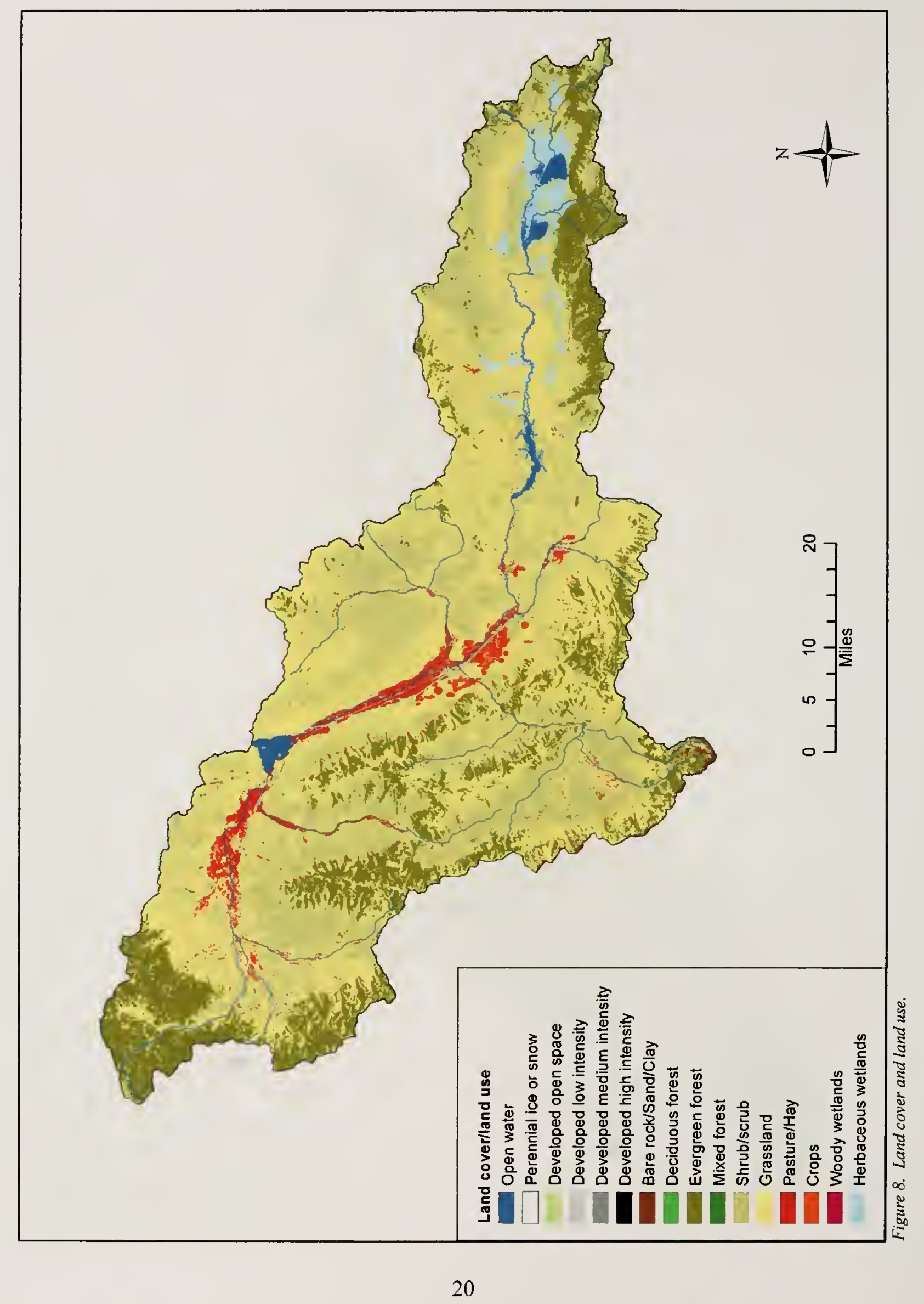



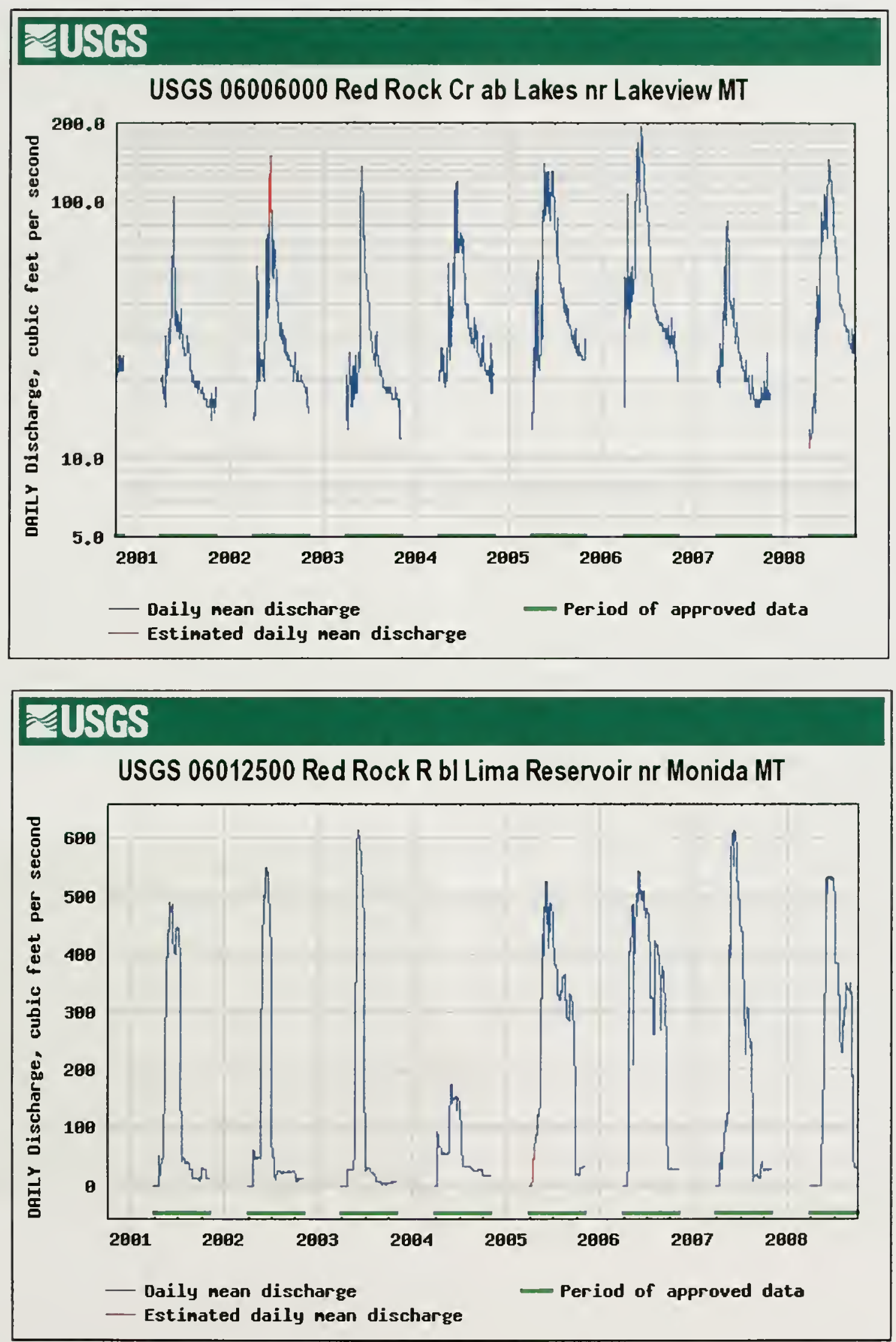

Figure $9 a$ and $9 b$. Hydrographs for Red Rock River ganging stations, 2000-2008. 
BLM watershed assessment of the downstream portions of the subbasin found many riparian areas to be functioning at risk (BLM 2007).

\section{Conversion of riparian floodplains to agriculture}

Floodplain conversion can affect watershed health and integrity in a number of ways. First, it is generally accompanied by water withdrawal for agricultural use; second, it eliminates or impedes regrowth of native vegetation while facilitating invasion by weedy species; and third, erosion from tillage and farm roads contributes to increased sedimentation of streams and rivers (Power et al. 1995). In the assessment area, agricultural conversion of floodplains along the Red Rock River and Horse Prairie Creek is extensive. In the subbasin as a whole, $4 I 6,446$ acres are private agricultural uses, with 370,222 acres reported as having grazing as their primary use, 30,787 acres reported as irrigated agriculture, and 7,454 as wild hay. Over 20,000 acres of irrigated agriculture and 4,600 acres of wild hay land lie within a mile of Red Rock River, Horse Prairie Creek, Red Rock Lakes, Lima Reservoir, or Canyon Creek Reservoir.

Both publicly and privately owned grasslands in the subbasin are used for grazing. While this is not strictly a conversion, both grazing and crop production put heavy demands on water supplied by wells and surface water diversions. Agricultural conversion also puts aquatic resources at risk through increased erosion and sedimentation, while overgrazing can lead to invasion of grasslands by non-native plant species. During our field surveys, we observed widespread Canada thistle (Cirsium arvense) and Kentucky bluegrass (Poa pratensis) in grazed grassland areas.

\section{Livestock grazing}

As noted earlier, livestock grazing is the dominant agricultural use in the assessment area. Cattle are the most common grazing animals, although sheep are still present in small numbers. Although many ecosystems east of the Continental Divide evolved under grazing pressures from hoofed ungulates, the seasonality and intensity of bison and elk grazing differ from current systems. If not managed optimally or effectively, cattle and sheep grazing can cause soil compaction, nutrient enrichment, vegetation trampling and removal, habitat disturbance, and, depending on the season and intensity of use, reproductive failure for native plants and animals. Grazing in riparian areas can cause stream and river bank destabilization, loss of riparian shade, and increased sediment and nutrient loads in the aquatic ecosystem (George et al. 2002). Stock watering tanks can contribute to dewatering of streams and aquifers, and may concentrate livestock movement and congregation in sensitive areas. During hot summers, cattle and sheep prefer to loaf in shady areas, trampling understory vegetation.

In our field surveys, we saw several instances where cattle had free access to riparian and wetlands areas, and some cases where pugging and hummocking had severely impacted both the soil and the vegetation (Figures $10 \mathrm{a}$ and $10 \mathrm{~b}$ ). Springs and seeps were also frequently impacted. While we saw individual instances of fencing and exclusion, most of the aquatic resources were unprotected.

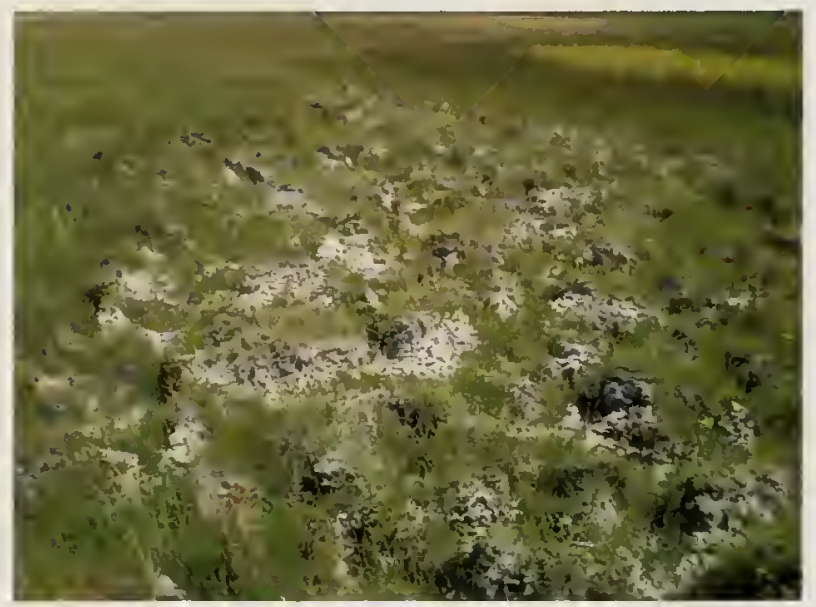

Figure 10a. Pugging in a Centennial V'alley wetland. 


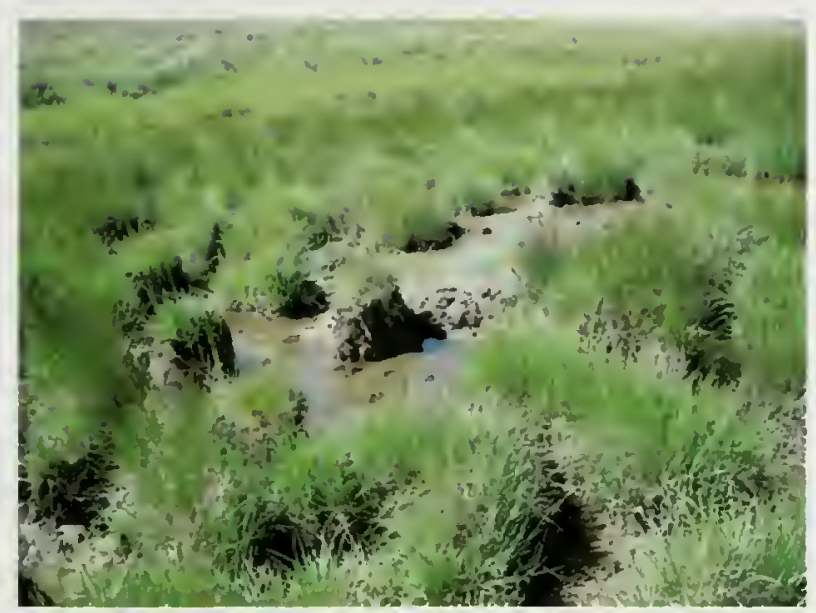

Figure lob. Hummocking in a Centennial Valley wetland.

\section{Broad-Scale Assessment Indices}

In previous watershed assessments (Crowe and Kudray 2003, Vance 2005, Vance et al. 2006), the Montana Natural Heritage Program developed a method for broad-scale assessment of wetlands based on a procedure originally developed by the Northeast Region of the U.S. Fish and Wildlife Service's National Wetland Inventory Program (Tiner et al. 2000). We have continued to refine this method by adding new metrics, dropping redundant or insensitive metrics, and refining scoring for land use categories. We believe that these ongoing refinements provide a better baseline for assessment, and more accurately evaluate the stressors found in western watersheds.

This assessment procedure has three components. First, we generated a Composite Natural Complexity Index, based on underlying vegetation, hydrologic, and elevation factors, to capture the extent and variation of natural conditions within the overall assessment area and the individual watersheds. Each of the sub-indices is scaled from 0.0 to 1.0 , with higher scores reflecting greater complexity. ${ }^{3}$

Next, we used a landscape integrity index and a stream corridor integrity index to produce an overall Composite Watershed Condition Index (CWCl). This index gives a sense of how much pre-settlement habitat remains in the assessment area watersheds, emphasizing riparian systems and adjacent upland habitat, i.e. buffers. The landscape integrity index integrates several disturbance factors including roads, agricultural development, hydrologic alterations, and mines. The stream corridor integrity index synthesizes the extent of human land uses within a riparian corridor. These indices are added together to create the Composite Watershed Condition Index $(\mathrm{CWCI})$ for each 5 th code HUC.

In the final step, we calculated a Riparian Grazing Threat lndex. Grazing has both current and long term impacts, so we have designated it as an ongoing threat. However, it is easily mitigated by the adoption of grazing management practices. By indicating where potential threats occur, appropriate management plans can be identified and implemented. Here, higher scores signal a higher level of threat.

One criticism of indices of biological integrity is that individual characteristics of the system being assessed are blurred by the act of collapsing multiple metrics into a single number (Moyle and Marchetti 1999). To offset this effect, we have chosen to keep the three overall indices separate. This way, characteristics of each watershed can be compared without significantly diminishing the magnitude of specific disturbances or threats.

\section{Composite Natural Complexity Index}

The Composite Natural Complexity Index measures the richness and extent of vegetation, hydrologic features, and topography. It has three subindices, the Natural Community Complexity Index, the Hydrologic Complexity Index, and the Topographic Complexity lndex, explained below.

\section{Natural Community Complexity Index (INC) The Natural Community Complexity lndex is a simple measure of the number of ecological systems in individual watersheds relative to the total number of ecological systems across the study}

\footnotetext{
${ }^{3}$ In earlier assessments. we were also able lo evaluate welland diversity as part of this index; in this assessment area wetland mapping was not complete by the lime of this report. so this part of the assessment could not be performed. However, our field survey's indicated that there is considerable wetland diversity in these watersheds, and large numbers of natural wetlands.
} 
area. Ecological systems are defined as groups of plant community types that tend to co-occur within areas that have similar ecological processes, substrates, and/or environmental gradients (Comer et al. 2003). Spatially, ecological systems occur at the scale of less than an acre to tens of thousands of acres; temporally, they persist for 50 to 150 years. This temporal scale allows typical successional dynamics to be integrated into the concept of each ecological system. Because individual ecological systems themselves may contain multiple community types, system richness is a good indicator of complexity ${ }^{4}$. There are 40 different natural ecological systems in the assessment area as a whole. Natural community complexity was calculated by dividing the number of ecological systems in each 5 th code $\mathrm{HUC}$ by the number of systems in the assessment area. The results were relativized by dividing all scores by the highest score.

Table 3. Natural Community Complexity Index

\begin{tabular}{|l|l|}
\hline Red Rock Lakes & 1.00 \\
\hline Lima Reservoir & 0.95 \\
\hline Lower Horse Prairie Creek & 0.95 \\
\hline Nicholia Creek & 0.92 \\
\hline Upper Horse Prairie Creek & 0.89 \\
\hline Bloody Dick Creek & 0.87 \\
\hline Medicine Creek & 0.87 \\
\hline Junction Creek & 0.84 \\
\hline Little Sheep Creek & 0.84 \\
\hline Red Rock River & 0.79 \\
\hline Big Sheep Creek & 0.76 \\
\hline Sage Creek & 0.66 \\
\hline Cabin Creek & 0.61 \\
\hline Muddy Creek & 0.58 \\
\hline
\end{tabular}

The Red Rock Lakes, Lima Reservoir, and Lower Horse Prairie Creek watersheds had the highest Natural Community Complexity scores, indicating that they have the greatest ecological diversity. These three watersheds all cross several ecological subsections and have a considerable range of elevations. The Muddy Creek watershed scored lowest. It is primarily a lower-elevation watershed characterized by shrub and steppe ecological systems with limited forest cover.

\section{Hydrologic Complexity Index (IHC)}

The Hydrologic Complexity Index describes the number and density of hydrologic features in a watershed (springs, seeps, perennial lakes and streams, and intermittent lakes and streams). By characterizing the number and extent of these features, this subindex allows managers to prioritize watersheds for management efforts or further assessment. Although many of the lakes and ponds are manmade, we have included them in the analysis because they provide significant habitat when managed for those values.

We calculated this index by summing 1) the number of springs and seeps 2) the number of lakes, ponds, and reservoirs per 100 square miles of watershed; 3 ) the number of wetlands per 100 square miles of watershed 4) the density of perennial streams (in miles of stream per square miles of watershed); 5) and the density of intermittent streams (in miles of stream per square miles of watershed). Each of the 14 watersheds received a rank of 1-14 in each category (springs, lake density, wetland density, perennial stream density, and intermittent stream density). Low scores in a category meant that the watershed had the lowest density of the feature in question. Scores were summed across the categories, and averaged for each watershed. This was then relativized by taking the highest score, and dividing all other scores by that score.

Based on this analysis, the Red Rock Lakes watershed has the most Hydrologic Complexity while the Little Sheep Creek watershed has the least. The Red Rock Lakes watershed is a headwaters area with numerous lakes, ponds, springs, seeps, wetlands, and perennial streams. Little Sheep Creek, which is also considerably smaller is size, is located in the Dry GneissicSchistose Volcanic Hills and Barren Mountains

\footnotetext{
${ }^{4}$ It is possible thal ecological systems richness is a function of patchiness resulting from human land uses. However, in 1 he assessment area. our field observations led us to conclude that this was nol the case, bul rather thal ecological system richness did in fact reflect more natural conditions.
} 
ecological subsections, both characteristically arid, with few perennial streams, wetlands, and springs. Table 4 shows the individual scores on this metric.

Table 4. Itvdrologic Complexity Index.
\begin{tabular}{|l|l|}
\hline Red Rock Lakes & 1 \\
\hline Lima Reservoir & 0.89 \\
\hline Bloody Dick Creek & 0.89 \\
\hline Nicholia Creek & 0.84 \\
\hline Junction Creek & 0.82 \\
\hline Big Sheep Creek & 0.78 \\
\hline Medicine Lodge Creek & 0.73 \\
\hline Lower Horse Prairie Creek & 0.71 \\
\hline Sage Creek & 0.60 \\
\hline Cabin Creek & 0.56 \\
\hline Upper Horse Prairie Creek & 0.47 \\
\hline Red Rock River & 0.47 \\
\hline Muddy Creek & 0.44 \\
\hline Little Sheep Creek & 0.35 \\
\hline
\end{tabular}

Topographic Complexity Index (ITC) Topography influences plant community composition and habitat availability for animal populations. Increased topographic diversity within a watershed increases the availability of niches and microhabitats, which in turn provides habitat for rare species with unique habitat requirements while also ensuring suitable habitat for a broad suite of species.

Elevations in the assessment area range from 1,688 to 3,397 meters $(5,538$ to 11,145 feet $)$ above sea level. Scores on this sub-index were calculated by using a GIS to create 25 equal elevation bands across the assessment area. We summed the number of elevation bands in each watershed, took the $\log$ of that sum, and relativized the scores by dividing each log score by the highest log score. Table 5 shows the scores on this metric. The Little Sheep Creek watershed has the highest Topographic Complexity score, while the Muddy Creek watershed has the lowest.

Composite Natural Complexity Index (CNCI) We combined the three sub-indices into a Composite Natural Complexity Index. This index
Table 5. Topographic Complexity Index.

\begin{tabular}{|l|l|}
\hline Little Sheep Creek & 1.00 \\
\hline Junction Creek & 0.99 \\
\hline Big Sheep Creek & 0.99 \\
\hline Medicine Lodge Creek & 0.97 \\
\hline Nicholia Creek & 0.96 \\
\hline Lower Prairie Horse & 0.96 \\
\hline Cabin Creek & 0.94 \\
\hline Upper Prairie Horse Creek & 0.94 \\
\hline Red Rocks River & 0.94 \\
\hline Sage Creek & 0.91 \\
\hline Red Rock Lakes & 0.90 \\
\hline Lima Reservoir & 0.90 \\
\hline Bloody Dick Creek & 0.90 \\
\hline Muddy Creek & 0.84 \\
\hline
\end{tabular}

has a maximum possible score of 3.00 , which would mean the watershed had a score of 1.00 on each of the three complexity metrics. Table 6 shows the scores on this composite index. As the scores indicate, the Red Rock Lakes 5th code HUC has the highest natural complexity among the assessment area watersheds, while the Muddy Creek 5th code HUC, which had the lowest scores on the Natural Community Complexity and Hydrologic Complexity sub-indices, has the lowest complexity.

Table 6. Composite Natural Complexity Index
\begin{tabular}{|l|c|}
\hline Red Rock Lakes & 2.85 \\
\hline Lima Reservoir & 2.69 \\
\hline Nicholia Creek & 2.67 \\
\hline Bloody Dick Creek & 2.62 \\
\hline Junction Creek & 2.60 \\
\hline Lower Prairie Horse & 2.56 \\
\hline Medicine Lodge Creek & 2.52 \\
\hline Big Sheep Creek & 2.49 \\
\hline Upper Prairie Horse Creek & 2.26 \\
\hline Red Rocks River & 2.16 \\
\hline Little Sheep Creek & 2.15 \\
\hline Sage Creek & 2.14 \\
\hline Cabin Creek & 2.08 \\
\hline Muddy Creek & 1.83 \\
\hline
\end{tabular}


Composite Watershed Condition Index

The Composite Watershed Condition Index is made up of three sub-indices. The first is a Landscape Integrity Index, derived from a model developed by Vance (2009). This is an inverse weighted distance model premised on the idea that ecosystem processes and functions achieve their fullest expression in areas where human activities have the least impact. It was specifically developed as a broad-scale method for assessing wetland health. It presumes that wetland condition will be highest when wetlands are isolated from roads, commercial or industrial development. urban areas, resource extraction sites. or hydrologic modifications. The second, the Stream Corridor Integrity Index, measures the amount of natural land cover within a set buffer on either side of all perennial and intermittent streams. The third index is the Riparian Loss Index. This estimates the amount of riparian vegetation that has been lost since European settlement. To calculate the Composite Watershed Condition Index. scores on the two integrity indices are summed, and the loss index score is subtracted.

\section{Landscape Integrity Index (ILI)}

The model uses four categories of human impacts. The first. land cover and land use. identifies urban areas, croplands, and timber harvest areas as stressors. The second. roads, is broken into three classes: four-wheel drive roads, local roads, and state/federal highways. The third category is hydrologic modification. This consists of dammed stream and river segments, water rights points of use. and Clean Water Act section 404 permits. The fourth category is resource extraction and consists of energy wells (gas, oil, coalbed methane) and current or abandoned mines.

The four categories of impacts are weighted and summed into a single raster layer, with a pixel size of 30 meters by 30 meters, or 900 square meters. To calculate mean values for a given assessment area (in this case, 5th code HUCs) we used the zonal statistics tool in ArcGIS 9.3. Mean scores were converted to a 0 to I scale with the formula I-Log 0 (raw landscape integrity score). The resulting scores were relativized to obtain the final results, shown in Table 7.
Table 7. Landscape Integrity Index.

\begin{tabular}{|l|c|}
\hline Muddy Creek & I.00 \\
\hline Sage Creek & 1.00 \\
\hline Nicholia Creek & 0.99 \\
\hline Cabin Creek & 0.99 \\
\hline Red Rock Lakes & 0.98 \\
\hline Medicine Lodge Creek & 0.98 \\
\hline Lima Reservoir & 0.98 \\
\hline Big Sheep Creek & 0.95 \\
\hline Bloody Dick Creek & 0.94 \\
\hline Junction Creek & 0.93 \\
\hline Upper Horse Prairie Creek & 0.91 \\
\hline Little Sheep Creek & 0.90 \\
\hline Lower Horse Prairie Creek & 0.87 \\
\hline Red Rock River & 0.87 \\
\hline
\end{tabular}

In general, the watersheds in the study area have not been heavily disturbed by human activities; human impacts are relatively concentrated, and at the watershed scale, are offset by large roadless areas with no permanent development. The Muddy Creek and Sage Creek watersheds have the highest scores on the Landscape Integrity Index, while the Red Rock River and Lower Horse Prairie Creek watersheds, where most agricultural land use is concentrated, have the lowest scores.

\section{Stream Corridor Integrity Index (ISCI)}

The Stream Corridor Integrity Index measures the amount of natural land cover within a set buffer on either side of all perennial and intermittent streams. It was calculated by creating a 60 -meter buffer on each side of the stream segments in the $1: 100,000$ National Hydrography Dataset and assessing land cover and land use from the NLCD. Although higher resolution stream data are available and were used in other calculations (e.g., the Hydrologic Complexity Index), these data include many ephemeral streams and drainages where transport of sediment, runoff. and pollution may be minimal. By using lower-resolution data, we hoped to capture perennial and intermittent streams while avoiding ephemeral drainages.

This index offers a way to determine whether areas adjacent to streams are contributing more 
than natural amounts of sediment, runoff, and pollution. Croplands and fallow fields will produce higher sedimentation rates than naturally vegetated areas (Wilkin and Hebel 1982), and activities that create impermeable cover (particularly roads and commercial, industrial, or residential development) will lead to elevated runoff levels, as well as overland transport of chemical pollutants.

The Stream Corridor Integrity Index, as developed by Tiner et al. (2000), is generally a simple ratio of naturally vegetated stream corridor to total stream corridor area, with no allowance made for either grazing impacts or types of non-vegetation cover. Accordingly, we weighted the various land uses in terms of their assumed impacts on riparian systems. We assumed, for example, that grazing pressure would be better characterized as "moderate" than as "light" in riparian grasslands, as cattle are prone to congregate near sites offering shade and water, but that riparian grasslands would be more lush and therefore somewhat more resilient to grazing than more water-stressed uplands. Following Hauer et al. (2002), we therefore gave grasslands in the stream corridor (which we assumed were all grazed) a weight of 0.6 . Again following the weights assigned by Hauer et al. (2002) for riparian corridors, we changed the weight assigned to Hay or Pasture from a 0.6 to a 0.5 to reflect the higher risk of erosion, sedimentation, and nutrient enrichment from agricultural activities near a stream. The weights we used for individual activities in the calculation of the Stream Corridor Index were:

Use

Other

Open Water

Low intensity residential

Commercial, industrial, transportation

Bare rock, sand or clay

Deciduous forest

Evergreen forest

Mixed forest

Shrubland

Grassland or herbaceous

Pasture or hay

\section{Weight}

0.5

1.0

0.0

0.0

1.0

1.0

1.0

1.0

1.0

0.6

0.5
Cultivated crops/fallowed land

0.2

Developed, open space

0.4

Herbaceous wetlands

1.0

Woody wetlands

1.0

We then calculated this index as:

$\mathrm{ISCI}=\mathrm{ALCWt} / \mathrm{ATC}$,

where $\mathrm{ALCWt}=$ the sum of the weighted scores for land cover in acres and ATC $=$ total stream corridor area, in acres.

We report 60 meters as the buffer width on each side of the streams ( 100 meters total) because many of the tributary corridors are in relatively confined valleys, but we found little difference between scores calculated with 60,120 , and 180 meter buffers. $^{5}$ As can be seen from Table 8 , the Red Rock Lakes watershed retains the highest amount of stream corridor integrity, while the Lower Horse Prairie Creek watershed appears to have the greatest amount of disturbance along the corridor.

Table 8. Stream Corridor Integrity Index.

\begin{tabular}{|l|c|}
\hline Red Rock Lakes & 0.96 \\
\hline Lima Reservoir & 0.84 \\
\hline Muddy Creek & 0.81 \\
\hline Bloody Dick Creek & 0.80 \\
\hline Cabin Creek & 0.80 \\
\hline Medicine Lodge Creek & 0.79 \\
\hline Sage Creek & 0.77 \\
\hline Nicholia Creek & 0.76 \\
\hline Upper Horse Prairie Creek & 0.76 \\
\hline Big Sheep Creek & 0.76 \\
\hline Little Sheep Creek & 0.71 \\
\hline Red Rock River & 0.70 \\
\hline Junction Creek & 0.69 \\
\hline Lower Horse Prairie Creek & 0.69 \\
\hline
\end{tabular}

\section{Riparian Loss Index (IRL)}

Land use activities within the stream and river corridor are one measure of the departure from natural conditions; another is direct loss of riparian

\footnotetext{
${ }^{5}$ We used $60 \mathrm{~m}$ ralher than 50 because the NLCD is based on $30 \mathrm{~m}$ grids.
} 
vegetation. This is especially true along the major streams and rivers in the region of the assessment area, where cottonwoods, mixed forests, or willow shrublands should be dominant land cover features. To approximate riparian loss, we used the $200 \mathrm{I}$ National Land Cover Dataset to create a vegetation layer that includes forests and woody wetlands. Willow-dominated shrublands are generally classified as woody wetlands in the NLCD, while cottonwoods are usually assigned to the deciduous forest class. Because there are some evergreen forests along higher elevation streams, we included all forest types (deciduous, evergreen and mixed) in this calculation. We buffered all streams from the I: I00.000 National Hydrography Dataset by 60 meters on each side, and calculated the acres of riparian vegetation.

To be on the conservative side, and recognizing the inaccuracies inherent in land cover data at this resolution, we calculated that under natural conditions, the riparian corridor area would include at least $30 \%$ forest and woody wetland vegetation. Any departure from that was held to be a loss. The index was calculated as:

$I R L=I-(A R V) /(0.50 * A T R)$,

where $\mathrm{ARV}=$ the acreage of riparian vegetation within the buffered corridor, and ATR $=$ the total riparian corridor area, in acres.

Table 9 shows the Riparian Loss scores for each watershed; high scores indicate a greater level of disturbance, while low scores equal a lower level. Negative scores mean that the current riparian corridor is more than $30 \%$ forested. There was a large spread between scores, ranging from a high of 0.45 for the Junction Creek and Lower Horse Prairie Creek watersheds to a low of -0.18 for the Red Rock Lakes watershed. Although many of the watersheds with less than $30 \%$ woody cover in the riparian corridor are in semi-arid areas, in the absence of stream incision and diversion of stream flows, we would expect more willows and other riparian shrubs. Therefore, we suggest that there has been significant loss of woody riparian vegetation since pre-settlement times in several of the assessment area watersheds. However, we also note that ten of the fourteen watersheds still have close to, or more than, an average of $30 \%$ woody cover along their streams and rivers.

Table 9. Riparian Loss Index.

\begin{tabular}{|l|l|}
\hline Red Rock Lakes & -0.18 \\
\hline Muddy Creek & -0.04 \\
\hline Bloody Dick Creek & -0.03 \\
\hline Medicine Lodge Creek & -0.03 \\
\hline Cabin Creek & 0.02 \\
\hline Lima Reservoir & 0.10 \\
\hline Upper Horse Prairie Creek & 0.13 \\
\hline Big Sheep Creek & 0.13 \\
\hline Sage Creek & 0.14 \\
\hline Nicholia Creek & 0.17 \\
\hline Little Sheep Creek & 0.26 \\
\hline Red Rock River & 0.37 \\
\hline Lower Horse Prairie Creek & 0.45 \\
\hline Junction Creek & 0.45 \\
\hline
\end{tabular}

Composite Watershed Condition Index (CWCI) The Composite Watershed Condition Index is calculated by subtracting the Riparian Loss Index from the Landscape Integrity Index and the Stream Corridor Integrity Index.

$C W C I=(I L I+I S C I)-(I R L)$

The highest possible score would be 2.00 , assuming scores of 1.00 (best) on each of the integrity indices and 0.00 (best) on the Riparian Loss Index. Because we had negative scores on the Riparian Loss Index, we had one CWCI score over 2.00 , so all scores were converted to a range of 0.00 to 2.00 by dividing them by 0.5 of the high score. A score of 2.00 represents the sort of conditions associated with remote, undeveloped areas with little history of mining, agriculture, or other human land use other than grazing. For inhabited areas, scores will be much lower and could be a negative number when integrity indices are low and riparian loss is high. We would expect to see scores between I.00 and I.50 in inhabited rural watersheds. 
The Composite Watershed Condition scores are shown in Table 10 and in Figure 11. All the watersheds received positive scores, ranging from highs of 2.00 for the Red Rock Lakes watershed to a low of 1.05 . Half of the watersheds in the assessment area scored higher than 1.50, and two were very close (1.49). In general, this indicates that there are relatively few landscapelevel disturbances affecting watershed health and integrity, and that they tend to be concentrated in a handful of watersheds. The highest-scoring Red Rock Lakes watershed has a high percentage of U.S. Fish and Wildlife Service, Nature Conservancy, and BLM- and Forest Servicemanaged land, and is sparsely populated. By contrast, the lowest scoring watersheds (Lower Horse Prairie Creek, Junction Creek, Red Rock River) have more population, and concentrations of agriculture on riparian floodplains.

Table 10. Composite Watershed Condition Index.

\begin{tabular}{|l|l|}
\hline Red Rock Lakes & 2.00 \\
\hline Muddy Creek & 1.74 \\
\hline Medicine Lodge Creek & 1.70 \\
\hline Bloody Dick Creek & 1.67 \\
\hline Cabin Creek & 1.66 \\
\hline Lima Reservoir & 1.62 \\
\hline Sage Creek & 1.54 \\
\hline Big Sheep Creek & 1.49 \\
\hline Nicholia Creek & 1.49 \\
\hline Upper Horse Prairie Creek & 1.46 \\
\hline Little Sheep Creek & 1.27 \\
\hline Red Rock River & 1.14 \\
\hline Junction Creek & 1.11 \\
\hline Lower Horse Prairie Creek & 1.05 \\
\hline
\end{tabular}

\section{Riparian Grazing Threat Index}

In past watershed assessments, we have calculated a Composite Watershed Condition Index based on multiple threats: residential and recreational development, oil and gas extraction, conversion of prairie grasslands to agriculture, riparian grazing, etc. Energy transmission lines and facilities may be routed through this area in the future, and the area south of Dillon may see some population growth, but neither of these possibilities is certain enough for us to assess the scope of the threat at this time. Similarly, although agriculture and water diversions have certainly affected the natural environment in the past, we do not foresee major new agricultural initiatives or water projects. However, grazing around wetlands and riparian areas is a current threat that we expect will continue. Therefore, we have calculated a Riparian Grazing Threat (IRGT) for the assessment area watersheds.

Cattle grazing can cause soil compaction, nutrient enrichment, vegetation trampling and removal, habitat disturbance, and, depending on the season and intensity of use, reproductive failure for both plants and animals. In riparian areas, grazing can cause stream bank destabilization, loss of riparian shade, and increased sediment and nutrient loads (George et al. 2002). To assess this threat, we used the same 60 meter buffers that we used in the calculation of the riparian loss index. but here we measured the percentage of those buffers which were either under public land ownership (assumed to be available for grazing) or were private but listed in cadastral records as having grazing as a primary use. These buffers are narrow to capture the most intense riparian grazing effects (bank collapse, loss of vegetation filtering function, etc.) and to allow a cross-comparison to the Riparian Loss Index.

The Riparian Grazing Threat Index was then calculated as:

$\mathrm{IGT}=\mathrm{ARG} / \mathrm{ART}$,

where ARG is the area of public and private grazing land in the stream buffers and ART is the total buffer area, in acres. These scores were then relativized by dividing all scores by the highest score.

Table 11 has a breakdown of Riparian Grazing Threat scores for each of the 5 th code watersheds. Two caveats are in order here. First, the scores represent a potential threat, and not necessarily an existing threat. For instance, riparian areas in the Lima Reservoir watershed, which have the highest scores on this metric, are not necessarily in worse 


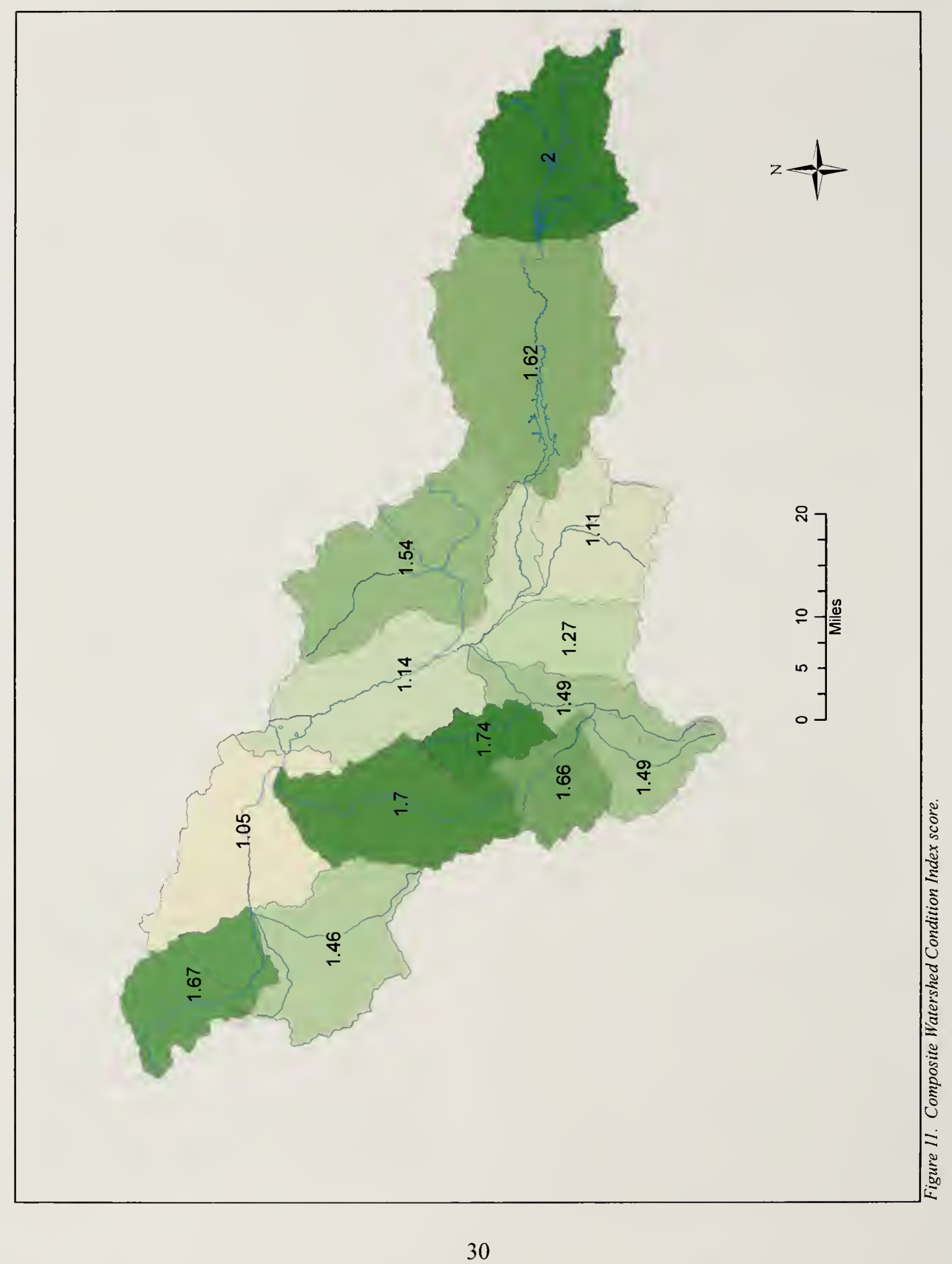


condition than any other 5 th code watershed; management practices may limit riparian grazing, and the land itself may be unsuitable for grazing, or may not be grazed at all. Rural land with no other agricultural use is typically designated as grazing land for tax purposes, regardless of whether it is actually grazed. Moreover, management practices and stocking rates will determine actual condition. Second, scores only indicate potential grazing threats, not impacts that may have already occurred. However, based on our field observations, the two watersheds with the highest scores, Lima Reservoir and Sage Creek, do have widespread grazing. Similarly, the Red Rock River watershed, which had the third highest score on this index, also had a relatively high score on the Riparian Loss lndex, suggesting that grazing may have had negative impacts in the past.

Table 11. Riparian grasing threat index.

\begin{tabular}{|l|c|}
\hline Lima Reservoir & 1.00 \\
\hline Sage Creek & 0.79 \\
\hline Red Rock River & 0.69 \\
\hline Red Rock Lakes & 0.62 \\
\hline Lower Horse Prairie Creek & 0.46 \\
\hline Medicine Lodge & 0.42 \\
\hline Upper Horse Prairie Creek & 0.38 \\
\hline Junction Creek & 0.37 \\
\hline Cabin Creek & 0.26 \\
\hline Bloody Dick Creek & 0.22 \\
\hline Big Sheep Creek & 0.17 \\
\hline Little Sheep Creek & 0.17 \\
\hline Muddy Creek & 0.16 \\
\hline Nicholia Creek & 0.15 \\
\hline
\end{tabular}

\section{Interpreting the Broad-scale Assessment}

\section{Composite Indices}

Although the composite assessment indices could be reduced to a single number, we have kept them separate because each represents a distinct and important piece of the watershed assessment. The Composite Natural Complexity Index provides a basis for assessing the raw material; the range of natural variability within the individual watersheds, which can be used as a surrogate for natural or background conditions. From a management standpoint, watersheds with high natural complexity are those where unique natural features are likely to occur, and may therefore warrant more detailed assessment. The Composite Watershed Condition Index represents overall change in natural conditions, allowing comparisons between individual watersheds and identification of factors that impact overall condition. The Riparian Grazing Threat Index is a measure of what can still be lost. This last index should be interpreted on its own, or at most in relation to the Composite Watershed Condition lndex. For example, the Red Rock Lakes watershed has a high Composite Watershed Condition Index score, but also ranks fairly high on the Riparian Grazing Threat Index. This could indicate that high quality habitat values are at risk of being compromised by grazing, although onsite investigation would be needed to determine if this has been or can be offset by management. By contrast, the Muddy Creek watershed has low Natural Complexity, but a high Watershed Condition Index and a low Riparian Grazing Threat score.

\section{Fine-scale Assessments}

During the summer of 2008 MTNHP wetland ecologists surveyed 103 lentic and lotic sites in the Centennial Valley, using standard BLM protocols (PFC) for assessing function in wetlands and riparian areas. An additional 37 sites were surveyed as part of the aquatic assessments using a separate BLM protocol designed for use in macroinvertebrate-based evaluations; these results are reported separately below.

Of the 103 sites visited by the wetlands team, 83 were on land managed in whole or in part by the BLM; the remainder were on the Red Rock Lakes National Wildlife Refuge. The Centennial Valley was chosen as the focus for these assessments by the BLM field office in Dillon. Unlike the rest of the assessment area, the Centennial Valley is especially rich in wetlands, and wetlands have been mapped as part of the National Wetlands Inventory. Sampling sites were selected by drawing a spatially distributed random sample, stratified by most common wetland classes, from the National Wetlands Inventory. Individual rankings and comments are found in Appendices C-1 to C-3. 
The results are summarized below.

\section{Wetland and Riparian Assessments}

Of the 103 lentic and lotic sites assessed with PFC methodology, we found:

-74 in Proper Functioning Condition;

- 19 Functional at Risk with a downward trend;

-3 Functional at Risk with an undetermined trend;

-7 Nonfunctional.

All lotic sites sampled (8) were in Proper Functioning Condition.

Of 83 sampling sites believed to be or immediately adjacent to BLM-managed lands, we found:

-56 in Proper Functioning Condition with a stable trend;

- 17 Functional at Risk with a downward trend;

- 3 Functional at Risk with an undetermined trend;

.7 Nonfunctional

Overall, we found that the wetlands in the Centennial Valley exhibit a good degree of ecological integrity. Species richness is reasonably high (Appendix D), although most plant communities are dominated by plants with a high tolerance for disturbance. Most of the sites that were found to be in PFC were ranked as A or B in the ecological integrity assessments, and even those sites ranked as FAR were typically ranked $\mathrm{B}$ or C. In almost every case where a wetland was assessed as functional at risk, the reason was hydrologic modification, generally by livestock. With long winters and high moisture, Centennial Valley wetlands tend to have wet soils well into the grazing season, and are especially susceptible to pugging and hummocking . In many of the organic soils found in the Valley and its surroundings, hummocking and pugging create channels that drain water away from the wetlands. In many of these FAR wetlands, the hummocking is so severe that a person cannot walk through the wetland without great difficulty. Although these wetlands still support hydrophilic plants, they are gradually losing their ability to intercept and store surface water, trap sediments, and filter nutrients. If the hummocking and pugging increase, we anticipate loss of function within less than a decade in many cases. We also note that several of the FAR wetlands where we saw severe impacts are fens, a relatively uncommon wetland type in southwestern Montana. In four cases where wetlands were found to be functional at risk, we found that the factors affecting the wetlands were beyond BLM management control. In one case, adjacent private land use is severely impacting a fen (Figure 12); in the other three, the factors ranged from road encroachment to dredging to the effects of drought. Most of the Nonfunctional wetlands were also the result of factors beyond management control: drying out of old beaver ponds, drainage by roads, or succession from wet to dry meadows.

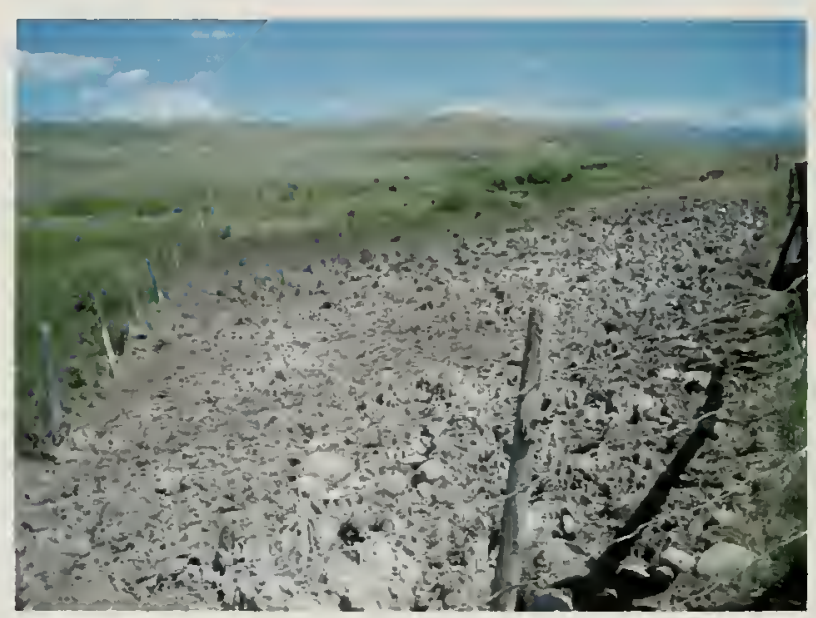

Figure 12. Land use adjacent to a fen.

In our initial wetland sample draw, we identified 100 wetlands from the National Wetlands Inventory mapping. Less that 80 of these were wetlands when we located them. In most cases, we attributed this to mapping errors: sites were more mesic than wet. In other cases, the loss appeared to be attributable to drought rather than to human factors, although soil compaction and heavy grazing may have played a factor in some instances. We also noted that in general, invasive weeds are not common in assessment area. Canada thistle (Cirsium arvense) was the most common invasive. However, exotic grasses such as Kentucky bluegrass and smooth brome (Bromus inermis) have become widespread, and appear to be outcompeting native species in many riparian areas. 


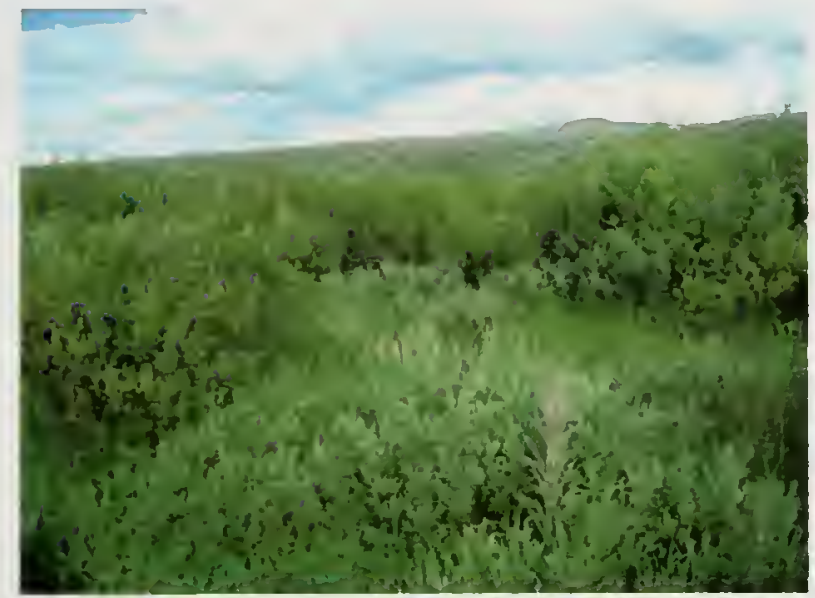

Figure 13. A proper functioning condition riparian site.

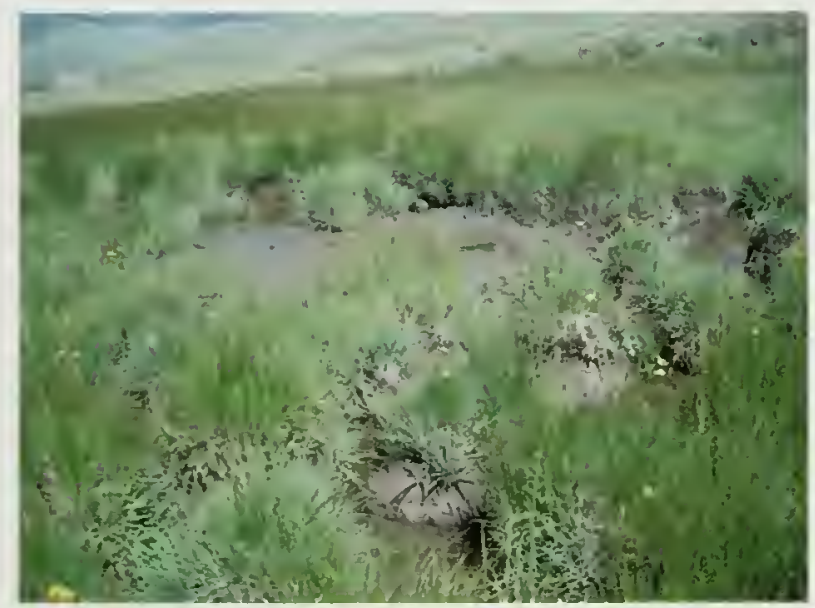

Figure 14. A functional at risk site with a downward trend.

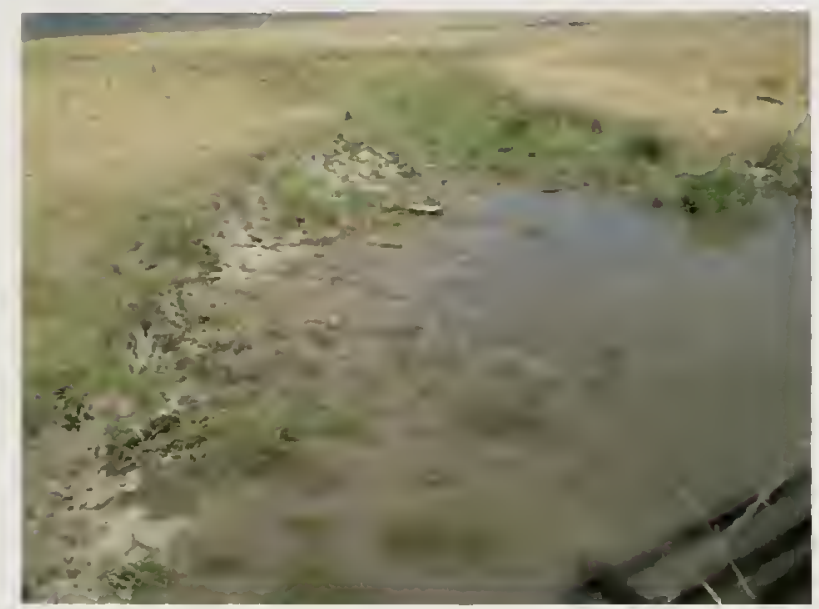

Figure 15. A nonfunctional site.

In areas where cattle congregate or loaf along stream banks, we saw bare batches and examples of bank sheer. Still, in areas where grazing is light and water supplies are abundant, willows are wellestablished along most of the perennial creeks, and recruitment is generally good. Browsing by all species --cattle, moose and elk-- appears to be relatively limited.

\section{Aquatic Assessments}

As a second component of our fine-scale assessment work, we sampled and assessed aquatic community integrity based on macroinvertebrate and habitat sampling at lotic sites near where PFC assessments were carried out. Our goal was to identify and interpret key community indicators found at the sites using standardized protocols and biotic thresholds, and compare these against reference condition standards at the watershedlevel and local-reach scale.

On-site habitat assessments were conducted using the rapid assessment protocol by the National Aquatic Assessment of the Bureau of Land Management (BLM) Buglab (scores 0-24) (http://www l.usu.edu/buglab/forms/ Bug\%20Protocol\%20form.pdf). Following the BLM assessment protocols, the reach was divided into ten equally spaced transects. At each transect, we measured wetted width, bankfull width, channel depth at three locations, and amount of large woody debris and riparian shading. Basic water chemistry parameters (temperature, $\mathrm{pH}$, conductivity, dissolved $\mathrm{O}^{2}$ ) were recorded prior to sampling at the downstream end of the reach using a Horiba $\mathrm{H}-10$ water monitor. These measurements allow characterization of local reach geomorphology, riparian and in-stream habitat, and other qualities that influence aquatic community integrity. Sites ranking higher using these protocols are determined to have higher quality local-scale habitat. Habitat assessments were performed during the same visit as the biological sampling. Habitat assessment scores greater than 20 are considered intact and properly functioning, while those with scores at or below 20 have one or more habitat / riparian impairments.

Macroinvertebrates were collected in lotic sites from 10 evenly spaced transects across the reach with a 500-micron D-frame net. The method utilized was the EPA EMAP_Reach-Wide Multi- 
habitat protocol outlined in Lazorchak et al. (1998). All 10 samples taken within the designated transects were composited into a bucket, and the organisms were washed onto a 500-micron sieve, transferred to a one liter Nalgene bottle, labeled and preserved in $95 \%$ ethanol, and brought to the MTNHP lab in Helena for processing. Lentic site macroinvertebrates were sampled using the multi-habitat, dipnet protocols outlined in the EPA RBP Assessment Manual (Barbour et al. 1999). This involved $20(1 / 2 \mathrm{~m})$ dipnet jabs partitioned in accordance to the dominant habitat types of the wetland (i.e., emergent vegetation, submerged vegetation, unconsolidated bottom, etc.). These samples were processed (sorting, identification, and data analysis) by David Stagliano at the Helena NHP lab. Processing of samples from lotic sites followed MT Department of Environmental Quality's protocols (MT DEQ 2005). Macroinvertebrates were identified to the lowest taxonomic level, and data were imported into EDAS (Jessup 2006). Biological metrics were calculated from the data using the newest multimetric macroinvertebrate (MMI) protocols (Jessup et al. 2005, Feldman 2006). The macroinvertebrate MMI score is based upon a series of metrics that measure attributes of benthic macroinvertebrate communities that are sensitive to anthropogenic changes in streams and rivers. There are currently no MT DEQ or EPA approved metrics for wetland macroinvertebrate assessments, so interpretation of invertebrate samples from lentic sites was largely informed by best professional judgment, given knowledge of expected communities, individual taxon tolerances, and assemblage metrics known to respond to anthropogenic stressors (species richness, taxa dominance, etc.) (Barbour et. al. 1999). We also analyzed a subset of lentic samples with the macroinvertebrate MMI to determine whether metrics developed for lotic sites might provide useful information. For both lentic and lotic sites, metric results were scored using the Montana DEQ bioassessment criteria and each sample was categorized as non-impaired or impaired according to threshold values (Table 12). The impairment threshold set by MT DEQ is 63 for the Mountain Stream Index, and 48 for the Low Mountain/ Valley Index; any scores above this threshold are considered unimpaired. Although all lotic sites in the Centennial Assessment Basin fall within the mountain elevation class, the streams themselves have characteristics of the Foothills/Valleys ecoregion and the Small Foothills River Aquatic Ecological System (AES C001). Consequently, both MMI scores are reported and interpreted. We caution the reader to evaluate these scores in the context of the habitat assessments performed for this part of the study. Because of the mix of mountain and foothill features, the MMI FV may assign some mildly impaired Mountain streams an unimpaired score, while the Mountain MMI may falsely assign impaired rankings to unimpaired Foothills streams.

In our analysis of habitat condition, we found that 14 of the $37(38 \%)$ aquatic assessment wetland sites had good habitat quality (i.e., Proper Functioning Condition) ranked by at least one of the habitat assessment methods (Table 13). Twenty of the sites (54\%) were ranked impaired (Functional At Risk); six of these had a downward trend and four appeared to be improving. Three sites were impaired to the point of being Nonfunctional wetlands ( $8 \%$ ). Highest site habitat scores using both BLM habitat assessment methods were measured at West Fork Corral Creek, where we sampled 3 lotic sites and 1 lentic wetland. Highest deductions to the riparian assessment scores were in stream sediments, bare ground, and

Table 12. Impairment determinations from the MMI.

\begin{tabular}{|l|l|l|l|l|}
\hline Ecoregion & RIVPACS & MMI & Impairment Determination \\
\hline Mountain & $>0.8$ or $<1.2$ & $>63$ & Not impaired \\
\hline & $<0.8$ or $>1.2$ & $<63$ & Impaired \\
\hline & & & \\
\hline Low Valley & $>0.8$ or $<1.2$ & $>48$ & Not impaired \\
\hline & $<0.8$ or $>1.2$ & $<48$ & Impaired \\
\hline
\end{tabular}


Table 13. Centennial lallev dragonfly and damselfty species.

\begin{tabular}{|c|c|c|c|c|c|c|c|c|c|c|c|c|c|c|c|c|}
\hline & 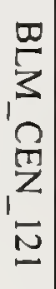 & 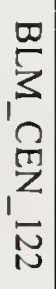 & 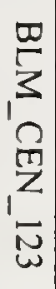 & $\begin{array}{c}\frac{\square}{5} \\
3 \\
1 \\
\frac{\pi}{Z} \\
1 \\
\overline{ \pm}\end{array}$ & $\begin{array}{l}\frac{\infty}{2} \\
\frac{1}{2} \\
\frac{\pi}{2} \\
\frac{\pi}{2}\end{array}$ & 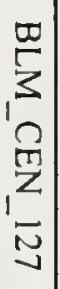 & 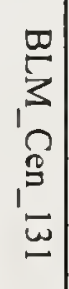 & 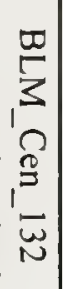 & 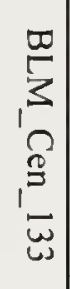 & 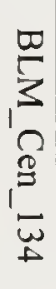 & 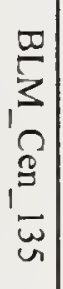 & 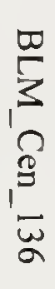 & 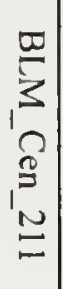 & 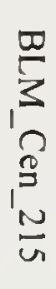 & 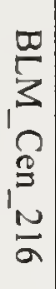 & 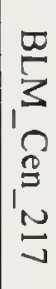 \\
\hline \multicolumn{17}{|l|}{ Damselflies } \\
\hline Argia (Larvae) & & & & & & & & & & & $\mathrm{X}$ & $\mathrm{X}$ & & & & \\
\hline Amphiagrion abbreviatum & & & & & & & & & & & & $X$ & & & & \\
\hline Lestes congener & $X$ & & & & $\mathrm{X}$ & & $\mathrm{X}$ & $\mathrm{X}$ & $\mathrm{X}$ & & & & & $\mathrm{X}$ & & \\
\hline Lestes disjunctus & $\mathrm{X}$ & $\mathrm{X}$ & & & $\mathrm{X}$ & & $\mathrm{X}$ & $\mathrm{X}$ & $\mathrm{X}$ & & & & & $\mathrm{X}$ & & \\
\hline Lestes dryas & & $\mathrm{X}$ & $\mathrm{X}$ & $\mathrm{X}$ & & & & & & & & & & & & \\
\hline Enallagma (Larvae) & & $\mathrm{X}$ & & & $\mathrm{X}$ & & $\mathrm{X}$ & & $X$ & & & $\mathrm{X}$ & & $\mathrm{X}$ & $\mathrm{X}$ & $\mathrm{X}$ \\
\hline Enallagma annexum & & $\mathrm{X}$ & $\mathrm{X}$ & & & $\mathrm{X}$ & $\mathrm{X}$ & $\mathrm{X}$ & $\mathrm{X}$ & $\mathrm{X}$ & & & & & $\mathrm{X}$ & \\
\hline Enallagma boreale & & $\mathrm{X}$ & $\mathrm{X}$ & $\mathrm{X}$ & & & & & $\mathrm{X}$ & & & & & & & \\
\hline \multicolumn{17}{|l|}{ Dragonflies } \\
\hline Aeshma constricta & & $\mathrm{X}$ & & & & & $\mathrm{X}$ & $\mathrm{X}$ & & & & & & & & \\
\hline Aeshna palmata & & $\mathrm{X}$ & $\mathrm{X}$ & $\mathrm{X}$ & $\mathrm{X}$ & $\mathrm{X}$ & & & $\mathrm{X}$ & & & & & & & \\
\hline Aeshna interrupta & & & & & $X$ & & & & & & & & & & & \\
\hline Sympetrum (Larvae) & & & & & & & $\mathrm{X}$ & $\mathrm{X}$ & & & & & & & & \\
\hline Sympetrum internum & $\mathrm{X}$ & & & & $\mathrm{X}$ & & $\mathrm{X}$ & $\mathrm{X}$ & $\mathrm{X}$ & $\mathrm{X}$ & $\mathrm{X}$ & & & & & \\
\hline Sympetrum danae & & & & & & & $\mathrm{X}$ & $\mathrm{X}$ & $\mathrm{X}$ & & & & & & & \\
\hline Sympetrum pallipes & & & & & & & $\mathrm{X}$ & $\mathrm{X}$ & $\mathrm{X}$ & & & & & & & \\
\hline Lencorrhinia proxima & & & & & & & $\mathrm{X}$ & $\mathrm{X}$ & $\mathrm{X}$ & & & & & & $\mathrm{X}$ & $\mathrm{X}$ \\
\hline Ophiogomphus severus & & & & & & & & & & & $\mathrm{X}$ & & & & & \\
\hline Somatochlora semicircularis & & & & & & & & & & & & & $\mathrm{X}$ & & & \\
\hline Total Odonata & 3 & 6 & 4 & 3 & 6 & 2 & 10 & 9 & 10 & 2 & 3 & 3 & 1 & 3 & 3 & 2 \\
\hline
\end{tabular}

bank trampling by cattle intrusions into the riparian zone. These intrusions were specifically measured using the Livestock Use Index (LUI), which was very high for multiple streams and wetlands including East Fork Corral Creek and wetlands in the West Creek.

Overall, 118 macroinvertebrate taxa were reported from the BLM 2008 aquatic assessment sites. Average macroinvertebrate taxa richness per site was 22 , and the highest taxa richness reported at 2 sites was 46 taxa. Using the Montana DEQ FV MMl. 15 of the 16 lotic sites sampled were ranked non-impaired (good to excellent biological integrity) and I was slightly impaired. Using the DEQ Mountain MMI, 6 of 15 were nonimpaired, 5 slightly impaired and 4 moderately to severely impaired. The Foothills MMI may not be as sensitive to degraded conditions and changing macroinvertebrate communities. The macroinvertebrate communities ranked with the mountain MMl index seemed to correlate with riparian condition better, with slightly impaired macroinvertebrate communities reported more often at riparian areas ranked FAR. However, no significant relationship was detected between the lotic BLM Habitat Assessment Scores and either the DEQ MT MMI or FV metric scores (Figure 16). In fact, two of the highest macroinvertebrate MMI Scores $(>70)$ were collected from lotic 


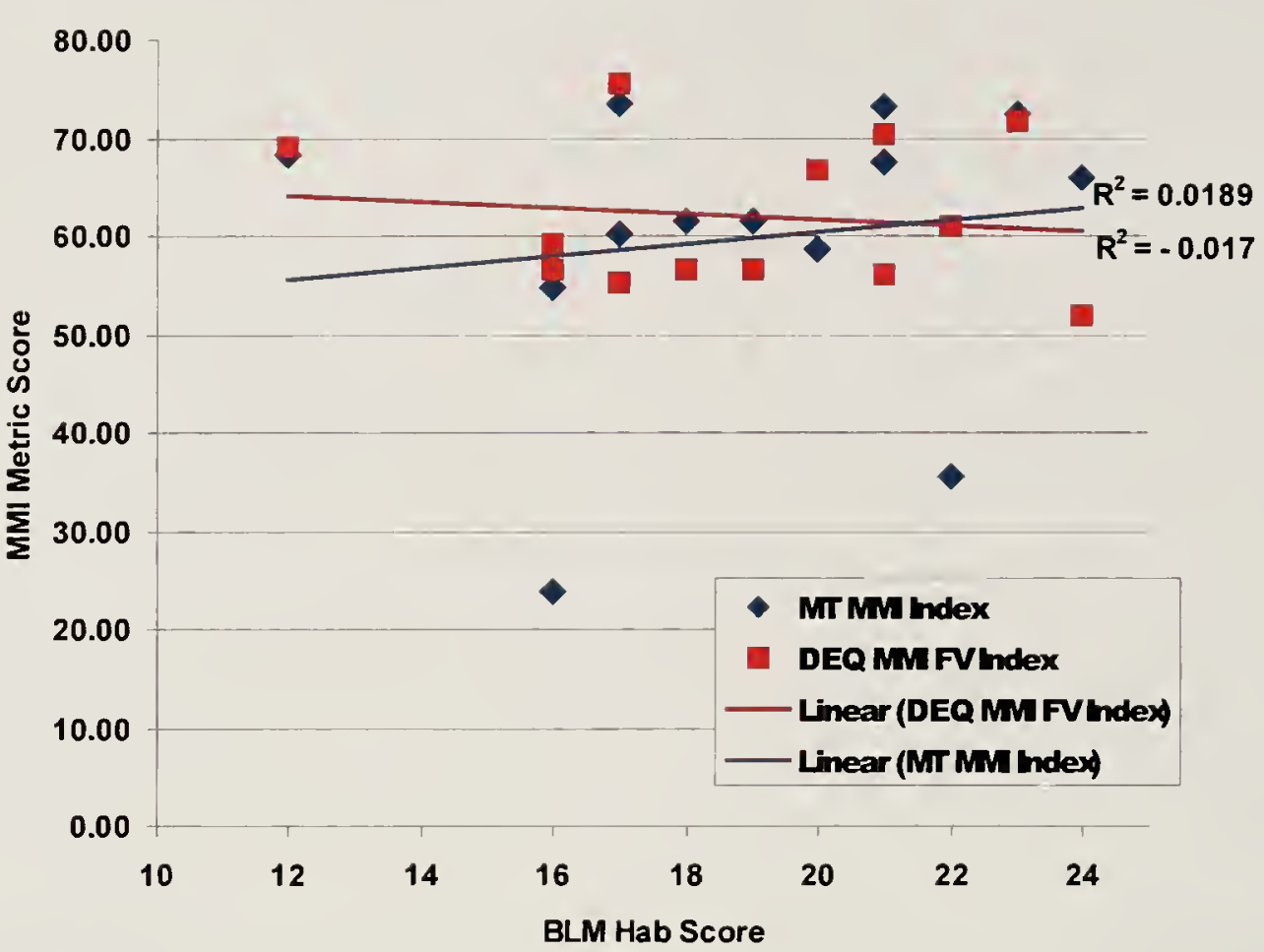

Figure 16. MMII scores vs. BLM habitat score (functional condition).

systems with moderately (HBI-17) to severely degraded (HBl-12) riparian and in-stream habitat conditions. Price Creek seems to be improving in biotic integrity; it was rated as slightly impaired in 2004 at a DEQ site sampled, and as unimpaired in our survey (MMI scores 45.5 (2004) to 66.8 (2008).

As an indicator of lentic wetland macroinvertebrate condition, the mountain macroinvertebrate MMI consistently ranked all sites as impaired whether they were properly functioning or not. The FV MMl tracked wetland condition fairly well, ranking 4 out of 5 PFC sites as unimpaired and 2 of 2 FAR sites as having slightly impaired macroinvertebrate communities. The use of dragonfly metrics has been proposed in wetland assessments based on increased species richness with aquatic habitat complexity. However, although we found several dragonfly and damselfly species at the assessment sites (Table 13), we found no significant difference between dragonfly species richness and different riparian functional condition
(T test, $\mathrm{p}=\mathbf{0 . 4 9 5 )}$ (Figure 17).

Based on these assessments, we ranked aquatic sites from highest to lowest integrity by Aquatic Ecological System (AES) as follows:

-Intermountain Transitional River (AES B003)-

1) Red Rock River (slightly impaired)

-Small Foothills River (AES C001)-1) West Fork Corral Creek, 2) East Fork Corral Creek, 3) Price Creek, 4) Pete Creek, 5) Price Creek, 6) West Creek

- Centennial Basin Perennial Spring (AES code S005)- 1) BLM Spring \#136

\section{Relationship Between Broad-scale and Fine-scale Assessments}

In most cases, broad-scale assessments provide insight into cumulative impacts on wetland and aquatic ecosystems, while fine-scale assessments 


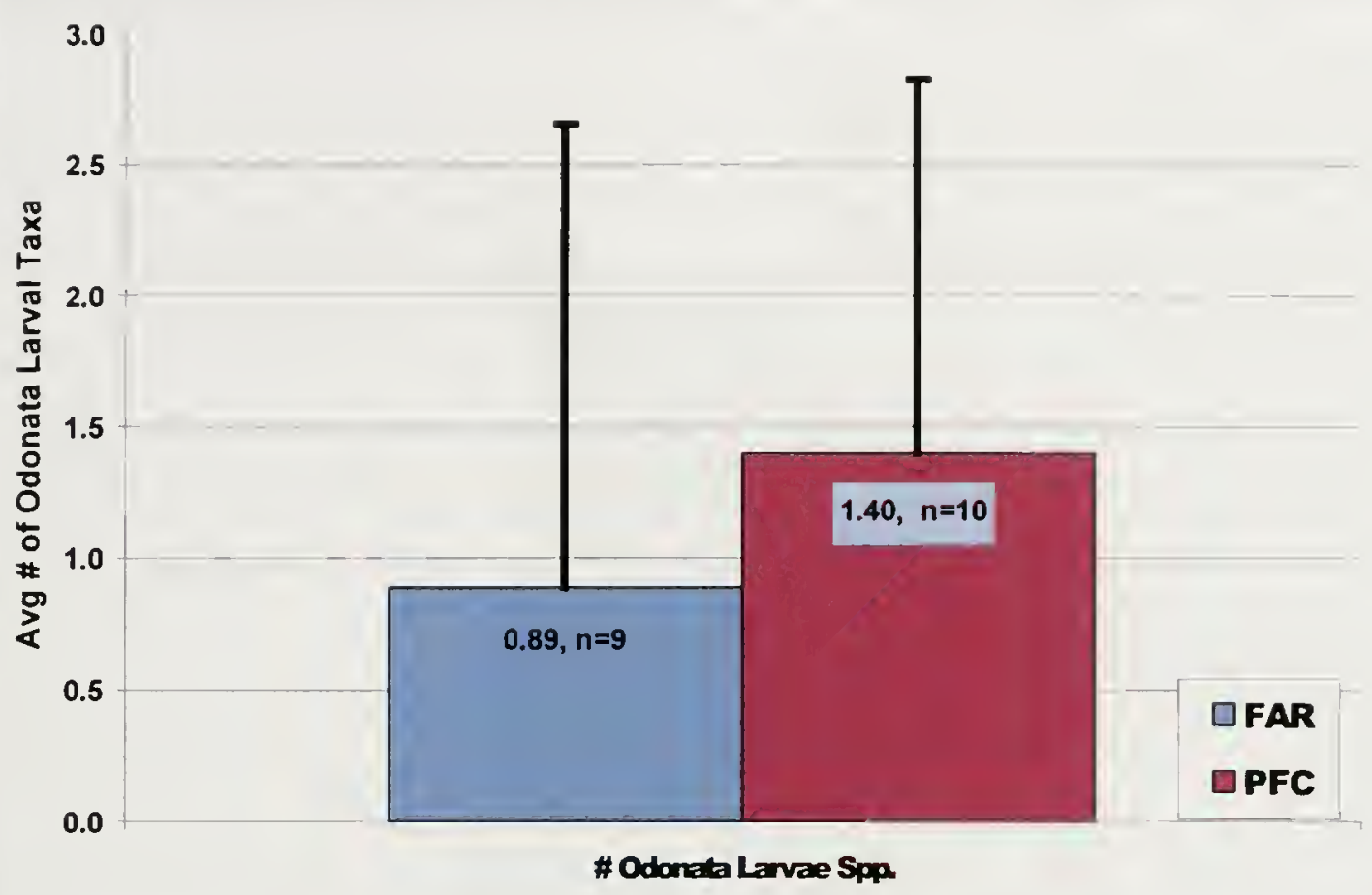

Figure 17. Odonata larval species richness by functional condition.

measure cumulative effects (Johnson 2005). Impacts may occur at a significant distance from their effects, as is often the case with upstreamdownstream relationships observed in aquatic systems, or they may occur in close proximity. For example, impacts from land use activities in upstream watersheds may have effects downstream. Typically, the value of watershed-level assessments lies in identifying areas where impacts are currently occurring or may occur, rather than merely documenting effects that have already occurred. By combining both site-level and watershed-level assessments, it is possible to select areas where management can make a substantial difference in future wetland and aquatic health. Even when there are similar findings between the two levels of assessment, they need to be examined less for correlation than for the different perspectives they provide.

In this case, the correlation is quite pronounced. In our broad-scale assessment, both the Red Rock Lakes and Lima Reservoir watersheds had the highest overall scores on the Composite Natural Complexity, indicating similarities in baseline condition. However, the Red Rock Lakes watershed had a markedly higher score on the Composite Wetland Condition Index, suggesting that impacts were occurring across a broad scale. This is borne out by the fine-scale assessments. As can be seen in Figure 18, the wetlands assessed in the Red Rock Lakes watershed were mostly in Proper Functioning Condition, while many of the wetlands in the Lima Creek Reservoir watershed showed some level of impairment.

From our field surveys, it appears that landscape level stressors and site-specific stressors are related in these two watersheds. The Red Rock Lakes watershed is the more remote of the two, has fewer roads, and has been grazed less intensively over the past decades. The Lima Creek Reservoir watershed, by contrast, has more private land and more livestock operations, and consequently more roads to facilitate the movement of cattle. As noted above, most of the functional impairments we observed were associated with the timing and/or intensity of livestock use. On the positive side, however, this provides clear management opportunities for the BLM. 


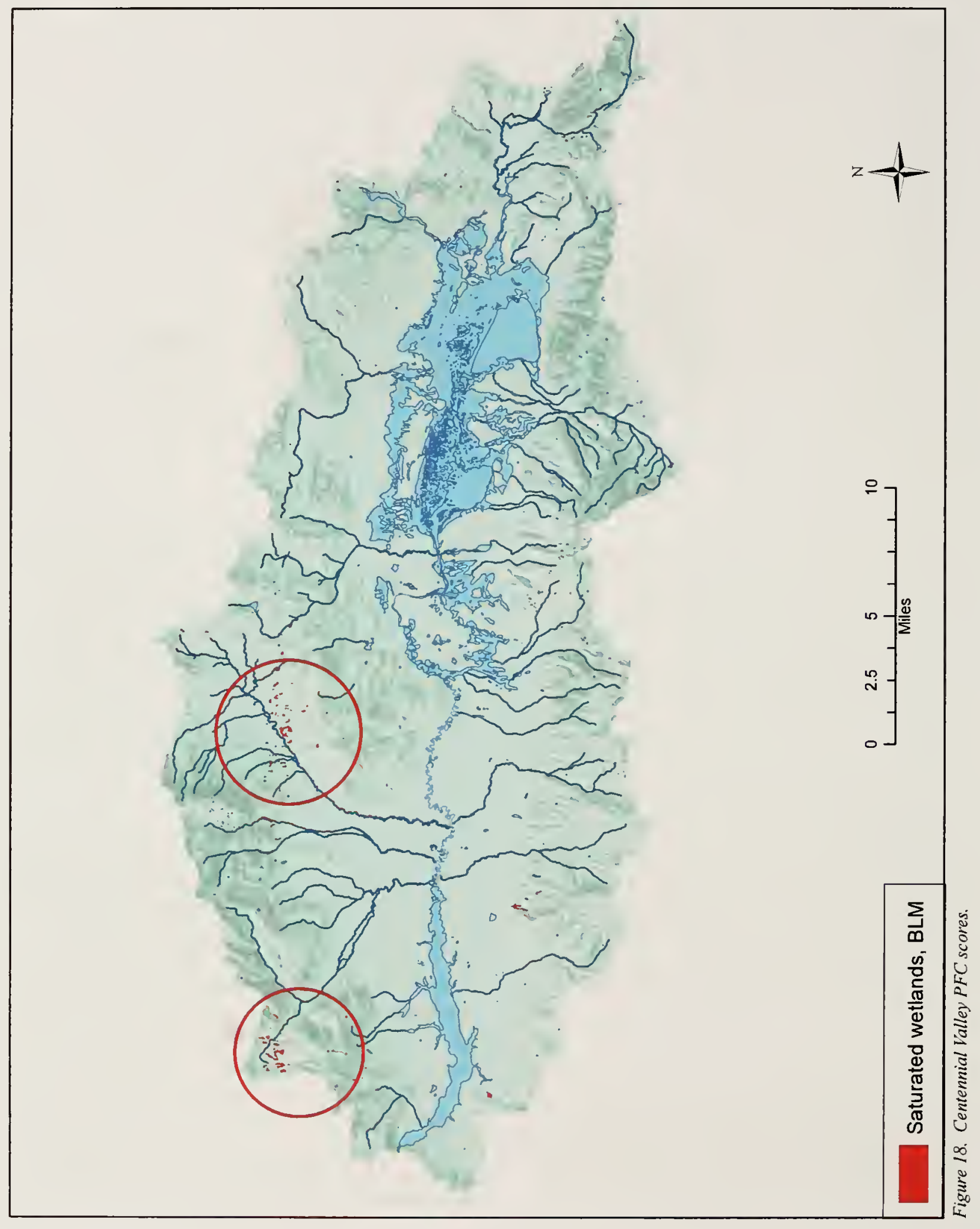




\section{Management Opportunities}

The BLM owns and administers a substantial proportion of land within the assessment area. and can play an important role in conserving or restoring natural functioning. Based on our broadscale and fine-scale assessments in the Centennial Valley, we think that grazing management provides the best opportunity for protecting and restoring wetland function. Although wetlands and some riparian areas have been negatively impacted by grazing, our field surveys indicated that rangelands across the assessment area are in generally good to very good condition, and reflect conscientious grazing management.

In an area rich with wetlands, general exclusion of cattle through fencing is impractical. We would recommend instead that the BLM carry out wetland landscape profiling and targeted surveys to identify specific examples of sensitive wetland habitats, and develop grazing management strategies on a case-by-case basis. For example, we used a GIS to identify NWI-mapped wetlands with a "saturated" designation (PEMB or PSSB) on BLM lands in the Centennial Valley. These saturated wetlands are often fens or carrs, which are noted for their high diversity and potential for rare plant occurrences. Figure 19 shows two distinct clusters of saturated wetland along Long Creek and Clover Creek, with other examples scattered throughout Centennial Valley BLM lands. Inspection of these areas on aerial photos, followed by field evaluation, could determine if these areas are indeed significant wetlands in good or restorable condition. If this is the case, exclusion might be warranted. A similar exercise could identify seasonally flooded wetlands, where soils are more sensitive to grazing disturbance in the spring than later in the season. If there are concentrations of high-quality seasonally flooded wetlands, then grazing plans limiting early season access would be a good protection strategy. These management practices, coupled with frequent utilization monitoring, would provide effective protection of wetland functions and values in the area. 


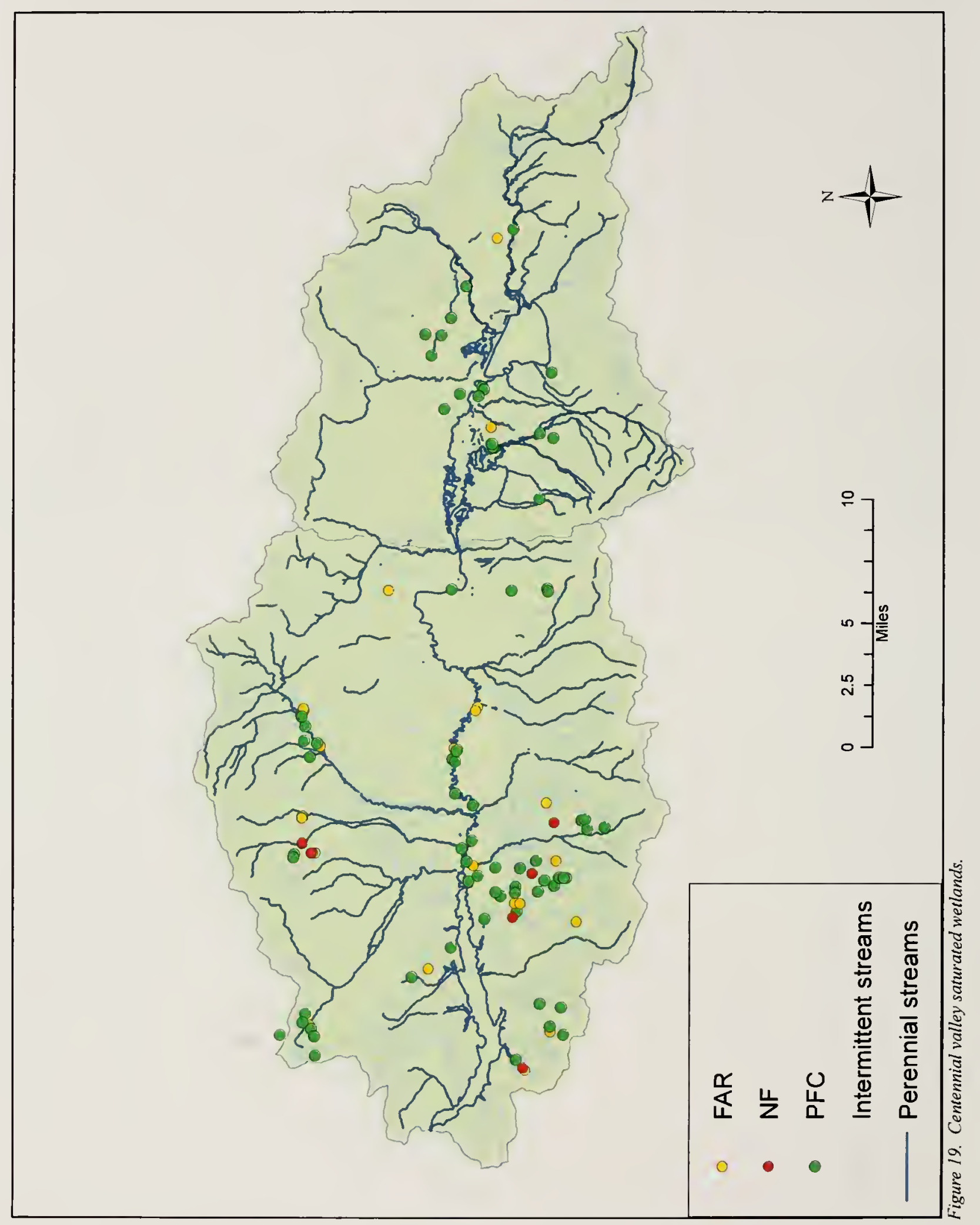




\section{Literature Cited}

Barbour, M., J. Gerritsen, B.D. Snyder, and J.B. Stribling. 1999. Rapid Bioassessment Protocols For Use In Streams And Wadable Rivers: Periphyton, Benthic Macroinvertebrates And Fish. Second Edition. Epa 841-B-99-002. United States Environmental Protection Agency; Office of Water: Washington, D.C.

BLM Dillon Field Office. 2007. Red Rock and Lima Watershed Assessment. Dillon, MT. Available at: http://www.blm.gov/mt/en/fo/dillon field office/redrock.html.

Comer, P., D. Faber-Langendoen, R. Evans, S. Gawler. C. Josse, G. Kittel, S. Menard, M. Pyne, M. Reid, K. Schulz, K. Snow, and J. Teague. 2003. Ecological Systems of the United States: A Working Classification of U.S. Terrestrial Systems. NatureServe, Arlington, Virginia. $83 \mathrm{pp}$.

Crowe, E. and G. Kudray. 2003. Wetland Assessment of the Whitewater Watershed. Report to U.S. Bureau of Land Management, Malta Field Office. Montana Natural Heritage Program, Helena, MT. 34 pp. plus appendices.

Cowardin L.M., V. Carter, F.C. Golet and E.T LaRoe. 1979. Classification Of Wetlands And Deepwater Habitats of The United States. USFWS, Office of Biol. Ser. (FWS/OBS-79/31), December 1979. $103 \mathrm{pp}$.

Dorn, R. D. 1984 . Vascular Plants of Montana. Mountain West Publishing, Cheyenne, WY. $276 \mathrm{pp}$.

Feldman. D. 2006. Interpretation of New Macroinvertebrate Models by WQPB. Draft Report. Montana Department of Environmental Quality, Planning Prevention and Assistance Division, Water Quality Planning Bureau, Water Quality Standards Section. 1520 E. $6^{\text {th }}$ Avenue, Helena, MT 59620. 14 pp.
George, M.R., R.E. Larsen, N.K. McDougald, K.W. Tate, J.D. Gerlach, Jr., and K.O. Fulgham. 2002. Influence of grazing on channel morphology of intermittent streams. J. Range Management. 55:551-557.

Great Plains Flora Association. 1977. Atlas of the Flora of the Great Plains. lowa State Univ. Press, Ames.

Great Plains Flora Association. 1986. Flora of the Great Plains. University Press of Kansas. Lawrence, KS. 1392 pp.

Hansen, Paul L., R. D. Pfister, K. Boggs, B. J. Cook, J.Joy, and D.K. Hinckley. 1995. Classification and Management of Montana's Riparian and Wetland Sites. Miscellaneous Publication No. 54. School of Forestry, University of Montana, Missoula, MT.

Hauer, F. R., B.J. Cook, M.C. Gilbert, E.C. Clairain, Jr., and R.D. Smith. May 2002. A Regional Guidebook for Applying the Hydrogeomorphic Approach to Assessing Wetland Functions of Intermontane Prairie Pothole Wetlands in the Northern Rocky Mountains. Special Publication ERDC/EL TR-02-7. WES, USCOE, Vicksburg, MS. $118 \mathrm{pp}$. plus appendices.

Hendricks, P. and M. Roedel. 2001. A Faunal Survey Of The Centennial Valley Sandhills, Beaverhead County, Montana. Report to the U.S. Bureau of Land Management and U.S. Fish and Wildlife Service. Montana Natural Heritage Program, Helena, MT. 44 pp.

Heidel, B. and E. Rodemayer. 2008. Inventory of Peatland Systems in the Beartooth Mountains. Report to the Environmental Protection Agency. Wyoming Natural Diversity Database, Laramie, WY. $43 \mathrm{pp}$. 
Jean, C., P. Hendricks, M. Jones, S.V. Cooper and J. Carlson. 2002. Ecological Communities on the Red Rocks Lakes National Wildlife Refuge: Inventory and Review of Aspen and Wetland Systems. Report to the Red Rock Lakes National Wildlife Refuge. Montana Natural Heritage Program, Helena, Montana. 33 pp. plus appendices.

Jessup, B., J. Stribling; and C. Hawkins. 2005. Biological Indicators of Stream Condition in Montana Using Macroinvertebrates. Tetra Tech, Inc. November 2005 (draft).

Jessup, B. 2006. Ecological Data Application System (EDAS) Version MT 3.3.2k A User's Guide. Tetra Tech, Inc.

Kartesz, J.T. 1999. A synonymized checklist and atlas with biological attributes for the vascular flora of the United States, Canada, and Greenland. In J.T. Kartesz and C.A. Meacham, editors. Synthesis Of The North American Flora, Version 1.0. North Carolina Botanical Garden, Chapel Hill, North Carolina.

Lazorchak, J.M., Klemm, D.J., and D.V. Peck (editors). 1998. Environmental Monitoring and Assessment Program - Surface Waters: Field Operations and Methods for Measuring the Ecological Condition of Wadeable Streams. EPA/620/R-94/004F. U.S. Environmental Protection Agency, Washington, D.C.

Mueggler, W.F. 1988. Aspen Community Types Of The Intermountain Region. USDA Forest Service General Technical Report INT-250. Intermountain Research Station, Ogden, Utah. $135 \mathrm{pp}$.

Moyle, P.B. and M.P. Marchetti. 1999. Applications of indices of biotic integrity to California streamsand watersheds. Pages 367-382 in T.P. Simon, editor. Assessing The Sustainability And Biological Integrity Of Water Resources Using Fish Communities. CRC Press, Boca Raton, FL 671 pp.
Omernik, J.M. 1987. Ecoregions of the conterminous United States (map supplement). Annals of the Association of American Geographers, $\mathrm{v}$. 77 , no. 1, p.118-125, scale 1:7,500,000.

Power, M.E. G. Parker, W.E. Dietrich, and A. Sun. 1995. How does floodplain width affect floodplain river ecology? A preliminary exploration using simulations. Geomorphology 13: 301317.

Pritchard, D., F. Berg, W. Hagenbuck, R. Krapf, R. Leinard, S. Leonard, M. Manning, C. Noble, and J. Staats. 1999. Riparian Area Management: A User Guide To Assessing Proper Functioning Condition And The Supporting Science For Lentic Areas. Technical Reference 173716. USDI Bureau of Land Management Service Center. Denver, Colorado. USA. 109 pp.

Tiner, R., M. Starr, H. Bergquist, and J. Swords. 2000. Watershed-Based Wetland Characterization For Maryland's Nanticoke River And Coastal Bays Watersheds: A Preliminary Assessment Report. U.S. Fish \& Wildlife Service, National Wetlands Inventory (NWI) Program, Northeast Region, Hadley, MA. Prepared for the Maryland Department of Natural Resources, Coastal Zone Management Program (pursuant to National Oceanic and Atmospheric Administration award). NWI technical report.

Vance, L.K. 2005. Watershed Assessment Of The Cottonwood And Whitewater Watersheds. Report to the Bureau of Land Management. Montana Natural Heritage Program, Helena, MT. 57 pp. plus appendices.

Vance, L., D. Stagliano, and G. M. Kudray. 2006. Watershed Assessment of the Middle Powder Subbasin, Montana. A Report To The Bureau Of Land Management, Montana State Office. Montana Natural Heritage Program, Helena, Montana. $61 \mathrm{pp}$. plus appendices. 
Vance, Linda K. and David M. Stagliano. 2007.

Watershed Assessment of Portions of the Lower Musselshell and Fork Peck Reservoir Subbasins. Report to the Bureau of Land Management. Lewistown Ficld Office. Montana Natural Heritage Program, Helena. Montana. 41 pp. plus appendices.

Vance. Linda K. and David M. Stagliano. 2008. Watershed Assessment of Portions of the Clark's Fork Yellowstone. Bighhorn Lake, and Shoshone Subbasins. Montana and Wyoming. Report to the Bureau of Land Management, Montana / Dakotas State Offices. Montana Natural Heritage Program. Helena, Montana. $45 \mathrm{pp}$. plus appendices.

Vance, Linda K. 2009. Assessing Wetland Condition with GIS: A Landscape Integrity Model for Montana. A Report to The Montana Department of Environmental Quality and The Environmental Protection Agency. Montana Natural Heritage Program, Helena, MT. 23 pp. plus appendices.

Wilkin, D.C., and S.J. Hebel. 1982. Erosion, redeposition and delivery of sediment to Midwestern streams. Water Resources Research (18)4 pp. 1278-1282. 


\section{Appendix A. Montana Species of Concern in the Assessment Area}




\begin{tabular}{|c|c|}
\hline Scientific Name & Comnion Name \\
\hline \multicolumn{2}{|l|}{ Amphibians } \\
\hline Bufo boreas & Western Toad \\
\hline \multicolumn{2}{|l|}{ Birds } \\
\hline Accipirer gentilis & Northern Goshawk \\
\hline Aechmophorus clarkii & Clark’s Grebe \\
\hline Ammodramus salamarum & Grasshopper Sparrow \\
\hline Amphispiza belli & Sage Sparrow \\
\hline Aquila chrysaetos & Golden Eagle \\
\hline Ardea herodias & Great Blue Heron \\
\hline Asio flamments & Short-eared Owl \\
\hline Athene cunicularia & Burrowing Owl \\
\hline Botaurus lentiginosus & American Bittern \\
\hline Bucephala islandica & Barrow's Goldeneye \\
\hline Buteo regalis & Ferruginous Hawk \\
\hline Buteo swainsoni & Swainson's Hawk \\
\hline Calcarius mecownii & McCown's Longspur \\
\hline Carpodacus cassinii & Cassin's Finch \\
\hline Catharus fuscescens & Veery \\
\hline Centrocercus urophasianus & Greater Sage-Grouse \\
\hline Certhia americana & Brown Creeper \\
\hline Chlidonias niger & Black Tern \\
\hline Coturnicops noveboracensis & Yellow Rail \\
\hline Cygmus buccinator & Trumpeter Swan \\
\hline Empidonax alnorum & Alder Flycatcher \\
\hline Falco peregrinus & Peregrine Falcon \\
\hline Gavia immer & Common Loon \\
\hline Grus americana & Whooping Crane \\
\hline Haliacetus lencocephalus & Bald Eagle \\
\hline Himantopus mexicanus & Black-necked Stilt \\
\hline Histrionicus histrionicus & Harlequin Duck \\
\hline Hydroprogne caspia & Caspian Tern \\
\hline Leucophaeus pipixcan & Franklin`s Gull \\
\hline Leucosticte atrala & Black Rosy-Finch \\
\hline Lencosticte tephrocotis & Gray-crowned Rosy-Finch \\
\hline Lophodytes cucullatus & Hooded Merganser \\
\hline Melanerpes lewis & Lewis's Woodpecker \\
\hline Mniotilta varia & Black-and-white Warbler \\
\hline Nucifraga columbiana & Clark's Nutcracker \\
\hline Numenius americanus & Long-billed Curlew \\
\hline Nycticorax nycticorax & Black-crowned Night-Heron \\
\hline
\end{tabular}




\begin{tabular}{|c|c|}
\hline Oreoscoptes montamis & Sage Thrasher \\
\hline Otus flammeolus & Flammulated Owl \\
\hline Pelecamus erythrorhynchos & American White Pelican \\
\hline Picoides arcticus & Black-backed Woodpecker \\
\hline Plegadis chihi & White-faced Ibis \\
\hline Podiceps auritus & Horned Grebe \\
\hline Selasphorus platycercus & Broad-tailed Hummingbird \\
\hline Selasphorus rufus & Rufous Hummingbird \\
\hline Spizella breweri & Brewer's Sparrow \\
\hline Stema forsteri & Forster's Tern \\
\hline Sterna hirundo & Common Tern \\
\hline Strix nebulosa & Great Gray Owl \\
\hline Troglodytes troglodytes & Winter Wren \\
\hline \multicolumn{2}{|l|}{ Fish } \\
\hline Lota lota & Burbot \\
\hline Oncorhynclus clarkii bouvieri & Yellowstone Cutthroat Trout \\
\hline Oncorlynchus clarkii lewisi & Westslope Cutthroat Trout \\
\hline Salvelimus namorycush & Lake Trout \\
\hline Thymallus arcticus & Arctic Grayling \\
\hline \multicolumn{2}{|l|}{ Mammals } \\
\hline Brachylagus idahoensis & Pygmy Rabbit \\
\hline Canis lupus & Gray Wolf \\
\hline Conynorhinus townsendii & Townsend's Big-eared Bat \\
\hline Gulo gulo & Wolverine \\
\hline Lasionycteris noctivagans & Silver-haired Bat \\
\hline Lasiurus cinereus & Hoary Bat \\
\hline Lepus califomicus & Black-tailed Jack Rabbit \\
\hline Lynx camadensis & Canada Lynx \\
\hline Marmota caligata & Hoary Marmot \\
\hline Myotis thysanodes & Fringed Myotis \\
\hline Perognathus parvus & Great Basin Pocket Mouse \\
\hline Sorex merriami & Merriam`s Shrew \\
\hline Sorex namis & Dwarf Shrew \\
\hline Sorex preblei & Preble's Shrew \\
\hline Spermophilus armatus & Uinta Ground Squirrel \\
\hline Spermophilus elegans & Wyoming Ground Squirrel \\
\hline Spilogale gracilis & Western Spotted Skunk \\
\hline Thomomys idahoensis & Idaho Pocket Gopher \\
\hline Ursus arctos & Grizzly Bear \\
\hline \multicolumn{2}{|l|}{ Invertebrates } \\
\hline Agapetus montamus & An Agapetus Caddisfly \\
\hline
\end{tabular}




\begin{tabular}{|c|c|}
\hline Caenis youngi & A Mayfly \\
\hline Euphudruas gillettii & Gillette`s Checkerspot \\
\hline Margaritifera falcata & Western Pearlshell \\
\hline \multicolumn{2}{|l|}{ Lichens } \\
\hline Rhizoplaca handenii & Wamderlust Lichen \\
\hline \multicolumn{2}{|l|}{ Plants } \\
\hline Agastache cusickii & Cusick's Giant-hyssop \\
\hline Amaranthus californicus & California Amaranth \\
\hline Aquilegia formosa & Crimson Columbine \\
\hline Astragalus ceramicus var. apus & Painted Milk-vetch \\
\hline Astragalus comvallarius & Timber Milk-vetch \\
\hline Astragalus leptaleus & Park Milk-vetclı \\
\hline Astragalus scaphoides & Bitterroot Milk-vetch \\
\hline Astragalus terminalis & Railhead Milk-vetch \\
\hline Atriplex truncata & Wedge-leaved Saltbush \\
\hline Balsamorliza hookeri & Hooker's Balsamroot \\
\hline Balsamorhiza macroplyylla & Cut-leaf Balsamroot \\
\hline Braya linmilis & Low Braya \\
\hline Calochortus bruneaunis & Bruneau Mariposa Lily \\
\hline Carex idahoa & Idaho Sedge \\
\hline Carex multicostata & Many-ribbed Sedge \\
\hline Carex norvegica ssp. stevenii & Scandinavian Sedge \\
\hline Castilleja crista-galli & Greater Red Indian-paintbrush \\
\hline Castilleja nivea & Snow Indian-paintbrush \\
\hline Clinysothanunus parryi ssp. montantus & Parry`s Rabbitbrush \\
\hline Cryptantha fendleri & Fendler's Cat's-eye \\
\hline Cryptantha lnumilis & Round-spike Cat's-eye \\
\hline Delphinium bicolor ssp. calcicola & Flat-head Larkspur \\
\hline Delphinium glaucescens & Electric Peak Larkspur \\
\hline Downingia laeta & Great Basin Downingia \\
\hline Draba densifolia & Denseleaf Whitlow-grass \\
\hline Draba globosa & Rockcress Draba \\
\hline Elatine americana & American Waterwort \\
\hline Elymus flavescens & Sand Wildrye \\
\hline Erigeron asperugineus & ]daho Fleabane \\
\hline Erigeron gracilis & Slender Fleabane \\
\hline Erigeron leiomerils & Smooth Fleabane \\
\hline Erigeron linearis & Linearleaf Fleabane \\
\hline Erigeron parryi & Parry`s fleabane \\
\hline Erigeron tener & Tender Fleabane \\
\hline Eriogonum caespitosum & Matted Wild Buckwheat \\
\hline
\end{tabular}




\begin{tabular}{|c|c|}
\hline Eriogonum soliceps & Railroad Canyon Wild Buckwheat \\
\hline Eupatorium occidentale & Western Joepye-weed \\
\hline Gentiana fremontii & Moss Gentian \\
\hline Gentianopsis simplex & One-flower Gentian \\
\hline Hutchinsia procumbens & Prostrate Hymenolobus \\
\hline Ipomopsis congesta ssp. crebrifolia & Compact Gilia \\
\hline Kobresia simpliciuscula & Simple Kobresia \\
\hline Kochia americana & Perennial Summer-cypress \\
\hline Lomatium attemuatum & Taper-tip Desert-parsley \\
\hline Lomatogonium rotatum & Marsh Felwort \\
\hline Oenothera pallida var. idahoensis & Pale Evening-primrose \\
\hline Orogenia linearifolia & Great Basin Indian-potato \\
\hline Oxytropis parryi & Parry's Crazyweed \\
\hline Pedicularis contorta var. ctenophora & Coil-beaked Lousewort \\
\hline Pedicularis cremulata & Scallop-leaf Lousewort \\
\hline Penstemon lemhiensis & Lemhi Beardtongue \\
\hline Penstemon whippleamus & Whipple`s Beardtongue \\
\hline Phacelia incana & Western Phacelia \\
\hline Plysaria pulchella & Beautiful Bladderpod \\
\hline Plagiobothrys leptocladus & Alkali Popcorn-flower \\
\hline Potentilla plattensis & Platte River Cinquefoil \\
\hline Primula alcalina & Alkali Primrose \\
\hline Primula incona & Jones Primrose \\
\hline Puccinellia lemmonii & Lemmon's Alkali Grass \\
\hline Ramunculus jovis & Hillside Buttercup \\
\hline Silene repens & Creeping Catchfly \\
\hline Sphaeralcea mumroana & White-stem Globemallow \\
\hline Sphaeromeria argentea & Nuttall's False Sagebrush \\
\hline Stellaria crassifolia & Fleshy Stitchwort \\
\hline Stellaria jamesiana & Sticky False-starwort \\
\hline Stipa lettermanii & Letterman's Needlegrass \\
\hline Taraxacum eriophorum & Wool-bearing Dandelion \\
\hline Thalictrum alpimum & Alpine Meadowrue \\
\hline Thelypodimm paniculatum & Northwestern Thelypody \\
\hline Thelypodinm sagittatnm & Slender Thelypody \\
\hline Thlaspi parviflorum & Small-flowered Pennycress \\
\hline Townsendia florifera & Showy Townsend-daisy \\
\hline Townsendia spathulata & Sword Townsendia \\
\hline Viguiera multiflora & Many-flower Viguiera \\
\hline
\end{tabular}




\section{APPENDIX B. MTNHP RAPID ECOLOGICAL INTEGRITY}

\section{Assessment Forms}





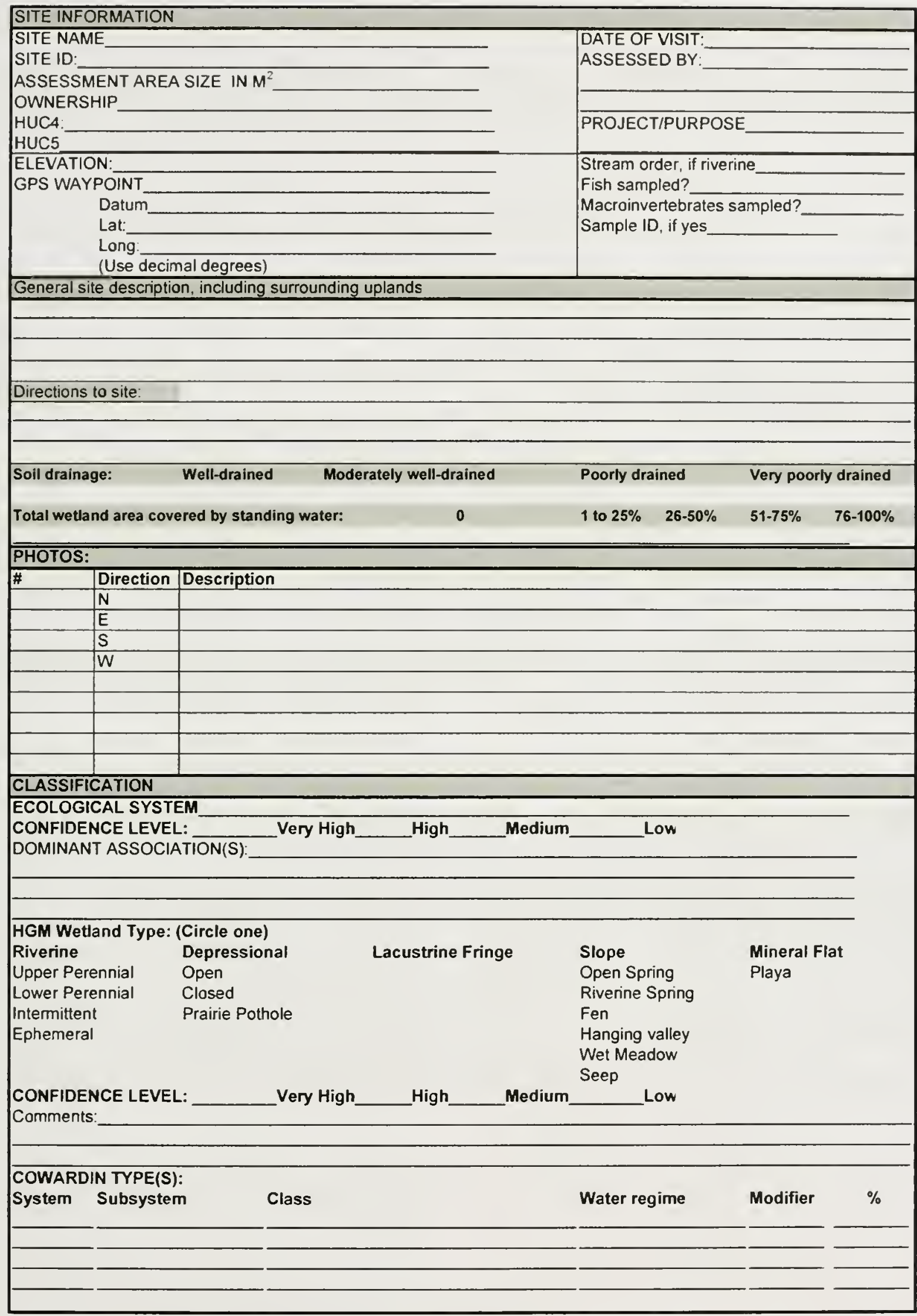


Site Name

LEVEL II ASSESSMENT--Marshes, wet meadows, potholes

Site ID

\begin{tabular}{|c|c|c|c|c|c|}
\hline METRIC & EXCELLENT(A) & GOOD(B) & FAIR (C) & POOR(D) & SCORE \\
\hline \multicolumn{6}{|l|}{ LANDSCAPE CONTEXT } \\
\hline \multicolumn{6}{|l|}{ Connectivity } \\
\hline Non-niverine & $\begin{array}{l}90-100 \% \text { natural habitat } \\
\text { within } 500 \mathrm{~m} \text { of wetland } \\
\text { perimeter }\end{array}$ & $\begin{array}{l}60-90 \% \text { natural habital } \\
\text { within } 500 \mathrm{~m} \text { of wetland } \\
\text { penmeter }\end{array}$ & $\begin{array}{l}10-60 \% \text { natural habitat } \\
\text { within } 500 \mathrm{~m} \text { of wetland } \\
\text { perimeter }\end{array}$ & $\begin{array}{l}<10 \% \text { natural habitat within } \\
500 \mathrm{~m} \text { of wetland perimeter }\end{array}$ & \\
\hline Riverine & $\begin{array}{l}90-100 \% \text { natural habitat } \\
\text { within } 500 \mathrm{~m} \text { on either } \\
\text { side and } 500 \mathrm{~m} \\
\text { upstream and } \\
\text { downstream }\end{array}$ & $\begin{array}{l}60-90 \% \text { natural habitat } \\
\text { within } 500 \mathrm{~m} \text { on either } \\
\text { side and } 500 \mathrm{~m} \text { upstream } \\
\text { and downstream }\end{array}$ & $\begin{array}{l}10-60 \% \text { natural habitat } \\
\text { within } 500 \mathrm{~m} \text { on either } \\
\text { side and } 500 \mathrm{~m} \text { upstream } \\
\text { and downstream }\end{array}$ & $\begin{array}{l}<10 \% \text { natural habitat within } \\
500 \mathrm{~m} \text { on either side and } 500 \\
\mathrm{~m} \text { upstream and downstream }\end{array}$ & \\
\hline \multicolumn{6}{|l|}{ Buffer } \\
\hline Length & $\begin{array}{l}\text { Buffer is }>75 \% \text { of } \\
\text { wetland perimeter }\end{array}$ & $\begin{array}{l}\text { Buffer is }>50-75 \% \text { of } \\
\text { wetland perimeter }\end{array}$ & $\begin{array}{l}\text { Buffer is } 25-50 \% \text { of } \\
\text { wetland penmeter }\end{array}$ & $\begin{array}{l}\text { Buffer is }<25 \% \text { of wetland } \\
\text { perimeter }\end{array}$ & \\
\hline Width & $\begin{array}{l}\text { Average buffer width is } \\
>200 \mathrm{~m} \text {, adjusted for } \\
\text { slope }\end{array}$ & $\begin{array}{l}\text { Average buffer width } \\
>100-200 \mathrm{~m} \text {, adjusted for } \\
\text { slope }\end{array}$ & $\begin{array}{l}\text { Average buffer width is } 50 \\
100 \mathrm{~m} \text {, adjusted for slope }\end{array}$ & $\begin{array}{l}\text { Average buffer width is }<50 \\
\mathrm{~m} \text {, adjusted for slope }\end{array}$ & \\
\hline Condition & $\begin{array}{l}\text { Buffer is }>95 \% \text { native } \\
\text { vegetation with intact } \\
\text { soils and little or no } \\
\text { trash or refuse }\end{array}$ & $\begin{array}{l}\text { Buffer is }>75-95 \% \text { native } \\
\text { vegetation with intact or } \\
\text { slightly distrubed soils, } \\
\text { and minor evidence of } \\
\text { human visitation or } \\
\text { recreation }\end{array}$ & $\begin{array}{l}\text { Buffer is }>25-75 \% \text { native } \\
\text { vegetation with slightly to } \\
\text { moderately distrubed } \\
\text { soils, and moderate } \\
\text { human visitation or } \\
\text { recreation }\end{array}$ & $\begin{array}{l}\text { Buffer is }<25 \% \text { native } \\
\text { vegetation with severely } \\
\text { disturbed soils, and } \\
\text { substantial human visitation or } \\
\text { recreation }\end{array}$ & \\
\hline \multicolumn{6}{|l|}{$\overline{\text { SIZE }}$} \\
\hline Relative Patch Size & $\begin{array}{l}\text { Wetland is }>95 \% \text { of } \\
\text { original size }\end{array}$ & $\begin{array}{l}\text { Wetland is }>80-95 \% \text { of } \\
\text { original size }\end{array}$ & $\begin{array}{l}\text { Wetland is } 50-80 \% \text { of } \\
\text { original size }\end{array}$ & $\begin{array}{l}\text { Wetland is }<50 \% \text { of oniginal } \\
\text { size }\end{array}$ & \\
\hline Absolute Patch Size & $\begin{array}{l}\text { Wetland is very large } \\
\text { compared to others of } \\
\text { its type (e.g. top 10\%) }\end{array}$ & $\begin{array}{l}\text { Welland is large com- } \\
\text { pared to others of its type } \\
\text { (e.g., top } 10-30 \% \text { ) }\end{array}$ & $\begin{array}{l}\text { Wetland is average } \\
\text { compared to others of its } \\
\text { type (e.g. } 30-70 \%)\end{array}$ & $\begin{array}{l}\text { Wetland is too small to } \\
\text { sustain full function and } \\
\text { diversity }\end{array}$ & \\
\hline \multicolumn{6}{|c|}{ VEGETATION STRUCTURE (BIOTA) } \\
\hline Structure & \multicolumn{2}{|c|}{$\begin{array}{l}\text { Vegetation at or near reference standard } \\
\text { condition in structural proportions }\end{array}$} & $\begin{array}{l}\text { Vegetation moderately } \\
\text { altered from reference } \\
\text { standard condition in } \\
\text { structural proportions }\end{array}$ & $\begin{array}{l}\text { Vegetation greatly altered } \\
\text { from reference standard } \\
\text { condition in structural } \\
\text { proportions }\end{array}$ & \\
\hline Composition & \multicolumn{2}{|c|}{$\begin{array}{l}\text { Vegetation at or near reference standard } \\
\text { condition in species present and their } \\
\text { proportions. Regeneration good. Full suite of } \\
\text { diagnostic species present. }\end{array}$} & $\begin{array}{l}\text { Vegetation differs from } \\
\text { reference standard } \\
\text { condition but still largely } \\
\text { native. Tolerant or weedy } \\
\text { natives may be present. } \\
\text { Many indicators absent. }\end{array}$ & $\begin{array}{l}\text { Vegetation severely altered } \\
\text { from reference standard } \\
\text { Some strata absent or } \\
\text { dominated by weedy species. } \\
\text { Most indicator species absent }\end{array}$ & \\
\hline $\begin{array}{l}\text { Relative Cover of } \\
\text { Native Plant Species }\end{array}$ & $\begin{array}{l}>99 \% \text { relative cover of } \\
\text { native plants }\end{array}$ & $\begin{array}{l}95-99 \% \text { relative cover of } \\
\text { native plants }\end{array}$ & $\begin{array}{l}80-94 \% \text { relative cover of } \\
\text { native plants }\end{array}$ & $\begin{array}{l}50-79 \% \text { relative cover of } \\
\text { native plants }\end{array}$ & \\
\hline Invasive exotic species & $\begin{array}{l}\text { No key invasive exotic } \\
\text { plants present }\end{array}$ & $\begin{array}{l}<3 \% \text { invasive exotic } \\
\text { plants present }\end{array}$ & $\begin{array}{l}\text { 3-5\% invasive exotic } \\
\text { plants present }\end{array}$ & $\begin{array}{l}>5 \% \text { invasive exotic plants } \\
\text { present }\end{array}$ & \\
\hline $\begin{array}{l}\text { Organic Matter } \\
\text { Accumulation }\end{array}$ & \multicolumn{2}{|c|}{$\begin{array}{l}\text { Site has moderate amount of fine organic } \\
\text { matter. New materials more prevalent than } \\
\text { oid materials. Layers in pools or topographic } \\
\text { lows are thin. }\end{array}$} & $\begin{array}{l}\text { Site is characterized by } \\
\text { small amounts of coarse } \\
\text { organic debris, with little } \\
\text { organic matter } \\
\text { recuritment, OR debris is } \\
\text { somewhat excessive }\end{array}$ & $\begin{array}{l}\text { Site has little coarse debris } \\
\text { and only scant fine debris OR } \\
\text { debris is excessive. }\end{array}$ & \\
\hline
\end{tabular}


Site Name

LEVEL II ASSESSMENT-Marshes, wet meadows, potholes

Site 10

\begin{tabular}{|c|c|c|c|c|c|}
\hline METRIC & EXCELLENT(A) & GOOD(B) & FAIR (C) & POOR(D) & SCORE \\
\hline $\begin{array}{l}\text { Patch Types (See } \\
\text { below) }\end{array}$ & $\begin{array}{l}>7 \text { abrotac/biotic patch } \\
\text { types present in the } \\
\text { wetland (>6 for } \\
\text { potholes) }\end{array}$ & $\begin{array}{l}5 \text { to } 7 \text { abioticfbiotic patch } \\
\text { types present in the } \\
\text { wetland ( } 5 \text { or } 6 \text { for } \\
\text { potholes) }\end{array}$ & $\begin{array}{l}3 \text { or } 4 \text { abiotic/biotic patch } \\
\text { types present in the } \\
\text { wetland }\end{array}$ & $\begin{array}{l}1 \text { or } 2 \text { abiotic/biotic patch } \\
\text { types present }\end{array}$ & \\
\hline Patch Interspersion & $\begin{array}{l}\text { Horizontal structure } \\
\text { consists of a very } \\
\text { complex array of nested } \\
\text { or interspersed irregular } \\
\text { bioticlabiotic patches } \\
\text { with no single dominant } \\
\text { type. }\end{array}$ & $\begin{array}{l}\text { Honzontal structure } \\
\text { consists of a moderately } \\
\text { complex array of nested } \\
\text { or interspersed irregular } \\
\text { bioticlabiotic patches with } \\
\text { no single dominant type }\end{array}$ & $\begin{array}{l}\text { Honzontal structure } \\
\text { consists of a simple array } \\
\text { of nested or interspersed } \\
\text { Irregular bioticlabiotic } \\
\text { patches with no single } \\
\text { dominant type }\end{array}$ & $\begin{array}{l}\text { Horizontal structure consists } \\
\text { of one dominant patch type } \\
\text { with no interspersion }\end{array}$ & \\
\hline \multicolumn{6}{|l|}{ HYOROLOGY } \\
\hline Water Source & $\begin{array}{l}\text { Water source is } \\
\text { precipitation, } \\
\text { groundwater, natural } \\
\text { runoff OR system } \\
\text { naturally lacks water } \\
\text { during growing season } \\
\text { No indication of direct } \\
\text { artifical water source or } \\
\text { point source discharge }\end{array}$ & $\begin{array}{l}\text { Water source is mostly } \\
\text { natural, but site receives } \\
\text { occasional or small } \\
\text { amounts of inflow from } \\
\text { human sources e.9, road } \\
\text { runoff, storm drains, } \\
\text { imigation). No large point } \\
\text { source discharge into } \\
\text { site }\end{array}$ & $\begin{array}{l}\text { Water source is primarily } \\
\text { runoff, imgation, pumped } \\
\text { water, impounded water, } \\
\text { or other artificia! } \\
\text { hydrology. Major point } \\
\text { sources discharging into } \\
\text { wetland may be present. }\end{array}$ & $\begin{array}{l}\text { Water flow has been } \\
\text { substantially dimınıshed by } \\
\text { Impoundments, diversions, or } \\
\text { withdrawals from wetland or } \\
\text { adjacent areas OR the water } \\
\text { source is so altered that } \\
\text { wetland vegetation is gone. }\end{array}$ & \\
\hline Hydroperiod & $\begin{array}{l}\text { Hydroperiod is } \\
\text { characterized by natural } \\
\text { periods of } \\
\text { filling/inundation and } \\
\text { drawing down. }\end{array}$ & $\begin{array}{l}\text { Filling or inundation is } \\
\text { greater and of greater or } \\
\text { lesser duration than } \\
\text { under natural conditions, } \\
\text { but the site is subject to } \\
\text { natural drying }\end{array}$ & $\begin{array}{l}\text { Filling or inundation is } \\
\text { natural, but drawdown } \\
\text { and drying more rapid, } \\
\text { OR filling/inundation is of } \\
\text { lower than natural } \\
\text { magnitude or duration, } \\
\text { but site is subject to } \\
\text { natural drying. }\end{array}$ & $\begin{array}{l}\text { Filling or inundation and } \\
\text { drawdown/drying both deviate } \\
\text { from natural regimes. }\end{array}$ & \\
\hline $\begin{array}{l}\text { Hydrologic } \\
\text { Connectivity }\end{array}$ & $\begin{array}{l}\text { Rising water in site has } \\
\text { unrestricted access to } \\
\text { adjacent upland, without } \\
\text { levees, excessively high } \\
\text { banks, artificial bamers, } \\
\text { or other obstructions to } \\
\text { lateral movement of } \\
\text { flood flows. }\end{array}$ & $\begin{array}{l}\text { Rising water has partially } \\
\text { restricted }(<50 \%) \text { access } \\
\text { to upland due to } \\
\text { unnatural features OR } \\
\text { flood drainage back into } \\
\text { wetland is incomplete due } \\
\text { to impoundments or } \\
\text { bamers. }\end{array}$ & $\begin{array}{l}\text { Risıng water has } \\
\text { signıficantly restricted ( } 50 \\
90 \% \text { ) access to upland } \\
\text { due to unnatural features. }\end{array}$ & $\begin{array}{l}\text { All water stages in the wetland } \\
\text { are contained by artifical } \\
\text { banks, levees, walls, or berms } \\
\text { or }>90 \% \text { of wetland has } \\
\text { barners to drainage. There is } \\
\text { essentially no hydrologic } \\
\text { connection to uplands }\end{array}$ & \\
\hline \multicolumn{6}{|l|}{ PHYSIOCHEMICAL } \\
\hline Soil Surface Integrity & $\begin{array}{l}\text { Bare soil areas are } \\
\text { limited to naturally } \\
\text { caused disturbances } \\
\text { such as flood deposition } \\
\text { or game trails. }\end{array}$ & $\begin{array}{l}\text { Bare soil due to human } \\
\text { impacts is present but } \\
\text { minimal. Water is not } \\
\text { ponding or channelled }\end{array}$ & $\begin{array}{l}\text { Unnatural areas of bare } \\
\text { soil are common. Ponding } \\
\text { or channeling may be } \\
\text { present in shallow } \\
\text { disturbances. }\end{array}$ & $\begin{array}{l}\text { Unnatural areas of bare soil } \\
\text { are extensive and ponding or } \\
\text { channeling is likely. Surface } \\
\text { disturbances are deep and } \\
\text { widespread. }\end{array}$ & \\
\hline Water Quality & $\begin{array}{l}\text { Water is clear with no } \\
\text { sheen, scum, or hint of } \\
\text { green. Plants that } \\
\text { respond to enrichment } \\
\text { are minimally present or } \\
\text { absent. }\end{array}$ & $\begin{array}{l}\text { Water has a minimal } \\
\text { greenish tint, cloudiness, } \\
\text { or sheen. Plants that } \\
\text { respond to ennichment } \\
\text { ore present but not } \\
\text { dominant. }\end{array}$ & $\begin{array}{l}\text { Water has a moderate } \\
\text { greenish tint, sheen, or } \\
\text { turbidity with common } \\
\text { algae. Plants that } \\
\text { respond to enrichment } \\
\text { are common. }\end{array}$ & $\begin{array}{l}\text { Water has a strong greenish } \\
\text { tint, sheen, or turbidity } \\
\text { Surface algal mats or other } \\
\text { vegetation block light to the } \\
\text { bottom. }\end{array}$ & \\
\hline \multirow[t]{11}{*}{ Patch types: } & Lacustrine Fringe & Pothole & Slope & Flat & \\
\hline & Open water-stream & Open water & Open water-stream & Open water & \\
\hline & Oxbow/backwater & Shallow emergent & Oxbow/backwater & Mud/salt flat & \\
\hline & Secondary channel & Salıne meadow & Secondary channel & Salt flat & \\
\hline & Deep emergent plants & Hummocks or mounds & Deep emergent plants & Deep emergent plants & \\
\hline & Shallow emergent plants & Submerged or floating & Shallow emergent plants & Shallow emergent plants & \\
\hline & Beaver dam & Transitional meadow & Hummocks or mounds & Saline meadows & \\
\hline & Trees & Tall emergent & Shrubs & Greasewood & \\
\hline & Shrubs & & Spnngsisoeps & Hummocks or mounds & \\
\hline & Springs/seeps & & Submerged/floatıng veg & Submerged or floating vegetation & \\
\hline & Subrnerged/fioating veg & & Transitional meadow & & \\
\hline
\end{tabular}


Site Name

Site ID

STRESSORS

Land use within $300 \mathrm{~m}$ of wetland edge

Percent land use

Urban residential

Industrial/commercial

Military/airport

Dryland farming

Crop agriculture

Orchards/nurseries

Logging operation/timber removal

Feedlot

Dairy

Enclosed livestock grazing

Open range grazing

Sports field or park

Active recreation (OHV, mountain biking, shooting)

Resource extraction

Recent fire ( $<5$ years)

Boating (motorized)

Transportation with $500 \mathrm{~m}$ of wetland edge

Distance from edge

Lightly travelled road

Moderately travelled road

Heavily travelled road

Pedestrian trail

Horse trail

Railroad

Land use within site

Mowing

Livestock grazing

Excessive herbivory

Excessive human visitation

Tree cutting/sapling removal

Pesticide or herbicide application

Recent fire ( $<5$ years)

Recent flood

Invasive animals or plants

Hydrology within $300 \mathrm{~m}$

Point source discharge

Non-point source discharge

Flow diversion or unnatural inflow

Dams

Flow obstructions

Weirs, headgates

Dredged inlet or channel

Engineered channel

Dike/levee

Groundwater pumping

Ditches

Soil disturbance witin $300 \mathrm{~m}$

Filling or dumping

Grading/compaction/roadwork

Plowing or discing

Logging or clearing

Unnatural areas of bare soil

Trash or refuse

Pugging, hummocking, or erosion

\begin{tabular}{|l|}
\hline Percent land use \\
\hline \\
\hline \\
\hline \\
\hline \\
\hline \\
\hline \\
\hline \\
\hline \\
\hline \\
\hline
\end{tabular}

Appendix B-A 


\section{LEVEL III ASSESSMENT--Marshes, wet meadows, potholes}

\section{Procedure:}

1. In each inundation zone, you will identify all species in 151 meter $\times 1 / 2$ meter plots.

a. If there is only 1 inundation zone (e.g., a wet meadow), place the plots in a concentric circle from the middle of the wetland to the outer edge.

b. If there are two inundation zones, pace the circumference (or length) of the outer zone, and divide by 15 to get plot spacing. Then place an additional 15 plots in a concentric circle from the inside edge of the outer zone to the innermost extent of emergent vegetation.

2. In each square plot, identify all plant species and record its cover using the following cover classes:

\begin{tabular}{|lr|}
\hline Range & Class \\
Solitary or few & 1 \\
0 to $1 \%$ & 2 \\
$1-2 \%$ & 3 \\
$2-5 \%$ & 4 \\
$5-10 \%$ & 5 \\
$10-25 \%$ & 6 \\
$25-50 \%$ & 7 \\
$50-75 \%$ & 8 \\
$75-95 \%$ & 9 \\
$95-100 \%$ & 10 \\
\hline
\end{tabular}

3. Draw the approximate shape of the assessment area and the distribution of plots on the aerial photograph, if available. If not, sketch it below. 
SITE ID:
ZONE:

PLOT \#

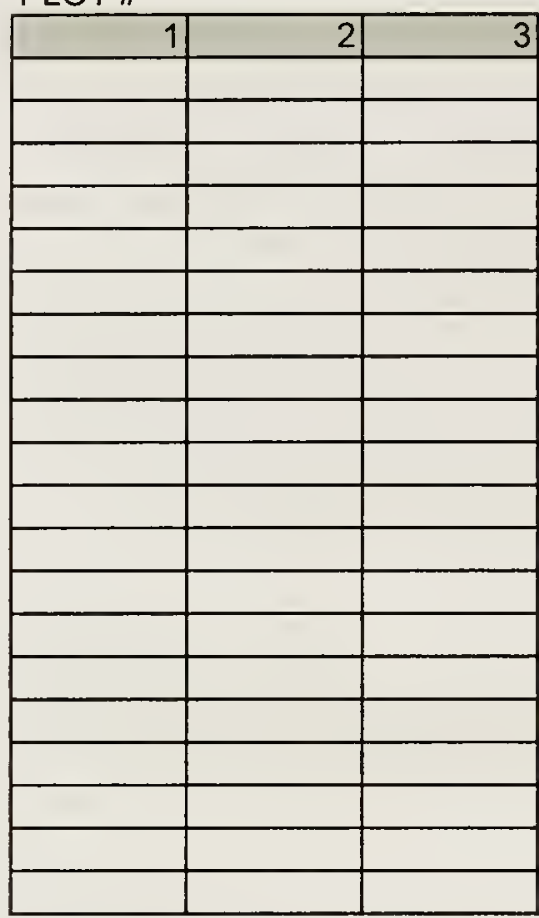

3
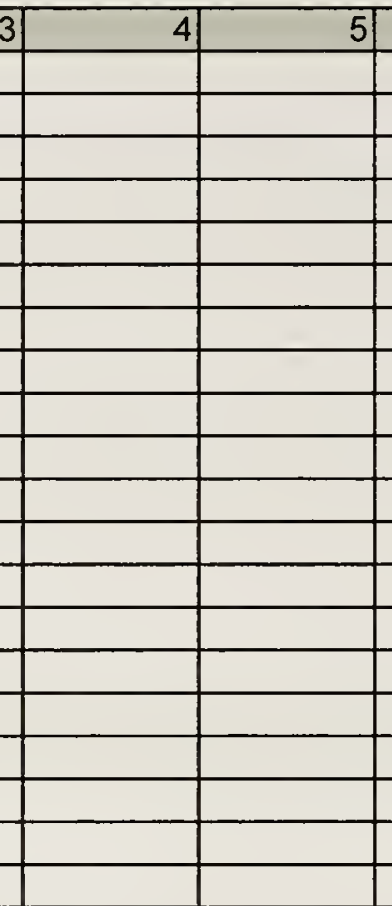

$6 \quad 7$

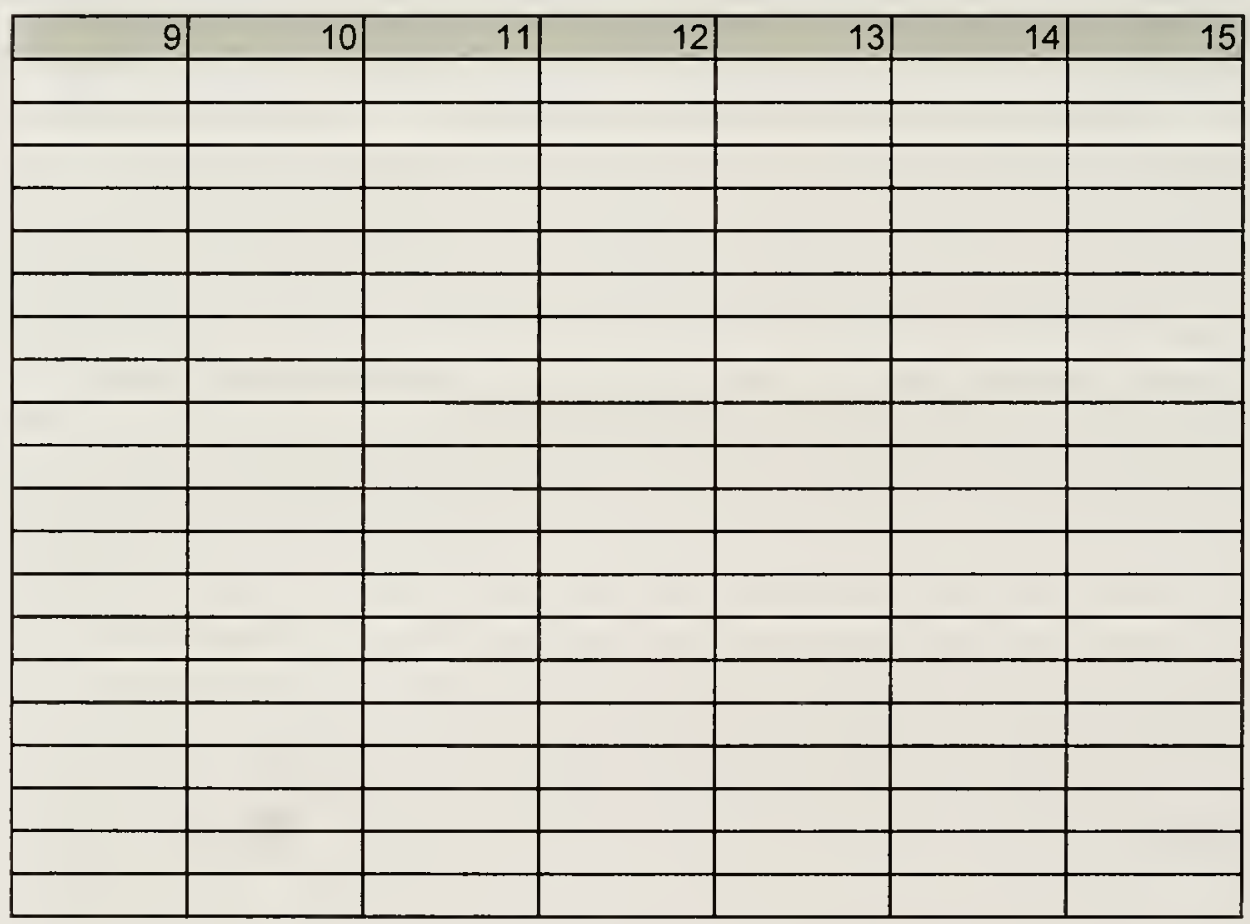

Appendix B - 6 


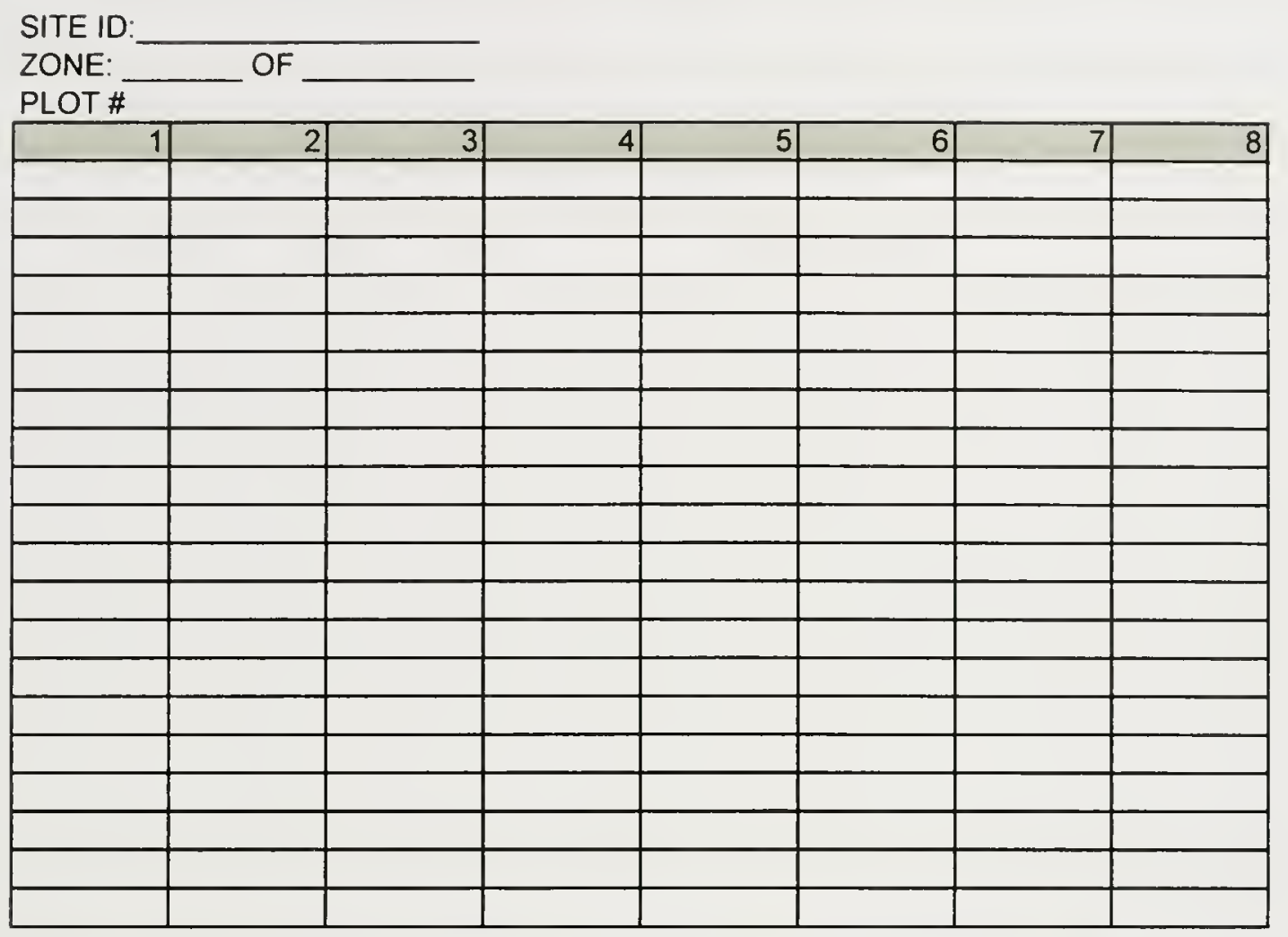

\begin{tabular}{|r|r|r|r|r|r|r|}
\hline 9 & 10 & 11 & 12 & 13 & 14 & 15 \\
\hline & & & & & & \\
\hline & & & & & & \\
\hline & & & & & & \\
\hline & & & & & & \\
\hline & & & & & & \\
\hline & & & & & & \\
\hline & & & & & & \\
\hline & & & & & & \\
\hline & & & & & & \\
\hline & & & & & & \\
\hline & & & & & & \\
\hline & & & & & & \\
\hline & & & & & & \\
\hline & & & & & & \\
\hline & & & & & & \\
\hline
\end{tabular}

Appendix B - 7 

Appendix C-1. Site Information, Wetland Assessments 

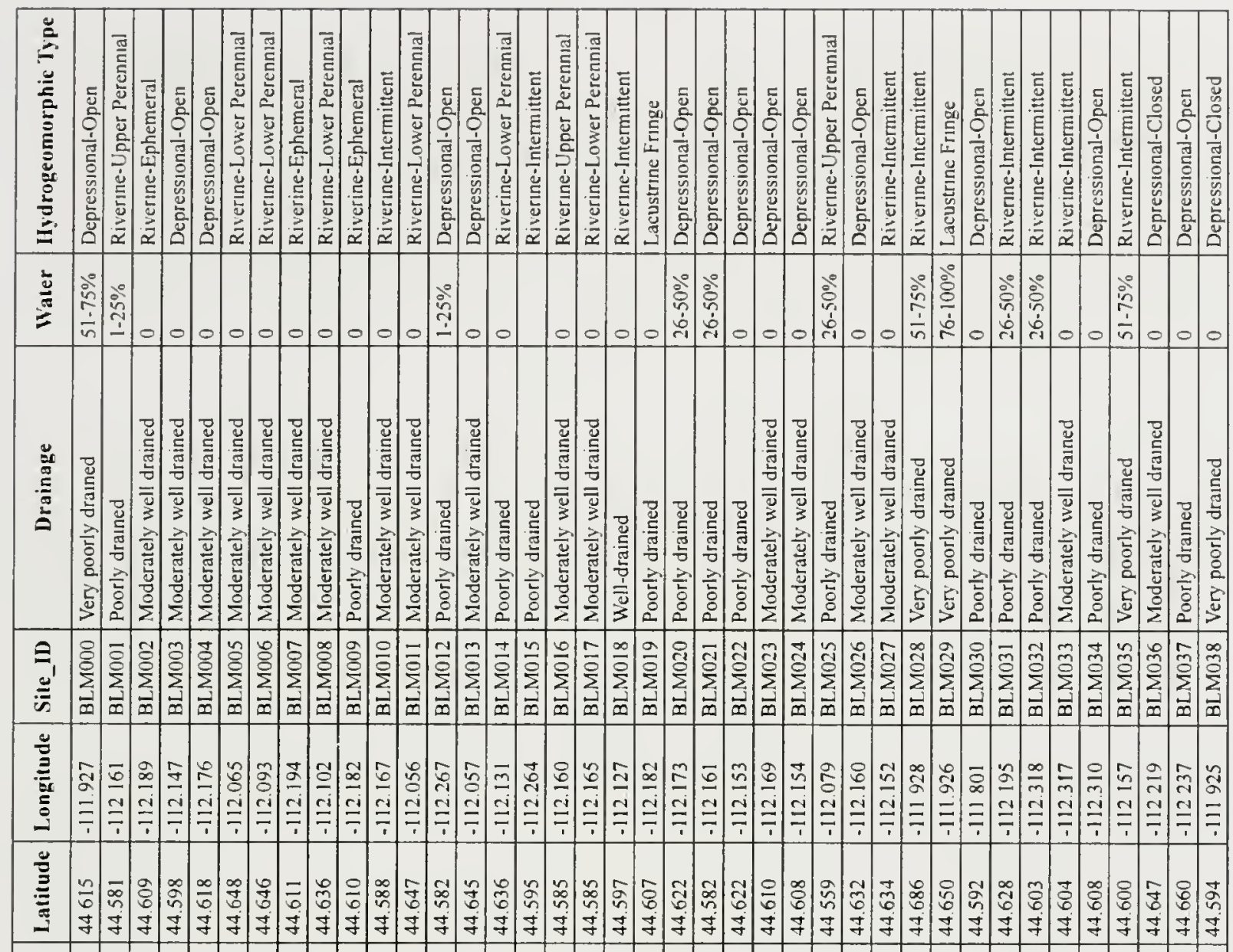

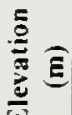

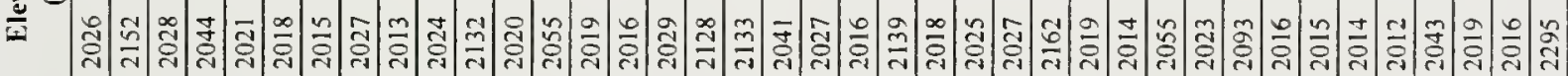

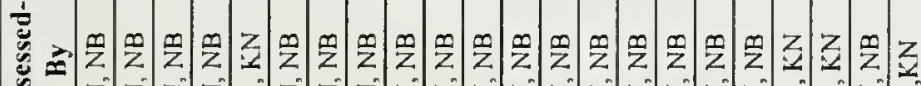

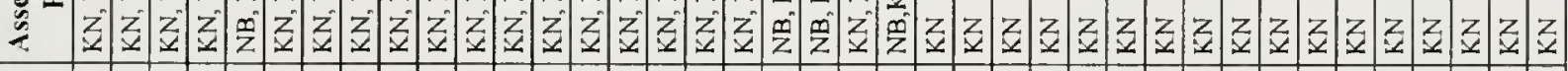

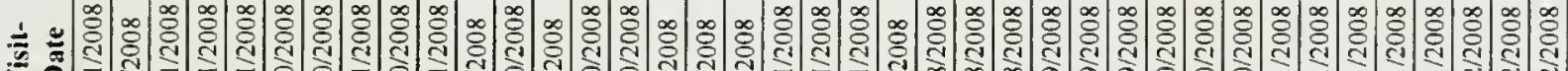

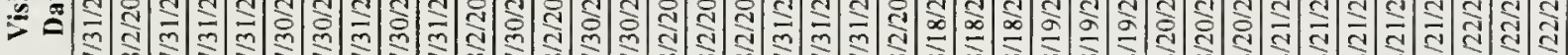

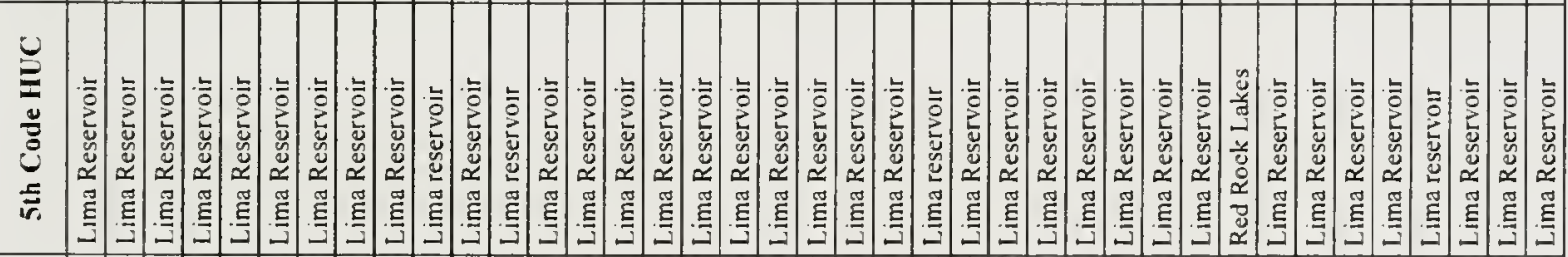

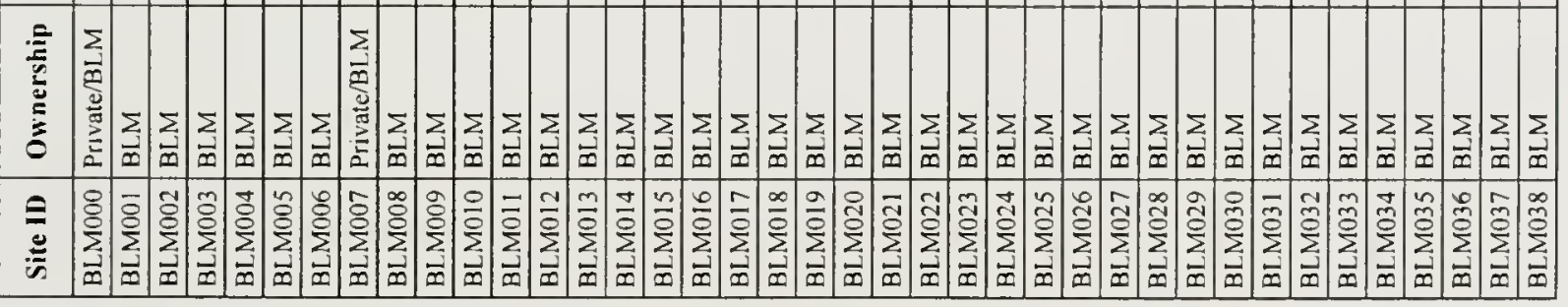




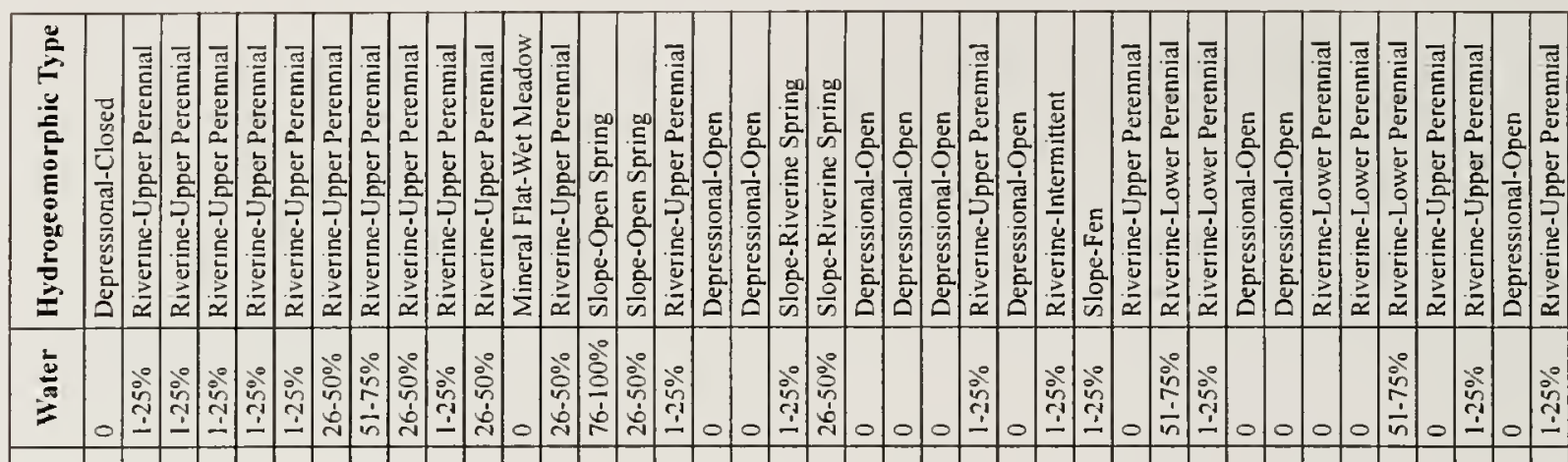

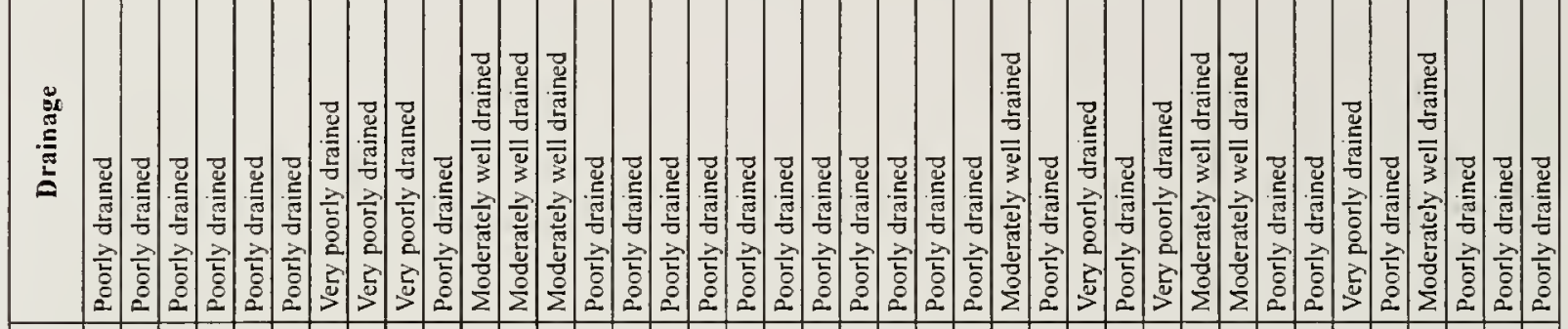

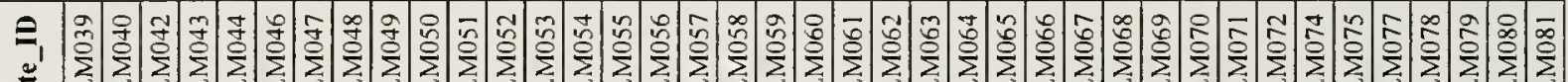

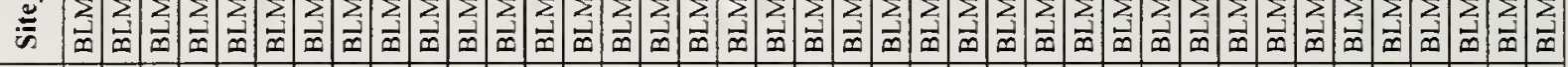

产

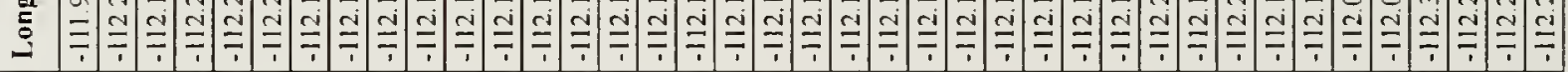

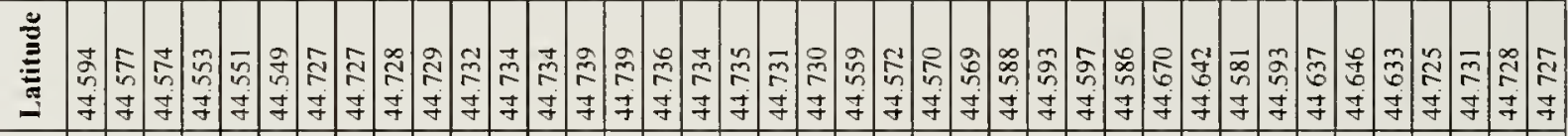

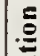

昰

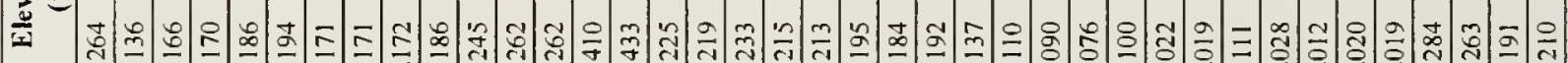

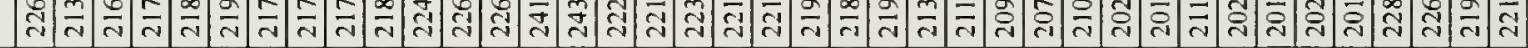

竞

要

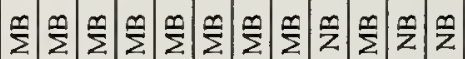

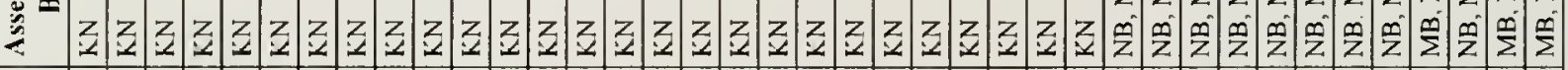

亡

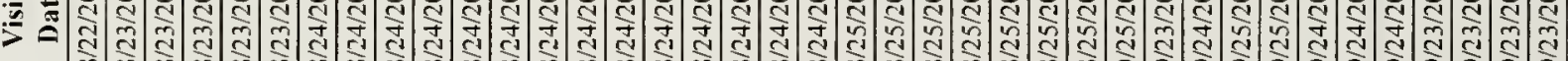

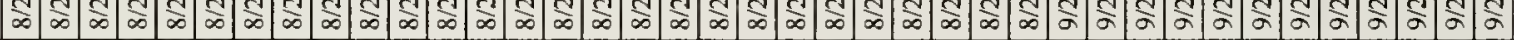

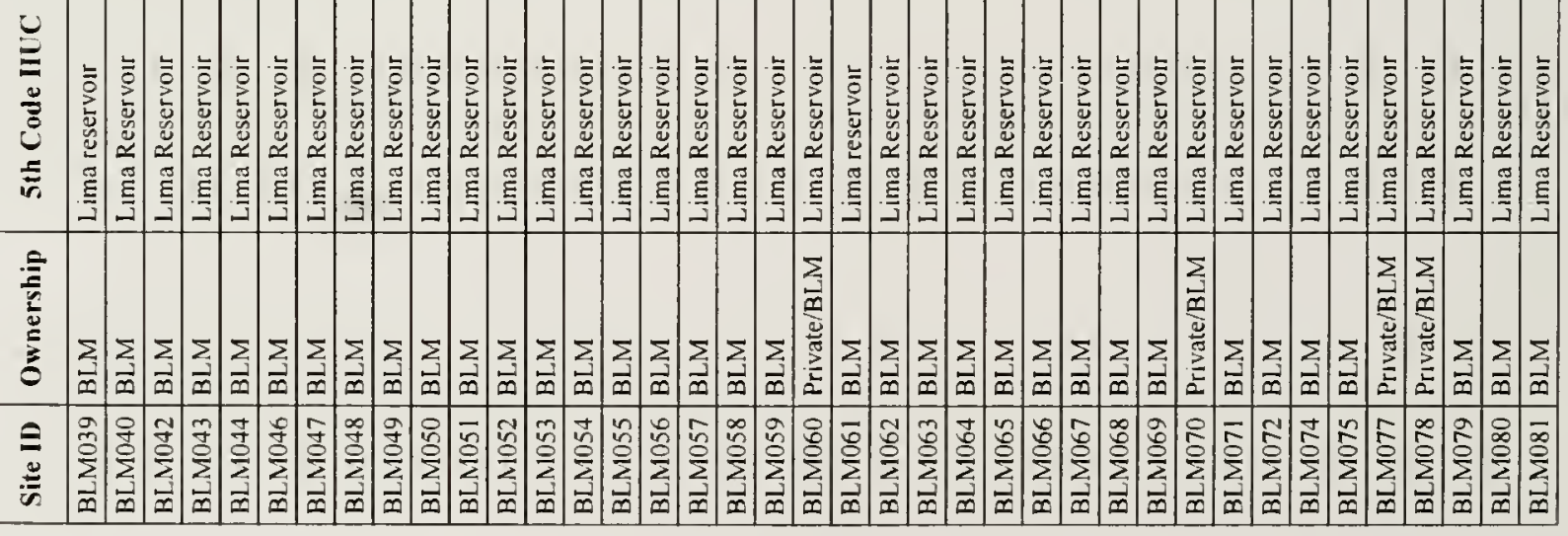

Appendix $C-2$ 


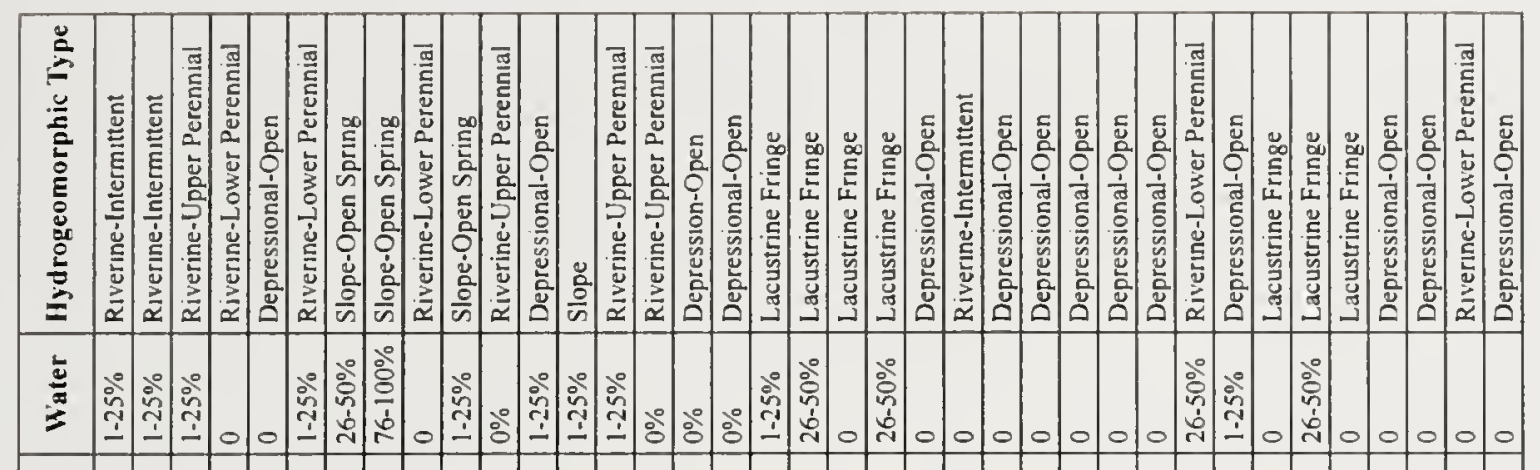

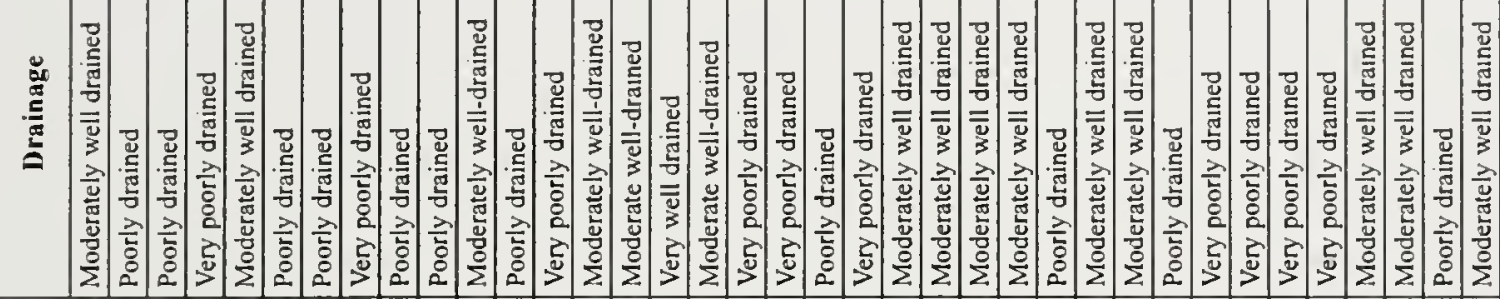

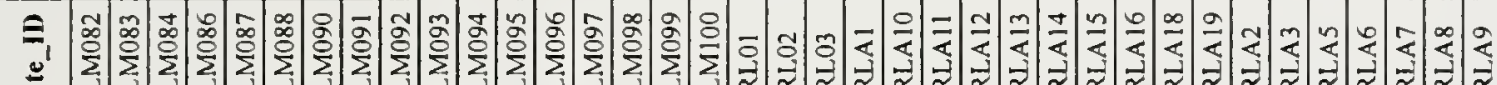

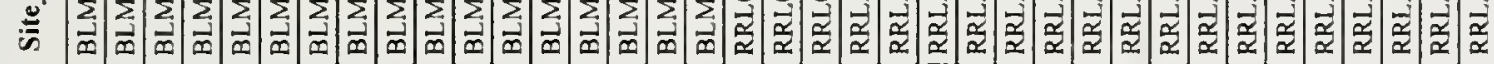

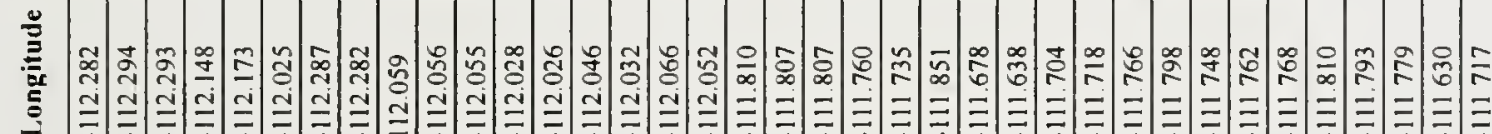

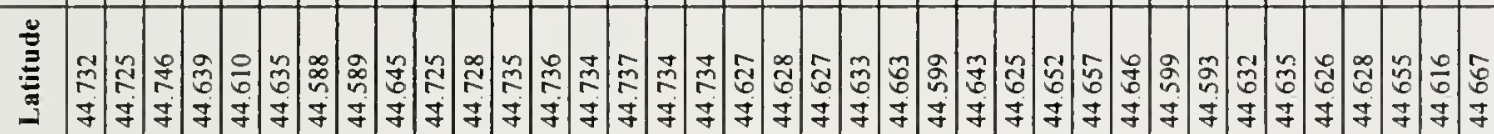

竞

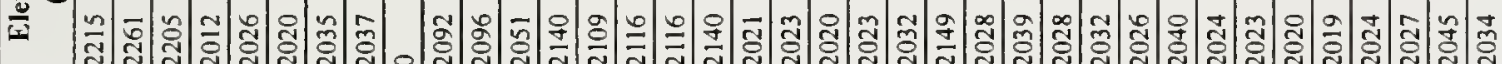

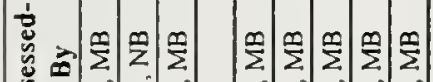

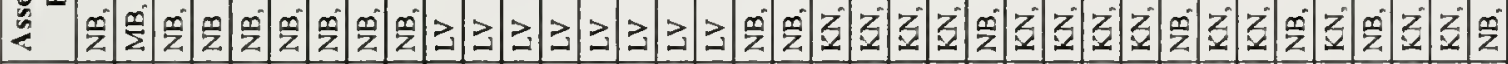
它

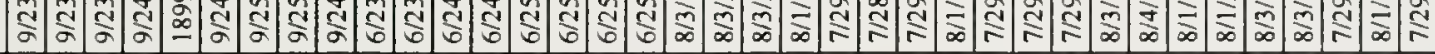

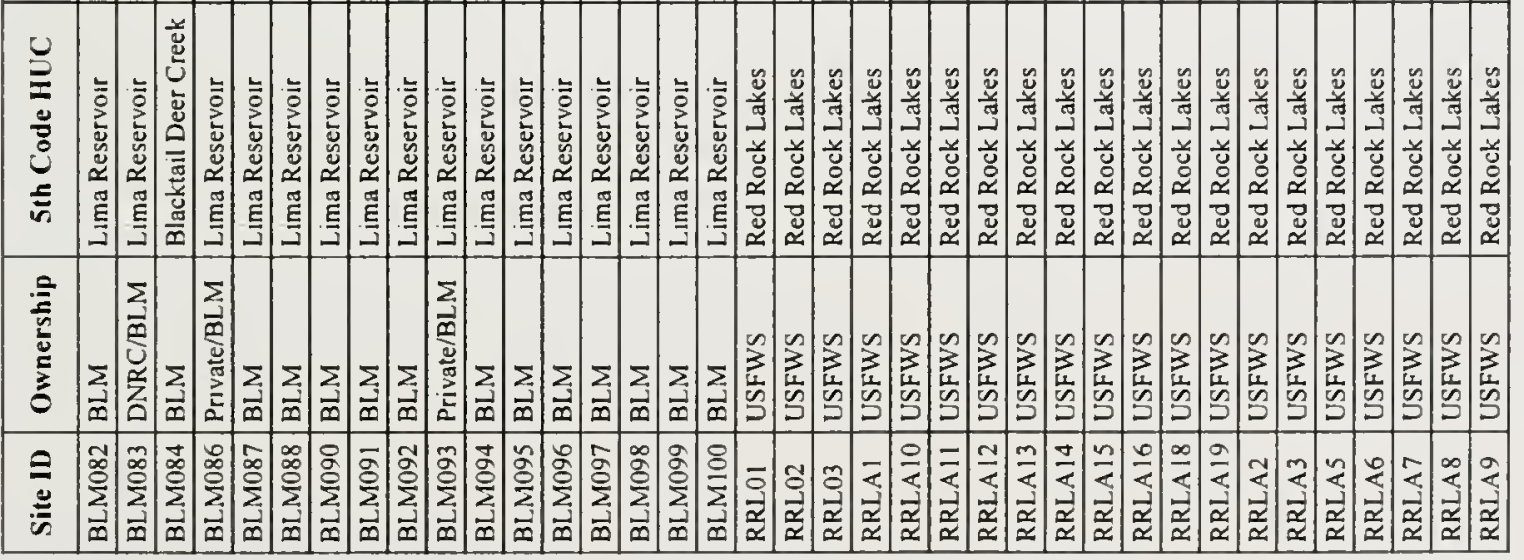




\section{Appendix C-2. PFC and EIA Scores}




\begin{tabular}{|c|c|c|c|c|c|}
\hline SITE ID & $\begin{array}{l}\text { RANKING } \\
(\mathrm{N} / \mathrm{A}=\text { Not } \\
\text { assessed with } \\
\text { this Protocol) }\end{array}$ & $\begin{array}{l}\text { TREND } \\
\text { IF FAR }\end{array}$ & $\begin{array}{c}\text { FACTORS } \\
\text { OUTSIDE BLM } \\
\text { CONTROL? }\end{array}$ & FACTORS & $\begin{array}{l}\text { EIA SCORE } \\
\text { (N/A = Not } \\
\text { assessed with } \\
\text { this Protocol) }\end{array}$ \\
\hline BLM001 & PFC & & & & $B$ \\
\hline BLM002 & PFC & & & & $B$ \\
\hline BLM003 & PFC & & & & $\mathrm{B}$ \\
\hline BLM004 & PFC & & & & $A$ \\
\hline BLM005 & PFC & & & & $\mathrm{A}$ \\
\hline BLM006 & $\mathrm{PFC}$ & & & & $\mathrm{A}$ \\
\hline BLM007 & NF & & & & $\mathrm{B}$ \\
\hline BLM008 & PFC & & & & $\mathrm{A}$ \\
\hline BLM009 & FAR & $\mathrm{D}$ & No & & $\mathrm{B}$ \\
\hline BLM010 & PFC & & & & $\mathrm{A}$ \\
\hline BLM011 & FAR & $\mathrm{D}$ & No & & B \\
\hline BLM012 & PFC & & & & $\mathrm{B}$ \\
\hline BLM013 & FAR & $\mathrm{D}$ & No & & $B$ \\
\hline BLM014 & PFC & & & & $\mathrm{A}$ \\
\hline BLM015 & PFC & & & & $\mathrm{A}$ \\
\hline BLM016 & PFC & & & & $A$ \\
\hline BLM017 & N/A & & & & $\mathrm{A}$ \\
\hline BLM018 & $\mathrm{N} / \mathrm{A}$ & & & & $\mathrm{C}$ \\
\hline BLM019 & FAR & $\mathrm{D}$ & No & & B \\
\hline BLM020 & $\mathrm{PFC}$ & & & & $\mathrm{A}$ \\
\hline BLM02! & PFC & & & & B \\
\hline BLM022 & PFC & & & & $\mathrm{A}$ \\
\hline BLM023 & PFC & & & & $\mathrm{N} / \mathrm{A}$ \\
\hline BLM024 & PFC & & & & $\mathrm{A}$ \\
\hline BLM025 & N/A & & & & $B$ \\
\hline BLM026 & PFC & & & & $\mathrm{C}$ \\
\hline BLM027 & FAR & $\mathrm{D}$ & No & & $\mathrm{B}$ \\
\hline BLM028 & FAR & D & No & & $\mathrm{B}$ \\
\hline BLM029 & PFC & & & & $A$ \\
\hline BLM030 & PFC & & & & B \\
\hline BLM031 & PFC & & & & $\mathrm{A}$ \\
\hline BLM032 & FAR & $\mathrm{D}$ & No & & $B$ \\
\hline RRL03 & PFC & & & & A \\
\hline BLM033 & NF & & & & $\mathrm{B}$ \\
\hline BLM034 & PFC & & & & $\mathrm{N} / \mathrm{A}$ \\
\hline BLM035 & NF & & & & $\mathrm{C}$ \\
\hline BLM036 & PFC & & & & N/A \\
\hline BLM037 & FAR & $\mathrm{D}$ & No & & $\mathrm{N} / \mathrm{A}$ \\
\hline
\end{tabular}

Appendix $C-4$ 


\begin{tabular}{|c|c|c|c|c|c|}
\hline SITE ID & $\begin{array}{l}\text { RANKING } \\
\text { (N/A =Not } \\
\text { assessed with } \\
\text { this Protocol) }\end{array}$ & $\begin{array}{l}\text { TREND } \\
\text { IF FAR }\end{array}$ & $\begin{array}{c}\text { FACTORS } \\
\text { OUTSIDE BLM } \\
\text { CONTROL? }\end{array}$ & FACTORS & $\begin{array}{c}\text { EIA SCORE } \\
\text { (N/A =Not } \\
\text { assessed with } \\
\text { this Protocol) }\end{array}$ \\
\hline BLM038 & $\mathrm{PFC}$ & & & & $\mathrm{B}$ \\
\hline BLM039 & $\mathrm{PFC}$ & & & & $\mathrm{A}$ \\
\hline BLM040 & N/A & & & & $\mathrm{B}$ \\
\hline BLM042 & FAR & $\mathrm{D}$ & No & & $\mathrm{B}$ \\
\hline BLM043 & N/A & & & & $\mathrm{A}$ \\
\hline BLM044 & $\mathrm{N} / \mathrm{A}$ & & & & A \\
\hline BLM046 & N/A & & & & $\mathrm{A}$ \\
\hline BLM047 & FAR & $\mathrm{D}$ & No & & $\mathrm{B}$ \\
\hline BLM048 & N/A & & & & B \\
\hline BLM049 & FAR & $\mathrm{D}$ & No & & B \\
\hline BLM050 & $\mathrm{NF}$ & & & & $\mathrm{C}$ \\
\hline BLM051 & N/A & & & & $\mathrm{A}$ \\
\hline BLM052 & $\mathrm{NF}$ & & & & $\mathrm{C}$ \\
\hline BLM053 & NF & & & & $\mathrm{C}$ \\
\hline BLM054 & PFC & & & & $\mathrm{A}$ \\
\hline BLM055 & $\mathrm{PFC}$ & & & & A \\
\hline BLM056 & N/A & & & & $B$ \\
\hline BLM057 & $\mathrm{PFC}$ & & & & $\mathrm{B}$ \\
\hline BLM058 & FAR & $\mathrm{D}$ & No & & $\mathrm{C}$ \\
\hline BLM059 & N/A & & & & B \\
\hline BLM060 & $N / A$ & & & & $\mathrm{~A}$ \\
\hline BLM061 & $\mathrm{PFC}$ & & & & $\mathrm{A}$ \\
\hline BLM062 & PFC & & & & $\mathrm{N} / \mathrm{A}$ \\
\hline BLM063 & PFC & & & & $\mathrm{N} / \mathrm{A}$ \\
\hline BLM064 & $\mathrm{PFC}$ & & & & $\mathrm{A}$ \\
\hline BLM065 & $\mathrm{NF}$ & & & & $\mathrm{B}$ \\
\hline BLM066 & PFC & & & & $\mathrm{A}$ \\
\hline BLM067 & PFC & & & & $\mathrm{A}$ \\
\hline BLM068 & FAR & UNK & No & & $\mathrm{B}$ \\
\hline BLM069 & $\mathrm{PFC}$ & & & & $\mathrm{A}$ \\
\hline BLM070 & $\mathrm{PFC}$ & & & & $\mathrm{B}$ \\
\hline BLM071 & $\mathrm{PFC}$ & & & & $\mathrm{B}$ \\
\hline BLM072 & FAR & UNK & Yes & Road encroachment & $\mathrm{B}$ \\
\hline BLM074 & PFC & & & & N/A \\
\hline BLM075 & PFC & & & & $\mathrm{A}$ \\
\hline BLM077 & FAR & $\mathrm{D}$ & Yes & Dredging & $\mathrm{B}$ \\
\hline BLM078 & $\mathrm{PFC}$ & & & & $\mathrm{B}$ \\
\hline BLM079 & $\mathrm{PFC}$ & & & & A \\
\hline
\end{tabular}




\begin{tabular}{|c|c|c|c|c|c|}
\hline SITE ID & $\begin{array}{l}\text { RANKING } \\
\text { (N/A = Not } \\
\text { assessed with } \\
\text { this Protocol) }\end{array}$ & $\begin{array}{l}\text { TREND } \\
\text { IF FAR }\end{array}$ & $\begin{array}{c}\text { FACTORS } \\
\text { OUTSIDE BLM } \\
\text { CONTROL? }\end{array}$ & FACTORS & $\begin{array}{l}\text { EIA SCORE } \\
(\mathrm{N} / \mathrm{A}=\text { Not } \\
\text { assessed with } \\
\text { this Protocol) }\end{array}$ \\
\hline BLM080 & FAR & $\mathrm{D}$ & No & & $\mathrm{B}$ \\
\hline BLM081 & $\mathrm{PFC}$ & & & & A \\
\hline BLM082 & $\mathrm{PFC}$ & & & & $\mathrm{B}$ \\
\hline BLM083 & PFC & & & & $\mathrm{A}$ \\
\hline BLM084 & PFC & & & & B \\
\hline BLM086 & PFC & & & & $\mathrm{N} / \mathrm{A}$ \\
\hline BLM087 & $\mathrm{PFC}$ & & & & N/A \\
\hline BLM088 & FAR & UNK & No & & $\mathrm{B}$ \\
\hline BLM090 & FAR & $\mathrm{D}$ & No & & $\mathrm{B}$ \\
\hline BLM091 & PFC & & & & $\mathrm{A}$ \\
\hline BLM092 & PFC & & & & $\mathrm{A}$ \\
\hline BLM093 & FAR & $\mathrm{D}$ & Yes & Private land activities & $\mathrm{C}$ \\
\hline BLM094 & $\mathrm{PFC}$ & & & & $\mathrm{B}$ \\
\hline BLM095 & PFC & & & & $\mathrm{B}$ \\
\hline BLM096 & FAR & $\mathrm{D}$ & No & & $\mathrm{C}$ \\
\hline BLM097 & PFC & & & & $\mathrm{B}$ \\
\hline BLM098 & PFC & & & & $\mathrm{B}$ \\
\hline BLM099 & PFC & & & & $\mathrm{B}$ \\
\hline BLM100 & PFC & & & & B \\
\hline RRLAl & PFC & & & & A \\
\hline RRLA10 & $\mathrm{PFC}$ & & & & $\mathrm{A}$ \\
\hline RRLA11 & PFC & & & & $\mathrm{B}$ \\
\hline RRLA12 & PFC & & & & A \\
\hline RRLA13 & FAR & $\mathrm{D}$ & No & & B \\
\hline RRLA14 & PFC & & & & $\mathrm{A}$ \\
\hline RRLA15 & PFC & & & & $\mathrm{B}$ \\
\hline RRLA16 & PFC & & & & $\mathrm{A}$ \\
\hline RRLA18 & PFC & & & & $\mathrm{B}$ \\
\hline RRLA19 & PFC & & & & $\mathrm{A}$ \\
\hline RRLA2 & PFC & & & & A \\
\hline RRLA3 & PFC & & & & $\mathrm{A}$ \\
\hline RRLA5 & PFC & & & & A \\
\hline RRLA6 & FAR & $\mathrm{D}$ & Yes & Drought & $\mathrm{B}$ \\
\hline RRLA7 & PFC & & & & $\mathrm{A}$ \\
\hline RRLA8 & PFC & & & & A \\
\hline RRLA9 & $\mathrm{PFC}$ & & & & $\mathrm{B}$ \\
\hline RRL01 & PFC & & & & $\mathrm{A}$ \\
\hline RRL02 & PFC & & & & A \\
\hline
\end{tabular}



Appendix C-3. Site Comments 


\begin{tabular}{|c|c|}
\hline Site_ID & Site Description \\
\hline BLM000 & Wetland on edge of small lake \\
\hline BLM001 & Wetland is site of former beaver activity, lots of downed wood, some beaver shews evident \\
\hline BLM002 & Site overgrazed wet meadow \\
\hline BLM003 & Wet meadow \\
\hline BLM004 & Site is wet. meadow in drainage \\
\hline BLM005 & Wet meadow along river \\
\hline BLM006 & Wet meadow adjacent to stream channel \\
\hline BLM007 & Meadow \\
\hline BLM008 & Wet meadow adjacent to Red Rock River \\
\hline BLM009 & $\begin{array}{l}\text { Heavily grazed, site } \mathrm{N} \text { side of Mud Lake, severe pugging, erosion of north shore likely } \\
\text { restricts water from upland }\end{array}$ \\
\hline BLM010 & Wet meadow along intermittent stream \\
\hline BLM011 & Wet meadow has severe liummocking \\
\hline BLM012 & Small mesic meadow influenced by the road, weedy, meadow fed by at least one stream \\
\hline BLM013 & Wet meadow with severe hummocking \\
\hline BLM014 & Wetland part of Red Rock River floodplain \\
\hline BLM015 & Mesic meadow, follows intermittent stream, channel was flowing \\
\hline BLM016 & Wet meadow adjacent to perennial stream \\
\hline BLM017 & Small, flowing perennial stream \\
\hline BLM018 & Dry stream channel, an intermittent trib. of Price Creek, blocked by some sort of diversion \\
\hline BLM019 & Heavily grazed, wetland adjacent to Mud Lake \\
\hline BLM020 & $\begin{array}{l}\text { Large wetland, } 1.5 \mathrm{~km} \text { NE of Mud Lake, connected to Mud Lake hydrologically, high water } \\
\text { in past spring }\end{array}$ \\
\hline BLM021 & Site is old beaver pond, with dam to the N. \\
\hline BLM022 & Meadow connected hydrologically to Sand Creek/Mud Lake \\
\hline BLM023 & Western portion is more of a wet meadow veg. \\
\hline BLM024 & Meadow very hummocked, no true hydrophytes present \\
\hline BLM025 & Site along Peet Creek, weedy, old 2-track road to the W \\
\hline BLM026 & Wetland is a small depression, very few hydrophytes \\
\hline BLM027 & Drainage of Red Rock River \\
\hline BLM028 & $\begin{array}{l}\text { Wet meadow has standing water, cows present and have been loafing in water, severe pug- } \\
\text { ging }\end{array}$ \\
\hline BLM029 & Narrow transitional meadow \\
\hline BLM030 & Wetland small depression, likely receives most of its water from surface run-off \\
\hline \multicolumn{2}{|l|}{ BLM031 } \\
\hline BLM032 & $\begin{array}{l}\text { Wetland part of large depression-wet meadow with standing water at } W \text { end, adjacent to } \\
\text { drainage }\end{array}$ \\
\hline BLM033 & $\begin{array}{l}\text { Wetland is intermittent stream S of Lima Reservoir, severe hummocking has allowed for } \\
\text { ARTCAN establishment }\end{array}$ \\
\hline BLM034 & Wetland is dried mudflat just S of large "slough" $\mathrm{S}$ of Lima Reservoir \\
\hline BLM035 & Wetland part of intermittent stream, cattle loaf in water \\
\hline
\end{tabular}




\begin{tabular}{|c|c|}
\hline Site_ID & Site Description \\
\hline \multicolumn{2}{|l|}{ BLM036 } \\
\hline BLM037 & Wetland is small pond $\mathrm{S}$ of Shineberger Creek, $\mathrm{N}$ of Lima Reservoir \\
\hline BLM038 & Wetland is small pond-wilderness study area \\
\hline BLM039 & Wetland is small pond in wilderness study area \\
\hline BLM040 & Site is Corral Creek \\
\hline BLM042 & Heavily grazed and very weedy \\
\hline BLM043 & Site is along Corral Creek \\
\hline BLM044 & Corral Creek \\
\hline BLM046 & Corral Creek \\
\hline BLM047 & $\begin{array}{l}\text { Wetland is on a trib. of Wolverine Creek, may have been a beaver pond, severe pugging and } \\
\text { hummocking from cows }\end{array}$ \\
\hline BLM048 & $\begin{array}{l}\text { Evidence of very old beaver chews, entire area may have been influenced by beaver, but no } \\
\text { current signs }\end{array}$ \\
\hline BLM049 & $\begin{array}{l}\text { Wetland along trib. of Wolverine Creek, severe pugging and hummocking from cows, may } \\
\text { have been beaver pond long ago }\end{array}$ \\
\hline BLM050 & $\begin{array}{l}\text { Wetland along trib. of Wolverine Creek, site is drying 2-track on W side limiting the stream, } \\
\text { no true channel }\end{array}$ \\
\hline BLM051 & Site along West Creek, signs of old beaver activity \\
\hline BLM052 & Site is historic wet meadow, but likely not flooded during season \\
\hline BLM053 & $\begin{array}{l}\text { Upper end of West Creek. site may have been old beaver pond, but has not been inundated } \\
\text { for years, willows heavily browsed with no regen., site is heavily grazed }\end{array}$ \\
\hline BLM054 & $\begin{array}{l}\text { Small pond created by beaver, beaver dam not active, watersource spring from intermittent } \\
\text { stream. }\end{array}$ \\
\hline BLM055 & Along West Creek \\
\hline BLM056 & $\begin{array}{l}\text { Site is a section in Middle Creek, 2-track rd. through site, veg. heavily grazed, cutbanks } \\
\text { severe }\end{array}$ \\
\hline BLM057 & Small wet meadow on $\mathrm{S}$ side of fence line \\
\hline BLM058 & Small toe-slope wetland, severely hummocked and degraded by cattle and 2-track rd. \\
\hline BLM059 & Site is small toe-slope, spring-fed drainage \\
\hline BLM060 & Did not cross fence \\
\hline BLM061 & \\
\hline BLM062 & Wetland is in forked drainage, sodic soils \\
\hline BLM063 & Wetland is small depression. sodic soils \\
\hline BLM064 & Site is small drainage, signs of cattle-trails and hummocking \\
\hline BLM065 & Small toe-slope wetland, .75 miles to $\mathrm{S}$ of southside of Centennial $\mathrm{Rd}$. \\
\hline BLM066 & Small intermittent stream $\backslash$ \\
\hline BLM067 & Site is along intermittent stream. lots of moss \\
\hline BLM068 & $\begin{array}{l}\text { Depressional wetland, part of site excavated to create cattle pond-pond is pugged and } \\
\text { mostly bare, berm to } \mathrm{N} \text { of site restricting most water outflow }\end{array}$ \\
\hline BLM069 & Depressional wetland, stream running through site. grazed, hummocking. \\
\hline BLM070 & Wet meadow bordering Red Rock River, weedy, grazed \\
\hline
\end{tabular}




\begin{tabular}{|c|c|}
\hline Site_II & Site Deseription \\
\hline BLM071 & Open depression N of S. Centennial Rd.. weedy, good interspersion, hummocking. grazed \\
\hline BLM072 & $\begin{array}{l}\text { Depressional wetland along S. Centennial Rd.. deep hummocking seems to cause water } \\
\text { pooling/channeling, culvert present under rd. }\end{array}$ \\
\hline BLM074 & $\begin{array}{l}\text { Floodplain adjacent to Red Rock River, inundated temporarily, dry by Sept., pugged by } \\
\text { cattle }\end{array}$ \\
\hline BLM075 & Oxbow of Red Rock River, grazed, luummocking deep in site and buffer \\
\hline BLM077 & $\begin{array}{l}\text { Recently dredged, moved soil spread and compacted along outer channel perimeter, severe- } \\
\text { ly grazed, channel pugged by cattle, hummocking present }\end{array}$ \\
\hline BLM078 & Stream adjacent, grazed, grasses trampled and flattened \\
\hline BLM079 & Stream in valley atop hills, emergents growing $0-5 \mathrm{~m}$ away from stream \\
\hline BLM080 & $\begin{array}{l}\text { Wet meadow on slope of hill, medium hummocking, grazed, area probably saturated in } \\
\text { spring, though not currently }\end{array}$ \\
\hline BLM081 & $\begin{array}{l}\text { Stream wetland between two hills, good diversity, but hummocking in/around stream caus- } \\
\text { ing altered water flow patterns, grazed }\end{array}$ \\
\hline BLM082 & $\begin{array}{l}\text { Wet meadow, stream on W edge of site maintains good wetland indicator plant diversity, } \\
\text { grazed }\end{array}$ \\
\hline BLM083 & Hummocking present along stream and downhill area, grazed \\
\hline BLM084 & Rd. along $\mathrm{N}$ side of site \\
\hline BLM086 & Large floodplain. probably mostly inundated earlier in the year, saline indicators present \\
\hline BLM087 & $\begin{array}{l}\text { Open depression more of a transitional meadow/mesic wet meadow, hummocking present } \\
\text { and may be worse due to cattle }\end{array}$ \\
\hline BLM088 & Heavily grazed, severe hummocking in and adjacent to site \\
\hline BLM090 & $\begin{array}{l}\text { Spring stream at base of southern hills feeds site, opens into valley with aquatic bed and } \\
\text { emergent veg, grazed, hummocking present }\end{array}$ \\
\hline BLM09। & $\begin{array}{l}\text { Open depression wetland, surrounded by dry, hummocked upland ( } 40-50 \% \text { bare ground), } \\
\text { water present in Sept., lots of mass growing among hummocks, water flows out to S. }\end{array}$ \\
\hline BLM092 & $\begin{array}{l}\text { Oxbow of Red Rock River. Pugging/hummocking extensive in some areas. Good intersper- } \\
\text { sion. }\end{array}$ \\
\hline BLM093 & $\begin{array}{l}\text { Slope wetland with peat formation; area immediately east of fence lias been destroyed by } \\
\text { cattle. Adjacent area denuded, deeply hummocked. Probably affecting hydrology in site. }\end{array}$ \\
\hline BLM094 & $\begin{array}{l}\text { Good mesic/wet meadow on floodplain of Long Creek; grazing minimal but corrals nearby. } \\
\text { Soils undisturbed. Some redox features suggest periodic high water tables. }\end{array}$ \\
\hline BLM095 & $\begin{array}{l}\text { Appears to be drying; some soil saturation, considerable redox evidence and areas of deep } \\
\text { organic matter. Cattle trails in and out but little pugging. }\end{array}$ \\
\hline BLM096 & $\begin{array}{l}\text { Saturated soils and peat formation, amphibian breeding observed, tadpoles evident. Exten- } \\
\text { sive pugging and hummocking by cattle breaking down structure and draining wetland. }\end{array}$ \\
\hline BLM097 & $\begin{array}{l}\text { Very good riparian/PSS site with dense cover, little evidence of grazing, well-vegetated } \\
\text { banks, considerable structural diversity. Depth to water }<20 " \text {, good hydric indicators }\end{array}$ \\
\hline BLM098 & $\begin{array}{l}\text { Good riparian wet meadow, high plant diversity with lots of FACW, little evidence of graz- } \\
\text { ing except moose, good bank stability and soils. }\end{array}$ \\
\hline BLM099 & $\begin{array}{l}\text { Wet meadow in small depression. Multiple seeps in area. Soils loamy clay. Gleying evident } \\
\text { in pit; seasonally flooded depression in mesic uplands. }\end{array}$ \\
\hline
\end{tabular}




\begin{tabular}{|c|l|}
\hline Site_ID & Site Description \\
\hline BLM100 & $\begin{array}{l}\text { Wet meadow in depression amidst alluvial fans. Lightly grazed in 2007. Soils undisturbed. } \\
\text { Plant community indicates more grazing in past years. }\end{array}$ \\
\hline RRL01 & Extensive marsh SE of lower Red Rock Lake-small ponds \\
\hline RRL02 & Extensive marsh-small aquatic bed sites \\
\hline RRL03 & Extensive marsh \\
\hline RRLA1 & Extensive CARUTR marsh \\
\hline RRLA10 & Large wet meadow N of upper Red Rock Lake, N of large ditch \\
\hline RRLA11 & $\begin{array}{l}\text { Oped forest, small intermittent stream, cattle present, weedy, old earthen berm to form cattle } \\
\text { pond no longer functioning }\end{array}$ \\
\hline RRLA12 & Large wet meadow N of upper Red Rock Lake \\
\hline RRLA13 & "South Tucks Pond"- Ducks Unlimited "enhancement" project, rarely holds water \\
\hline RRLA14 & Small depression surrounded by wet meadow \\
\hline RRLA15 & $\begin{array}{l}\text { Wet meadow on south side of "Pintail Ditch"- heavily grazed by cattle this year (very re- } \\
\text { cent, within past 2 weeks), lots of moss }\end{array}$ \\
\hline RRLA16 & Large wet meadow \\
\hline RRLA18 & Odell Creek \\
\hline RRLA19 & Artificial pond \\
\hline RRLA2 & Drier end of marsh. mesic meadow within 20m \\
\hline RRLA3 & Extensive marsh border the Red Rock Lakes system, small pond within marsh \\
\hline RRLA5 & Extensive marsh, Boreal chorus frogs everywhere, small pond within marsh \\
\hline RRLA6 & Mesic wet meadow \\
\hline RRLA7 & $\begin{array}{l}\text { Wet meadow, plant spp. associated with cattle grazing. Natural hummocking pres- } \\
\text { ent, plus some due to livestock grazing. }\end{array}$ \\
\hline RRLA8 & Riparian area-wet meadow, very weedy \\
\hline RRLA9 & Small wet meadow site adjacent to Centennial Sandhills \\
\hline
\end{tabular}


Appendix D. Species Richness at BLM Sites 



\begin{tabular}{|c|c|c|c|}
\hline SitelD & $\begin{array}{l}\text { Number } \\
\text { of Species }\end{array}$ & SiteID & $\begin{array}{l}\text { Number } \\
\text { of Species }\end{array}$ \\
\hline BLM000 & 4 & BLM039 & 12 \\
\hline BLM001 & 32 & BLM040 & 14 \\
\hline BLM002 & 17 & BLM042 & 8 \\
\hline BLM003 & 15 & BLM043 & 19 \\
\hline BLM004 & 16 & BLM044 & 15 \\
\hline BLM005 & 26 & BLM046 & 13 \\
\hline BLM006 & 25 & BLM047 & 3 \\
\hline BLM007 & 11 & BLM048 & 8 \\
\hline BLM008 & 26 & BLM049 & 7 \\
\hline BLM009 & 8 & BLM050 & 6 \\
\hline BLM010 & 32 & BLM051 & 4 \\
\hline BLM011 & 15 & BLM052 & 10 \\
\hline BLM012 & 28 & BLM053 & 7 \\
\hline BLM013 & 18 & BLM054 & 3 \\
\hline BLM014 & 24 & BLM055 & 26 \\
\hline BLM015 & 39 & BLM056 & 11 \\
\hline BLM016 & 28 & BLM057 & 10 \\
\hline BLM017 & 34 & BLM058 & 6 \\
\hline BLM018 & 12 & BLM059 & 5 \\
\hline BLM019 & 29 & BLM060 & 9 \\
\hline BLM020 & 7 & BLM061 & 17 \\
\hline BLM021 & 21 & BLM062 & 11 \\
\hline BLM022 & 11 & BLM063 & 12 \\
\hline BLM023 & 18 & BLM064 & 15 \\
\hline BLM024 & 9 & BLM065 & 5 \\
\hline BLM025 & 41 & BLM066 & 10 \\
\hline BLM026 & 10 & BLM067 & 9 \\
\hline BLM027 & 22 & BLM068 & 7 \\
\hline BLM028 & 9 & BLM069 & 11 \\
\hline BLM029 & 10 & BLM070 & 15 \\
\hline BLM030 & 10 & BLM071 & 18 \\
\hline BLM031 & 8 & BLM072 & 17 \\
\hline BLM032 & 14 & BLM073 & 5 \\
\hline BLM033 & 7 & BLM074 & 11 \\
\hline BLM034 & 2 & BLM075 & 11 \\
\hline BLM035 & 5 & BLM077 & 8 \\
\hline BLM036 & 3 & BLM078 & 14 \\
\hline BLM037 & 5 & BLM079 & 13 \\
\hline BLM038 & 7 & BLM080 & 9 \\
\hline
\end{tabular}

Appendix D - I 


\begin{tabular}{|l|c|c|c|c|}
\hline SiteID & $\begin{array}{c}\text { Number } \\
\text { of Species }\end{array}$ & & SiteID & $\begin{array}{c}\text { Number } \\
\text { of Species }\end{array}$ \\
\hline BLM081 & 13 & & BLM092 & 16 \\
\hline BLM082 & 17 & & BLM093 & 24 \\
\hline BLM083 & 20 & & BLM094 & 19 \\
\hline BLM084 & 26 & & BLM095 & 22 \\
\hline BLM086 & 23 & & BLM096 & 18 \\
\hline BLM087 & 11 & & BLM097 & 29 \\
\hline BLM088 & 12 & & BLM098 & 24 \\
\hline BLM090 & 20 & & BLM099 & 22 \\
\hline BLM091 & 12 & & BLM100 & 18 \\
\hline
\end{tabular}



